\title{
Myeloid cell-specific ablation of the mineralocorticoid receptor attenuates experimental autoimmune encephalomyelitis
}

\author{
Dissertation \\ for the award of the degree "Doctor rerum naturalium (Dr. rer. Nat.)" \\ Division of Mathematics and Natural Sciences of the \\ Georg-August University Göttigen \\ submitted by \\ Xiao Li \\ born in \\ Nanjing, Jiangsu, VR China
}

Göttingen, 2012 
Thesis Supervisor:

Prof. Dr. Holger M. Reichardt

Doctoral Committee:

Prof. Dr. Holger M. Reichardt

( $1^{\text {st }}$ Referee)

Cellular and molecular Immunology

University of Göttingen Medical School

Prof. Dr. Lutz Walter

$\left(2^{\text {nd }}\right.$ Referee $)$

Abteilung Primatengenetik

Deutsches Primatenzentrum

Prof. Dr. Steven A. Johnsen

Molecular Oncology

University of Göttingen Medical School 


\section{Declaration}

I hereby declare that I have written this PhD thesis entitled "Myeloid cell-specific ablation of the mineralocorticoid receptor attenuates experimental autoimmune encephalomyelitis" independently and with no other sources and aids than quoted. This thesis has not been submitted elsewhere for any academic degree.

Xiao Li

October 2012

Göttingen, Germany 


\section{List of abbreviations}

\begin{tabular}{|c|c|c|c|}
\hline APC & Antigen presenting cell & BMDM & $\begin{array}{l}\text { Bone marrow derived } \\
\text { macrophage }\end{array}$ \\
\hline dex & Dexamethasone & PM & Peritoneal macrophge \\
\hline EAE & $\begin{array}{c}\text { Experimental } \\
\text { autoimmune } \\
\text { encephalomyelitis }\end{array}$ & TNF & Tumour necrosis factor \\
\hline ELISA & $\begin{array}{c}\text { Enzyme-linked } \\
\text { immunosorbent assay }\end{array}$ & FBS & Fetal bovine serum \\
\hline GC & Glucocorticoid & siRNA & Small interference RNA \\
\hline GR & Glucocorticoid receptor & RNA & Ribonucleic acid \\
\hline \multirow[t]{2}{*}{ MC } & Mineralocorticoid & shRNA & Small hairpin RNA \\
\hline & Mineralocorticoid & & \\
\hline MR & receptor & DNA & Deoxyribonucleic acid \\
\hline MR & LysM-Cre MR flox/flox $^{\text {flo }}$ & PPAR & $\begin{array}{c}\text { Peroxisome } \\
\text { proliferator-activated } \\
\text { receptor }\end{array}$ \\
\hline NO & Nitric oxide & PMA & $\begin{array}{c}\text { Phorbol 12-myristate } \\
\text { 13-acetate }\end{array}$ \\
\hline RT & room temperature & & \\
\hline
\end{tabular}




\section{Prefixes \& Units}

$\begin{array}{llll}\mathbf{k} & \text { kilo } & \text { I } & \text { liter } \\ \mathbf{C} & \text { centi } & \text { M } & \text { molar } \\ \mathbf{m} & \text { milli } & \mathbf{g} & \text { gram } \\ \mathbf{\mu} & \text { micro } & \text { bp } & \text { base-pair } \\ \mathbf{n} & \text { nano } & \text { Da } & \text { dalton } \\ \mathbf{p} & \text { pico } & \mathbf{s} & \text { second } \\ \mathbf{U} & \text { unit } & \mathbf{g} & \text { acceleration of gravity } \\ \mathbf{c m} & \text { centi meter } & \text { V } & \text { volt } \\ \mathbf{h} & \text { hour } & & \\ \mathbf{S} & \text { second } & \text { min } & \text { minute } \\ & & & \end{array}$




\section{Abstract}

The mineralocorticoid receptor (MR) plays an essential role in regulating fluid and electrolyte homeostasis. Amongst hematopoietic cells, also macrophages express the MR but, unlike kidney or colon, they do not co-express the enzyme $11 \beta$-hydroxysteroid dehydrogenase type II (11ß-HSDII). Consequently, glucocorticoids (GC) in macrophages are able not only to activate the GC receptor (GR) but also the MR, and the balance between both effects determines macrophage fate. It had been hypothesized that the absence of the MR induces polarization towards alternatively activated macrophages (AAM), which are known to have anti-inflammatory and wound-healing features. The aim of this study was to obtain further insight into the role of the MR in macrophage polarization and its effects on neuroinflammation in vivo.

This work shows that MR knockout macrophages are skewed towards an AAM phenotype. However, these AAMs have different characteristics compared to those induced by IL-4 and IL-13. In vitro, MR knockout macrophages are characterized by reduced iNOS and increase in Arginase 1 expression. This is supported by in vivo results obtained by inducing experimental autoimmune encephalomyelitis (EAE) mimicking multiple sclerosis (MS) in $\mathrm{MR}^{\text {lysMcre }}$ and $M R^{\text {floxflox }}$ mice. In this disease model, the mutant mice suffer significantly less from EAE than control mice. Macrophages both from the spinal cord and the peritoneal cavity of diseased MR ${ }^{\text {lysMcre }}$ mice show a polarization towards the AAM phenotype. Histological analysis of $M^{\text {lysMcre }}$ mice suffering from $E A E$ confirmed that the pathophysiological features were less severe compared to control mice. Thus, ablation of the MR in macrophages induces their polarization towards AAM thereby ameliorating EAE.

Since MR disruption from early development on may induce compensatory mechanisms, new transgenic mice should be developed allowing for an inducible and reversible deletion of the MR in the hematopoietic system. To this end lentiviral vectors for the inactivation of the MR by RNA interference 
were successfully developed and tested. They were produced at high titers, injected into fertilized mouse oocytes and transgenic offspring was identified that had integrated the new vector. In the future, this new model should become instrumental in analyzing the role of the MR in the control of the immune system. 
Table of contents

1 Introduction 1

$1.1 \quad$ Mineralocorticoid receptor (MR) ..........................................

1.1.1 Steroid hormone-receptor superfamily ............................. 1

1.1.2 Transcriptional Mechanisms ..........................................2

1.1.3 Molecular features of MR ................................................

1.1.4 Physiological functions of MR and its role in the immune

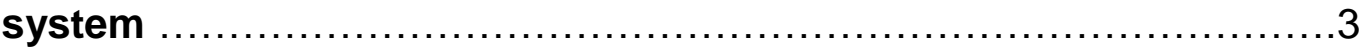

1.1.5 Physiological functions of Glucocorticoid receptor (GR) and its role in the immune system ............................................. 4

1.1.6 Regulation of steroid hormone-receptors by Sirt1...............6

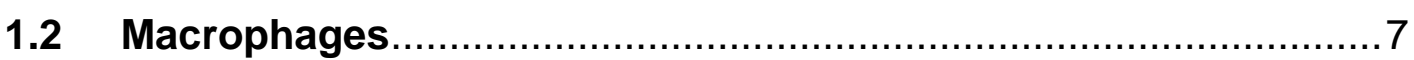

1.2.1 Classically activated macrophages (CAM) ..................... 8

1.2.2 Alternatively activated macrophages (AAM) .................... 8

1.2.3 Effects of sterocorticoids on the differentiation of

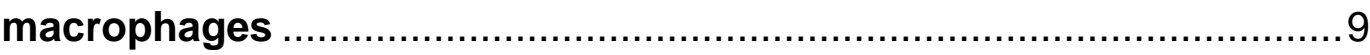

1.2.4 Role of Macrophages in neuroinflammatory diseases ........10

1.3 Multiple sclerosis (MS) and Experimental autoimmune encephalomyelitis (EAE) ........................................................... 11

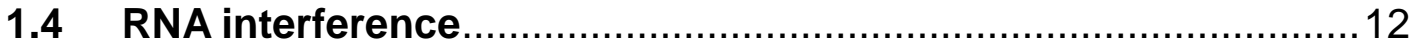

1.4.1 The Mechanisms of RNA interference ............................13

1.4.2 The Inducible and reversible gene knockdown system........14

1.4.3 Lentiviruses and their use as vector systems ................. 15

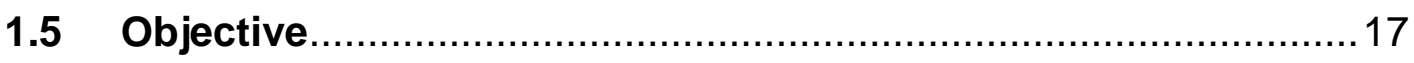

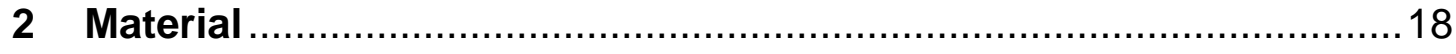

2.1 General equipments ........................................................... 18

2.2 Consumables ....................................................................... 19

2.3 Chemicals and buffers ....................................................... 19

2.4 Media and solutions ......................................................... 21

2.5 List of Antibodies used in flow cytometry (FACS) and western

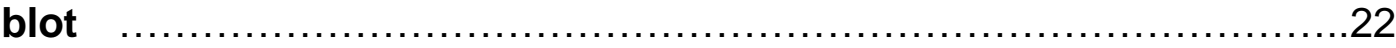

2.5.1 FACS antibodies .......................................................... 22

2.5.2 Western blot antibodies ................................................. 22

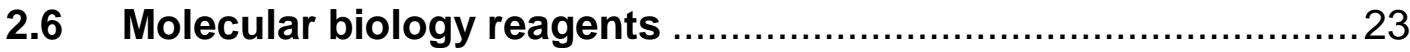




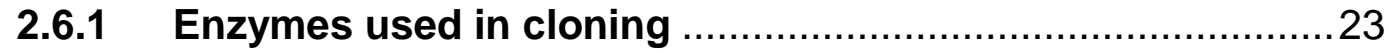

2.6.2 Primers used for mutagenesis PCR ................................23

2.6.3 Enzyme linked immunosorbant Assay (ELISA) ....................26

2.6.4 Nitric oxide assay (NO assay) ..........................................26

2.6.5 Quantitative polymerase chain reaction (qPCR) .................26

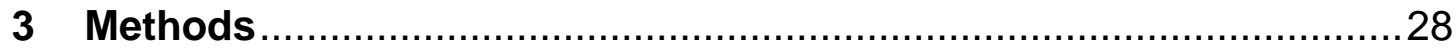

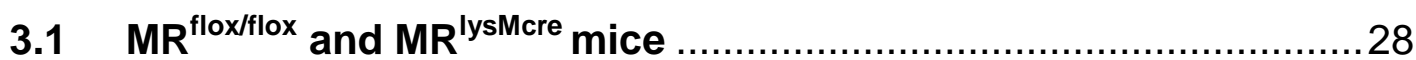

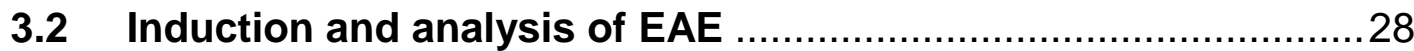

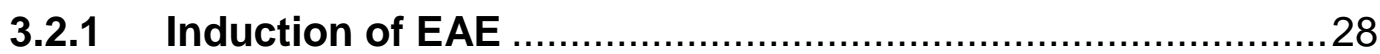

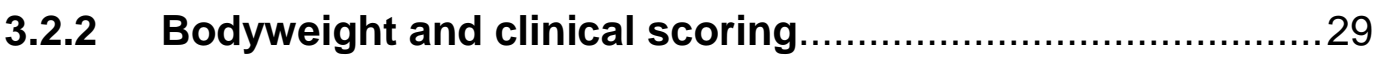

3.2.3 Isolation of spinal cord infiltrating macrophages ................29

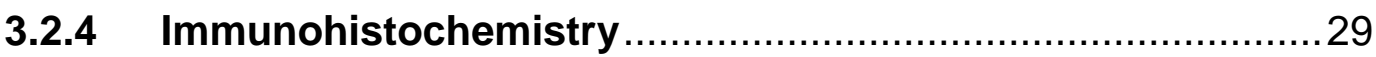

3.3 Isolation of peritoneal macrophages (PM) …….......................30

3.4 Bone marrow derived macrophages (BMDMs) ……..................30

3.4.1 Production of L929-cell conditioned medium (LCCM) .........30

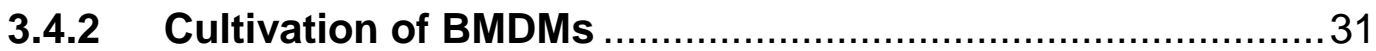

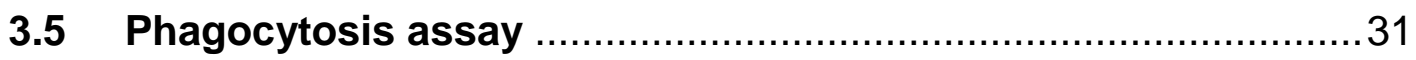

3.6 Quantitative polymerase chain reaction (qPCR) ........................32

3.6.1 Isolation of RNA from cells............................................. 32

3.6.2 Reverse transcription from RNA to cDNA .............................33

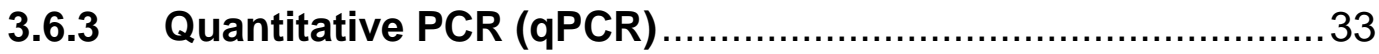

3.7 Enzyme linked immunosorbant Assay (ELISA) ..........................33

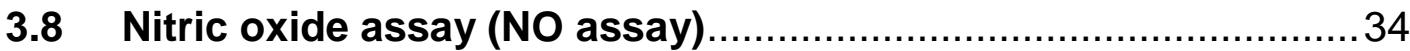

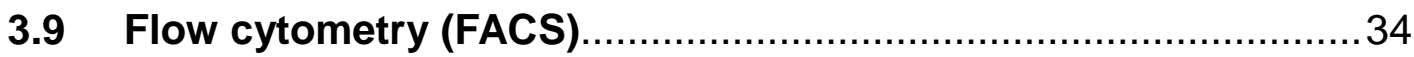

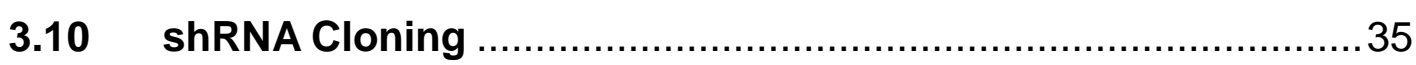

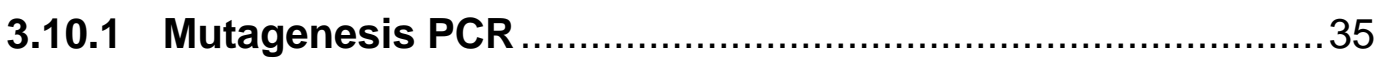

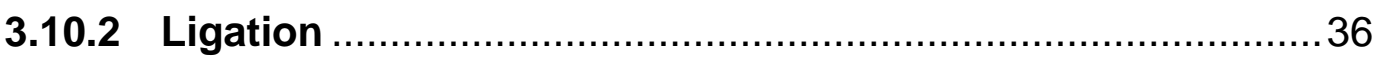

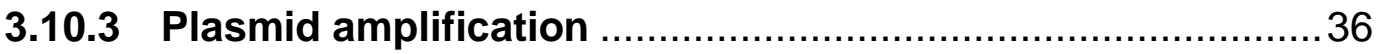

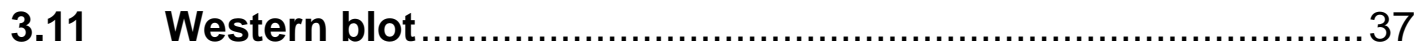

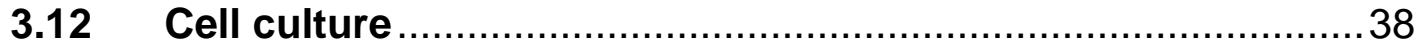

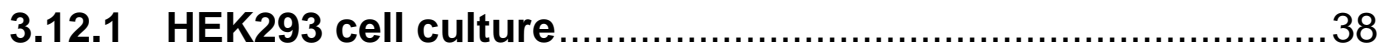

3.12.2 Generation of MR overexpressing cells ...............................38

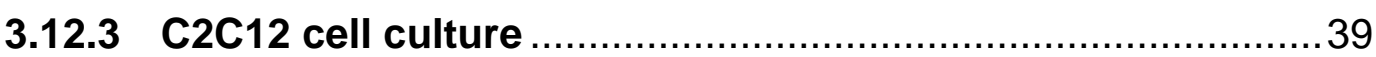

3.12.4 Mouse embryonic fibroblast (MEF) ..................................39 
3.13 Procedures with lentivirus (Under S2 condition) ....................39

3.13.1 Lentivirus production ................................................ 39

3.13.2 Concentrating lentivirus by Ultracentrifugation .................40

3.13.3 Titration ........................................................................... 40

3.13.4 shRNA functional test in vitro ....................................... 41

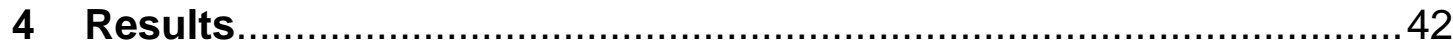

4.1 Characterization of bone marrow derived macrophages (BMDMs)

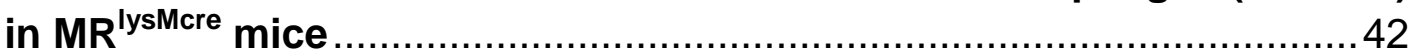

4.1.1 Efficiency of MR ablation in macrophages ...................... 42

4.1.2 Relative expression levels of macrophage-specific genes in

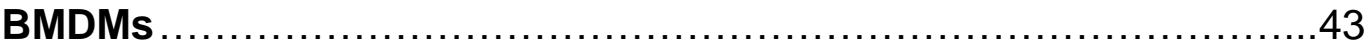

4.1.3 Phagocytosis assay ................................................. 44

4.1.4 TNFa production by BMDMs after LPS stimulation .............45

4.1.5 NO Production by BMDMs after LPS stimulation ................46

4.1.6 Relative gene expression of Arginase1 and iNOS in BMDMs after LPS stimulation .................................................................. 47

4.2 Characterization of peritoneal macrophages (PMs) in MR $^{\text {lysMcre }}$ mice

4.2.1 Relative expression levels of macrophage-specific genes in PMs 48

4.2.2 Phagocytosis assay of PMs ......................................... 49

4.3 Characterization of EAE in MR ${ }^{\text {lysMcre }}$ mice ............................50

4.3.1 EAE clinical disease curve …........................................... 50

4.3.2 Relative expression levels of AAM markers in PMs from EAE

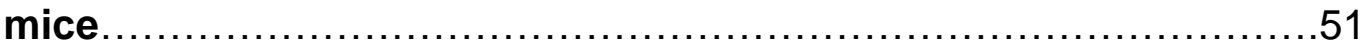

4.3.3 Relative expression levels of AAM markers in spinal cord infiltrating cells from EAE mice ................................................. 52

4.3.4 Histological analysis of EAE mice ................................54

4.4 Generation of inducible and reversible knockdown mouse

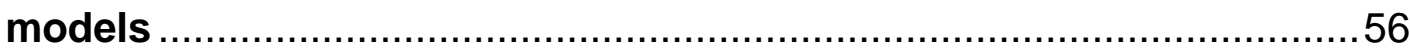

4.4.1 Simplifying the cloning procedure ...............................56

4.4.2 Cloning of shMR, shGR and shSirt1 sequences ................59

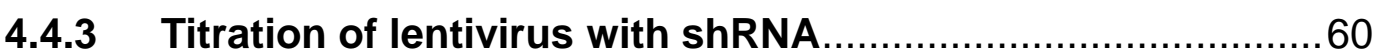

4.4.4 shRNA functional test in vitro .......................................6 61

4.4.5 Functional test of the shGR knockdown ........................67

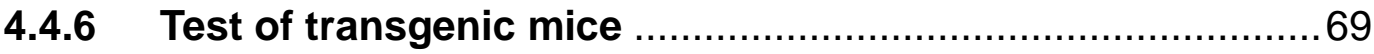




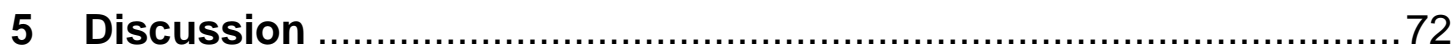

5.1 Effect of myeloid cell-specific ablation of MR on macrophages polarization ......................................................................... 72

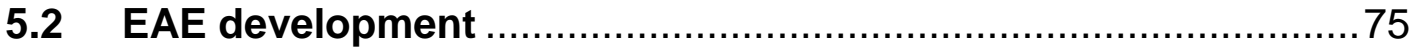

5.3 Generation of new transgenic mice ....................................... 79

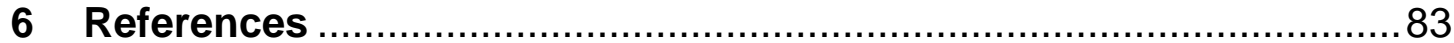




\section{Introduction}

\subsection{Mineralocorticoid receptor (MR)}

\subsubsection{Steroid hormone-receptor superfamily}

Steroid hormone receptors (SHRs) compose a subgroup of nuclear receptor (NC) superfamily. SHRs are involved in diverse physiological processes in animals, such as homeostasis, reproduction, development and metabolism, through binding with their ligands including: cortisol, aldosterone, progesterone, and Estrogen.

The SHRs are characterized by a unique modular structure model: It contains a variable $\mathrm{N}$-terminal region, a DNA binding domain (DBD), which is comprised of two zinc-finger motifs and responsible for DNA-protein or protein-protein interaction, the ligand-binding domain (LBD) located at the C-terminal region, which, is moderately conserved and folds into a canonical $\alpha$-helical sandwich generally consisting of $12 \alpha$-helices ( $\mathrm{H} 1$ to H12) (Lewis et al., 2005).

$\mathrm{MR}$ is the unique receptor among these receptors having two classes of hormone of ligands, the mineralocorticoids (MCs), aldosterone, and the glucocorticoids (GCs), cortisol (in human) and corticosterone (in rodent) (Mangelsdorf et al., 1995). This physiological character is the consequence of the highly homologous sequence between MR and glucocorticoid receptor (GR). The human GR and MR are $~ 56 \%$ identical in the steroid-binding domain (Pippal and Fuller 2008). Furthermore, ligand-binding studies of MR indicated that cortisol and aldosterone have a similar high affinity to the MR (Pippal and Fuller 2008; Viengchareun et al., 2007). 


\subsubsection{Transcriptional Mechanisms}

Initiation of SHR activity requires the binding of a specific ligand, such as GCs in the case of the GR. The SHRs then dimerize and translocate to the nucleus, and bind to their appropriate hormone response element (HRE) in the promoter of their target genes. Consequently, the SHRs recruit transcriptional co-regulatory proteins and ultimately RNA polymerase II and other components of the transcriptional machinery, commencing the transcription process (Horisberger et al., 1991).

\subsubsection{Molecular features of MR}

The mouse MR gene has been mapped to chromosome 8 and spans over $341 \mathrm{~kb}$ and is composed of 9 exons encoding the fulllength 980 amino acid MR protein. Similar to the other members of the nuclear receptor superfamily MR includes four structurally distinct domains: the $\mathrm{N}$-terminal domain (NTD), which contains activation function-1 (AF-1) and mediates ligand-independent interactions of the receptor with other nuclear proteins that initiate target gene transcription, followed by a central DNA-binding domain (DBD), which contains two zinc fingers that interact with specific hormone response elements (HRE) in the promoter regions of MR target genes, the hinge region and the C-terminal ligand-binding domain (LBD), which responses to binding ligand and contains a ligand-dependent activation function-2 (AF-2) (Pascual-Le et al., 2005; Govindan and Warriar, 1998).

The NTD has a highly conserved amino acid sequence, $\sim 85 \%$ homologous, in all MRs of mammals (Luisi et al., 1991). The AF-1 in the NTD is important for interactions with the transcriptional coregulators and for intramolecular interactions with the LBD (Bledsoe et al., 2005). The DBD contains two "zinc fingers" that is important for DNA recognition and 
binding. The DBD shares a highly conserved amino acid sequence with the other members of the steroid receptor superfamily, particularly with that of GR, $\sim 94 \%$ identity. Hence GR and MR share the same hormone response elements, GRE and MRE (Mangelsdorf et al., 1995). Additionally, the DBD is also response for homo- and heterodimerization ( $\mathrm{Li}$ et al., 2005). The LBD transforms upon binding ligand and represents the AF-2 that interacts with coactivators containing an LxxLL motif (Stewart and Mason et al., 1995; Perissi et al., 2005).Though the MR LBD has 55\% homology with that of GR, they share considerable structural and functional homology. Nonetheless, only the GCs bind to the MR with a similar affinity with aldosterone, but the aldosterone binds to the GR requiring a high, non-physiological concentration. In tissues the ligand specifity is ensured by expressing enzyme $11 \beta$-hydroxysteroid dehydrogenase type 2 (11ßHSD2), which metabolizes cortisol or corticosterone into inactive metabolites, cortisone, that are unable to bind MR (Canessa et al., 1994).

\subsubsection{Physiological functions of MR and its role in the immune system}

The first known function of $M R$ is regulating fluid and electrolytes homeostasis in epithelial tissues, such as kidney, colon etc., through direct stimulation the expression of specific ionic transporters, such as the amiloride-sensitive epithelial $\mathrm{Na}$ channel $(\mathrm{ENaC})$, and the basolateral $\mathrm{Na}+$, K+-ATPase pump (Viengchareun et al., 2007; Hsueh et al., 1998). These transporters are located in the apical membrane and responsible for unidirectional transepithelial sodium transport from the lumen to the basolateral space (Pu et al., 2003).

Moreover, new experimental and clinical data indicate that aldosterone can cause inflammatory damage through the MR to the heart, kidneys, and 
vasculature (Brown, 2008; Moraes et al., 2005). The in vivo and in vitro studies showed that the MR activation induces oxidative stress, vascular inflammation, and an increase in the expression of inflammatory biomarkers, such as fibrinogen and plasminogen activator inhibitor-1, which may contributes to progressive renal dysfunction and congestive heart failure (Lijnen et al., 1999; Schmidt et al., 2006; Leibovitz et al., 2009; Nishimura et al., 2008). In these aldosterone-induced inflammation diseases the macrophages attracted attention as a critical role. Leibovitz et al. has first reported the monocyte/macrophage is involved in aldosterone-induced oxidative stress and endothelial dysfunction (Fraccarollo et al., 2008). Many studies showed that administration of MR antagonists, spironolactone or eplerenone, reduces macrophage accumulation in many inflammatory diseases, such as peritoneal fibrosis (Rocha et al., 2002), myocardial infarction (Young et al., 2003) and angiotensin II-and aldosterone-induced vascular inflammation and damage (Calò et al., 2004; Herrada et al., 2010), whereas in macrophages, aldosterone treatment enhances expression of the inflammatory and oxidative stress markers (Ward et al., 1951). Gathering these date suggest a role of specific macrophages MR signaling in mediation the pro-inflammatory and oxidative phenotype in many pathologies. Additionally, MR can also alter the functions of dendritic cells (DCs), another cell type acts as antigen-presenting cells (APCs) by activating $T$ cells to evoke the adaptive immunity (Hench et al., 1949).

\subsubsection{Physiological functions of GR and its role in the immune system}

GR is a steroid receptor, belongs to the NR family of ligand-dependent transcription factor. GR's specific ligand (Caelles et al., 1997), GC is a term for all cholesterol-derived steroid molecules, which are important for metabolism, circadian rhythm, reproduction, and immunity. Edward 
Kendall, Tadeus Reichstein, and Philip Hench were awarded the Nobel Prize in 1950 for their work on isolating, synthesizing, and delivering cortisol (Miesfeld et al., 1984; Auphan et al., 1995), which leads to the discovery of cortisone as a therapeutic agent for rheumatoid arthritis. Since then GC and its synthetic derivates are in widespread use to treat inflammatory diseases, such as asthma, multiple sclerosis and allergy, etc. GR simultaneously affects the activation and effecter functions of immune cells, from both innate and adaptive immune systems, through manipulation of their transcriptional pathways. GR exerts anti-inflammatory effects through two mechanisms: DNA-binding-independent transrepression and DNA-binding- dependent transactivation. Transrepression does not require either GR dimerazation or binding to DNA (Reichardt et al., 2001), but by direct interaction of GR monomer with inflammatory transcription pathways, including AP-1 (Lim et al., 2007), NF-KB (Wang et al., 2006) signaling. Transactivation can induce transcription of anti-inflammatory genes, including IL10, GILZ, MKP-1 and IKBa (Reichardt et al., 1998, Tuckermann et al., 1999), which blockade the inflammatory transcription pathways by targeting signaling molecules in those pathways. Sight on the cellular response, GR can reduce macrophage-induced inflammatory responses (Ramírez et al., 1996), such as NO- and TNFa-production, and induce T cell apoptosis (Avital et al., 2006) or alter the T cell polarization (Datson et al., 2001).

However, as introduced above, GC can act either through GR or MR, which may lead to different physiological consequences. So far, all the studies, which indicated the anti-inflammatory effect of GC, are based on the GR signaling. The ligand binding-affinity studies on macrophages raise the question: how would GC affect on macrophages through MR signaling pathway. 


\subsubsection{Regulation of steroid hormone-receptors by Sirt1}

As introduced above, steroid hormone receptors play essential roles in numerous biological processes, such as homeostasis, metabolism, cell growth, and immune responses. Dysregulation of SHR signaling can lead to several types of tumors, such as breast cancer, leukemia and lymphoma, ovarian cancer, and lung cancer (Yang, 2006).

Sirt1 is a NAD/NADH-dependent histone deacetylase (HDAC) that functions by deacetylating histone $(\mathrm{H} 1, \mathrm{H} 3$, and $\mathrm{H} 4)$ and nonhistone proteins and involved in longevity, gene silencing, cell-cycle progression and energy homeostasis (Yamamoto, 2006; Dali-Youcef, 2007; Greiss and Gartner, 2009; Popov et al., 2007; Dai et al., 2007). Sirt1 has been reported involved in regulation of gene expression controlled by SHRs, such as androgen receptor (AR) (Yao et al., 2010; Lin et al., 2010), estrogen recetor (ER) (Yuan et al., 2009; Aoyagi and Archer, 2008), progesterone receptor (PR) (Amat et al., 2007; Zhang et al., 2009), GR and MR (Brand and Esteves, 2005; Fan et al., 2011). Here we particularly focus on the interactions between Sirt1, GR and MR.

The recent studies of the interaction between GR and Sirt1 are restricted in mitochondria related regulation of metabolism in skeletal muscle cells. After binding with ligand GR activates the transcription of uncoupling protein-3 (UCP3), a mitochondrial membrane transporter that protects muscle cells from an overload of fatty acids and protects against excessive production of reactive oxygen species (Schenk et al., 2011). This process requires interaction between GR and the co-activator p300 at the promoter, which is possibly completely inhibited by Sirt1 or its activator resveratrol (Brand and Esteves, 2005). Despite it has been long reported p300 as well as GR play important role in inflammatory or auto-immune diseases, so far the involvement of Sirt1 through GR signaling in these diseases remains unclear. 
In the case of MR, so far the interaction between Sirt1 and MR remains also widely unclear. Only a few papers (Fan et al., 2011, Rutschman et al., 2001) showed: on the one hand Sirt1 can suppress the MR mediated gene transcription, such as $\mathrm{aENaC}$, without its deacetylase activity; on the other hand Sirt1 expression is also under the control of aldosterone.

Although there is no evidence linking the interaction of GR/MR and Sirt1 with immune diseases, it is been known that Sirt1 regulates PI3K, an important component of many of the steroid hormone signaing pathways, depending on cellular metabolism level (Schebesch et al., 1997), which provides us a clue to find the involvement of Sirt1 in immune system through GR or MR.

\subsection{Macrophages}

Macrophages play important role in innate as well adaptive immunity, by phagocyting pathogens and as antigen presenting cell (APC) stimulating lymphocytes to respond to pathogens, respectively.

The macrophages are generated from committed hematopoietic stem cells located in the bone marrow. Macrophage precursors leave bone marrow as monocytes and circulate throughout the body until they are recruited in tissues, including the spleen, which serves as a storage reservoir for immature monocytes (Gordon, 2003). After drilling into tissues the monocytes become specialized tissue-resident macrophages including osteoclasts (bone), alveolar macrophages (lung), Kupffer cells (liver) and microglia cells (central nervous system (CNS)).

Depending on the specific milieu, such as altered host cells, modified molecules and exogenous agents, the macrophages can be activated generally into two types, classically activated macrophages (CAM) and alternatively activated macrophages (AAM), which are described with 
distinct functions not only in immunity but also in many other physiological processes.

\subsubsection{Classically activated macrophages (CAM)}

The "classical" activation of macrophages was first studied in the 1960s by Mackaness and colleagues (Goverman, 2011) by showing that infection of mice with Mycobacterium bovis bacillus Calmette-Guerin (BCG) or Listeria monocytogenes enhanced the antimicrobial activities of macrophages in a stimulus dependent, but unspecific, manner (Dull, 1998). The polarization of macrophages toward the CAM phenotype is promoted by bacterial moieties such as lipopolysaccharide (LPS) and the $T_{H} 1$ cytokine interferon- $\mathrm{Y}$ (IFN-Y) (Dull, 1998). These CAM exhibit a $\mathrm{T}_{\mathrm{H}} 1$ related inflammatory response, such as producing large amounts of proinflammatory cytokines and generate reactive oxygen (ROI) and nitric oxide through the inducible nitric oxide synthase (iNOS or NOS2). The response of CAM contributes to cellular immunity, immunodeficiency syndromes and tissue damage.

\subsubsection{Alternatively activated macrophages (AAM)}

AAM, also termed as M2 macrophages, were typically defined by alternative activation by IL-4 and IL-13, typical $T_{\mathrm{H}} 2$ cytokines. Thereafter, it is been found the macrophages, which are activated by transforming growth factor (TGF) family of cytokines, glucocorticoids, macrophage colony-stimulating factor (M-CSF), overlaps patterns of gene expression with the AAMs, which are activated by IL-4 and IL-13 (Arriza et al., 1987). AAMs have potential to mediate wound-healing, angiogenesis, anti-inflammatory response.

The AAMs express some hallmarked genes in contrast to CAMs, for 
example, CD163, mannose receptor (CD206), scavenger receptor2 (Msr2), F13a1, Fizz1, Ym1, Arginase1 and MHC II molecules (Gordon, 2003). Due to induction of Arginase, AAMs do not produce NO in contrast to CAMs (Mosser, 2003).

\subsubsection{Effects of sterocorticoids on the differentiation of macrophages}

Corticosteroids include two classes of steroid hormones, GC and MC. It has long been known that in absence of 11ßHSD2 MR coordinate the cellular responses against that of GR in brain (Richard and Young, 2009; Richard et al., 2009). These two corticosteroid receptors spread their counteractions on macrophage responses (Tanaka et al., 1997; Usher et al., 2010; Hench et al., 1950), and further on macrophage polarization (Gratchey et al., 2005).

The GC induced AAM shares with that induced by IL-4 some common characteristics, such as repression the inflammatory cytokines by inhibition of NFKB and AP-1, increase in expression of the macrophage mannose receptor and elevation of endocytosis. Nonetheless, due to different signaling pathways, GR counteracts against IL-4, particularly on expression of extracellular matrix (ECM) proteins (Iglarz et al., 2003). In absence of $11 \beta H S D 2$, macrophage MR is overwhelmingly occupied by GC. Furthermore, MR and GR have largely opposing roles in macrophages, and the effects of MR are independent of GR (Lyons et al., 2007). The putative effect of MR on macrophages polarization was elicited by the studies on Peroxisome Proliferator-Activated Receptor gamma (PPARY), a nuclear hormone receptor. The activated PPARY can also polarize macrophages towards alternatively activated state and partially overlaps that activated by GR (Caglayan et al., 2008). On the other hand, the effect of MR antagonists in mitigating cardiac and vascular 
inflammation and fibrosis was found to be similar to that of activation of PPARy by pioglitazone (Usher et al., 2010; Blasi et al., 2003). As Usher and his colleagues, 2010 showed: MR inhibition eliminates a suppression of AAM polarization, resulting in a macrophage phenotype that is similar to that induced by GCs (acting through GR).

Gathering the information together, the GR and MR play opposing roles in macrophages and skew macrophage polarization toward AAM and CAM, respectively.

\subsubsection{Role of Macrophages in neuroinflammatory diseases}

Neuroinflammation represents a coordinated cellular response to tissue damage, including diseases such as MS, Alzheimer's disease (AD) and Parkinson's disease (PD). Hence, the inflammatory responses on tissue injury induced by the CNS resident macrophages, microglias, and infiltrating macrophages in case of MS attract many focuses.

Microglias in the CNS serve as the resident immune cells and provide the first line of defense against invading microbes. In healthy individual, the neurons express CD200 (Kraft and Harry, 2011) to maintain the microglias in a quiescent state through the CD200 receptor (CD200R) on microglias surface (Colton, 1995). Under stress or damages the neurons release specific factors, such as matrix metalloproteinase-3 (MMP-3), neuromelanin, heat shock proteins (HSP60, HSP70, HSP90), DNA, proteases, uric acid and the chromosomal protein high-mobility group B1 (HMGB1) (Thiel and Audus, 2001). These stimulate inflammatory response through NFKB and AP-1 signaling pathways, which modulate pro-inflammatory target genes encoding cytokines, chemokines, enzymes, and other molecules essential for pathogen elimination. Additionally, microglia express iNOS, which uses L-arginine to produce NO, which is considered as cytotoxic, particularly at high levels, as shown with 
oligodendrocytes in culture and studies of direct effects on BBB permeability (Bal-Price et al., 2001; Brodie et al., 1998), which may contributes to infiltration of the leukocytes from blood into CNS. NO can also inhibit neuronal respiration, causing depolarization, glutamate release from neurons and astrocytes (Kitamura et al. 2000; Odegaard et al., 2007). Since the inflammatory responses induced by macrophages play a pivotal role in neuron degeneration, induction of the AAM in the microglia and infiltrating macrophage population becomes a potential approach to reduce neuroinflammatory diseases severity. First, the polarization skewing from CAM to AAM switches the macrophages from a proinflammatory to an anti-inflammatory state, in which the expression levels of proinflammatory cytokines are reduced, such as IL1 $\beta$, IL6 and TNF $\alpha$ etc, and the expression of IL10, TGF- $\beta$, insulin growth factor 1 (IGF-1) and PPARy are elevated, which are generally associated with the repair and reconstruction after injury (van Rossum et al., 2008; Siffrin et al., 2007; Beeton et al., 2007; Schreiner et al., 2009). Second, the AAMs express more Arginase1 and less iNOS, which results in reduced NO levels in CNS. Third, the AAMs exert a higher phagocytotic activity of apoptotic cells compared to CAMs, which may facilitate the clearance of the lesion sites in CNS and neuron regeneration.

\subsection{Multiple sclerosis (MS) and Experimental autoimmune encephalomyelitis (EAE)}

MS, a chronic neuroinflammatory demyelinating disease was initially identified in 1868 by Charcot. This disease often begins in young adulthood with intermittent episodes of neurological dysfunction, including visual impairment, ataxia, motor and sensory deficits, and bowel and bladder incontinence. These are attributable to recurrent inflammatory 
attacks on the white matter of the brain and spinal cord, which lead to the accumulation of perivascularly distributed inflammatory cells within the brain and spinal cord white matter (Rivers et al., 1933).

Beeton et al. first established an animal model of MS in the 1930s, when they immunized monkeys with a central nervous system (CNS) homogenate to induce what is now known as experimental autoimmune encephalomyelitis (EAE) (Steinman et al., 2006). Since then EAE has become the most accepted animal model of MS. In recent decades, pathogenic hypotheses have been investigated and novel therapeutic agents tested in this model in the fields of CNS inflammation and demyelination. Therefore, EAE provides a valuable tool for the investigation of the T-cell-dependent pathogenesis of autoimmune inflammation in the CNS and the orchestration of the autoimmune demyelinating inflammation in the CNS of MS patients. Mice and/or genetically modified mice have also been of fundamental value in the exploration of the complex pathogenesis of MS (Chiu et al., 2009; Nielsen et al., 2006). EAE is undoubtedly the best animal model in which to study autoimmune diseases and particularly the demyelinating diseases of the CNS, such as MS (Berger et al., 2005).

\subsection{RNA interference}

A key aspect of the regulation of eukaryotic gene expression is the cytoplasmic control of mRNA translation and degeneration. Over the last decade, miRNAs and siRNAs have raised as novel important regulators of translation and mRNA degradation. The relative regulations mediated by these small RNAs are referred to as RNA interference (RNAi) or RNA silencing. There are two general pathways to silence cytoplasmic mRNAs either by triggering an endonuclease cleavage, resulting in translation 
repression, or by enhancing mRNA degradation (Carmell and Hannon, 2004). Previously, it has been thought that the difference between these two silencers was the different outcomes of silencing, miRNA repressed the translation and siRNA enhanced degradation of mRNA. However, the recent findings showed both miRNA and siRNA are functionally equivalent, and their outcome of silencing depends on the extent of base pairing (Zeng et al., 2003; Denli et al., 2004), enhancing mRNA degradation by complete complementary in sequence or repressing translation by partial complementarity. Nonetheless, they can still be distinguished by their mode of biogenesis (Hutvagner and Zamore, 2002; Doench et al., 2003): miRNAs are produced endogenously from transcripts that form stem-loop structures, while siRNA are produced artificial or also endogenously processed from long double-stranded RNA (dsRNA) and complex hairpin precursors (shRNA) by sharing the same producing machinery with miRNA.

Since I used lentivirus to transfect target cells with plasmid encoding the sequence, which formed shRNA structure after transcription, I will only use the term siRNA in following text.

\subsubsection{The Mechanisms of RNA interference}

The first precursor of shRNA, is a transcript in the nucleus made by polymerase II or polymerase III and forms a stem-loop structure. This transcription product is processed in the nucleus by a complex comprised of at least two components: the RNase III enzyme Drosha, and a protein DGCR8 (homologue protein in yeast called Pasha) (Gregory et al., 2004; Han et al., 2004; Landthaler et al., 2004; Lee et al., 2003; Yi et al., 2003; Lund et al., 2004). The intermediate, termed pre-shRNA due to its "hair spin" similar structure is then exported from nucleus in cytoplasm by Exportin 5. Subsequently the pre-shRNA is cleaved into double strand 
RNA (dsRNA) by the cytoplasmic RNase III endonuclease Dicer complex (Gregory et al., 2005; Glaser et al., 2005). Final processing by Dicer coupled to assembly of the dsRNA intermediate into RNA-induced silencing complex (RISC) (Benson et al., 2006), where the sense (passenger) strand is degraded. The left antisense (guide) strand leads RISC to mRNA that has a complementary sequence. As above mentioned, the degree of complementarity determines the mRNA degradation or disruption of translation.

\subsubsection{The Inducible and reversible gene knockdown system}

The development of knockout mice by homologous recombination in embryonic stem cells (Seibler et al., 2007) is a revolutionary method for research in many fields in medicine and biology. Nevertheless, this method cannot fulfill every requirement in research, due to its limitation: It is not suitable for all genes that are indispensable for individual development and not reversible. The novel shRNA technique provides an efficient approach for this goal by using engineered RNA polymerase III-dependent promoters containing operator sequence (tetO) of the tetracycline resistance operon (Szymczak and Vignali, 2005; Geissmann et al., 2010 and Figure 1).

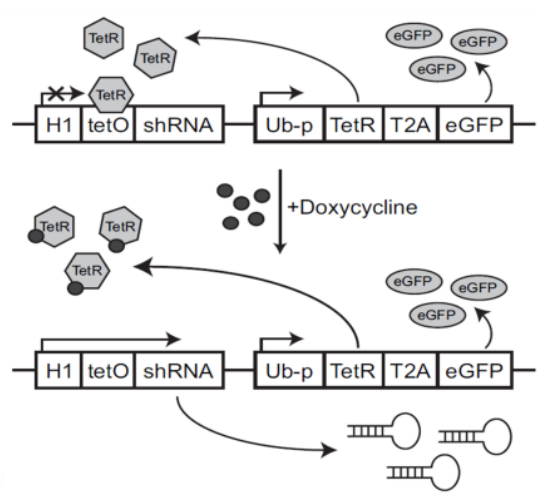

Figure 1: Operating principle of the lentiviral single-vector system. From Marco J. 
Herold et al., 2008. The vector contains two cassettes: the shRNA is placed in the first one and regulated by the $\mathrm{H} 1$ promoter with tetO; the tetR and EGFP are linked by viral T2A peptide and constitutively expressed unter ubiquitin C promoter (Ub-p). In the absence of Dox, the tetR binds to tetO and blocks shRNA transcription. After addition of Dox, the tetR is removed, which allows the shRNA transcription occurring.

This novel gene knockdown system is comprised of two cassettes. The first and second cassettes both have its own promoter, H1-promoter $(\mathrm{H} 1-\mathrm{p})$ and ubiquitin $C$ promoter $(U b-p)$, respectively. The shRNA sequence is placed in the first cassette downstream of the $\mathrm{H} 1-\mathrm{p}$, which is controlled by the tetO. In the second cassette, the Ub-p is responsible for the expression of the downstream tet represser (tetR) and eGFP. Independent expression of these two genes under one promoter was guaranteed by the viral T2A peptide (Machaness, 1964), which is placed between the tetR and eGFP. tetR is continuously expressed and binds immediately to tetO, which leads to inhibiton of shRNA transcription. Addition of doxycycline rescues $\mathrm{H} 1-\mathrm{p}$ activity by removing tetR from tetO, which allows the transcription of shRNA occurring.

With this engineered system, shRNA transcription can be controlled by this operon, so that we can temporally and reversibly knockdown the target gene expression by "turning on" or "turning off" the operon. Hence this technique can help us avoid such problems by generating transgenic mice, in which the target protein is essential for individual development and growth.

\subsubsection{Lentiviruses and their use as vector systems}

Derived from HIV, Lentivirus, a genus of the retroviridae family, becomes a powerful vehicle for gene delivery in vivo, because of their unique ability to infect nondividing cells and stable long term expression of the transgene 
(Yee et al., 1994). Since the first application of lentivirus in research, their biosafety is of major concern.

The complexity of the lentivirus genome provides a chance to archive biosafety in practical application. In addition to the structural gag, pol, and env genes shared with all retroviruses, HIV contains two regulatory genes, tat and rev, essential for viral replication, and four accessory genes, vif, vpr, $v p u$, and nef, which are not crucial for viral growth but are critical for in vivo pathogenesis (Moore et al., 2012). In order to archive biosafety in application, we used a four-plasmid vector system, termed the third generation lentiviral vector system. In this system the target gene is placed in one plasmid and the other essential genes are separated in three plasmids: gag and pol, coding for the virion main structural proteins and the retrovirus-specific enzymes, respectively, are driven by CMV promoter and placed in pMDLg/pRRE; The Rev response element (RRE) is immediately placed downstream of gag and pol sequence; RRE binding with Rev, whose cDNA is encoded by rev separately placed in pRSV-Rev, facilitates exporting mRNA of gag and pol genes from nucleus; the env is replaced by $v s v-g$, coding the $G$ glycoprotein of the vesicular stomatitis virus, is also alone placed on a third helper plasmid and under the control of the CMV promoter (Haigis et al., 2006); the VSV-G enhances the tropism of virus and facilitates infection. Due to demand of biosafety, after delivery of gene into target cells by lentiviruses we do not need any replication competent lentivirus $(\mathrm{RCL})$ to be generated in target cells. In the three helper plasmids, the packaging sequence (Psi) is deleted, which prevents the transcript mRNAs of these structural proteins assembled into the new generated viral particle. Only one the plasmid with the gene of interest is transcript with Psi and gets incorporated into the new viruses. Hence, the new generated viruses can only infect the target cells but are not able to reproduce themselves. There is only one possibility that they still can reproduce in the target cells: as consequence of series 
recombination the Psi is also placed in the all three helper plasmids. Therefore, by splitting the vector system into four plasmids ( 3 helper and 1 vector), the number of recombination events required to form a complete $\mathrm{RCL}$ increases enormously. To date there are no known cases where this type of construct has produced RCL (Yee et al., 1994).

\subsection{Objective}

The aim of this project was to determine the role of MR in macrophage polarization. If our hypothesis that MR knockout can skew macrophage polarization more towards AAM, the individual could benefit from the AAM polarization in inflammatory diseases, such as the EAE model. It can also expend our knowledge about the metabolism and immune system, as well as provide new approach to reduce disease severity.

Furthermore if during this project, the generation of new transgenic mice is archived, the further study of the linkage between MR and immune system can be started. 


\section{Material}

\subsection{General equipments}

\begin{tabular}{|c|c|}
\hline Accu-jet $\circledast$ pro pipette controlle & Brand $\mathrm{GmbH}$, Wertheim \\
\hline $\begin{array}{l}\text { Arium } \AA \quad 611 \text { laboratory } \text { water } \\
\text { purification system }\end{array}$ & Sartorius AG, Göttingen \\
\hline Centrifuge 5471R for reaction tubes & Eppendorf, Hamburg \\
\hline Centrifuge 5904 for FACS tubes & Eppendorf, Hamburg \\
\hline $\begin{array}{l}\text { Centrifuge multifuge } 4 \mathrm{KR} \text { for falcon } \\
\text { tubes }\end{array}$ & Heraeus, Hanau \\
\hline $\begin{array}{l}\text { Centrifuge Sigma } 2-5 \text { for } 96 \text {-well } \\
\text { plates }\end{array}$ & $\begin{array}{l}\text { SIGMA Laborzentrifugen } \mathrm{GmbH} \text {, } \\
\text { Osterode am Harz }\end{array}$ \\
\hline Electrophoresis power supply 301 & Amersham Biosciences, Freiburg \\
\hline Freezer Hera freeze $-80^{\circ} \mathrm{C}$ & Heraeus, Hanau \\
\hline Freezer Liebherr Comfort $-20^{\circ} \mathrm{C}$ & $\begin{array}{l}\text { Liebherr-International Deutschland } \\
\text { GmbH, Biberach an der Riss }\end{array}$ \\
\hline Freezer VIP plus $-150^{\circ} \mathrm{C}$ & $\begin{array}{lll}\text { SANYO Electric Co., } & \text { Ltd., } \\
\text { Moriguchi, Osaka, Japan }\end{array}$ \\
\hline Incubator, HERAcell 240 & Heraeus, Hanau \\
\hline Laminar airflow cabinet, HERASafe & Heraeus, Hanau \\
\hline $\begin{array}{l}\text { Micropipettes } 2.5 \mu \mathrm{l}, 20 \mu \mathrm{l}, 200 \mu \mathrm{l} \text {, } \\
1000 \mu \mathrm{l}\end{array}$ & Eppendorf, Hamburg \\
\hline Microscope Primo Star & Zeiss, Jena \\
\hline Microscope Telaval 31 & Zeiss, Jena \\
\hline $\begin{array}{l}\text { Neubauer improved } \\
\text { haemocytometer precicolor }\end{array}$ & $\begin{array}{l}\text { Henneberg-Sander } \\
\text { Giessen-Lützellinden }\end{array}$ \\
\hline pH-Meter 766 Calimatic & $\begin{array}{l}\text { Knick Elektronische Messgeräte } \\
\text { GmbH \& Co. KG, Berlin }\end{array}$ \\
\hline RS 225 X-Ray Research System & $\begin{array}{lcc}\text { Gulmay } & \text { Medical } & \text { Systems, } \\
\text { Camberley, Surrey, UK } & \\
\end{array}$ \\
\hline Scales TE313S & Sartorius AG, Göttingen \\
\hline Shaker 3006 & $\begin{array}{l}\text { Gesellschaft für Labortechnik, } \\
\text { Burgwedel }\end{array}$ \\
\hline $\begin{array}{l}\text { UV System with camera and gel } \\
\text { imager }\end{array}$ & $\begin{array}{l}\text { INTAS Science Imaging Instruments } \\
\text { GmbH, Göttingen }\end{array}$ \\
\hline Vortex Genie-2 & $\begin{array}{ll}\text { Scientific } & \text { Industries, } \\
\text { Bohemia, New York, USA }\end{array}$ \\
\hline Water bath & Labortechnik Medingen, Dresden \\
\hline
\end{tabular}




\subsection{Consumables}

\begin{tabular}{|c|c|}
\hline $\begin{array}{l}\text { 96-well Suspension Culture Plate, } \\
\text { flat bottom }\end{array}$ & $\begin{array}{l}\text { Greiner bio-one } \mathrm{GmbH} \text {, } \\
\text { Frickenhausen }\end{array}$ \\
\hline $\begin{array}{l}\text { Cell culture plates } 3.5 \mathrm{~cm}, 6 \mathrm{~cm}, 10 \\
\mathrm{~cm}\end{array}$ & Sarstedt, Nümbrecht \\
\hline Cell strainer $40 \mu \mathrm{m}$ & BD biosciences, Heidelberg \\
\hline Cellstar ${ }^{\circledR}$ pipettes $5 \mathrm{ml}, 10 \mathrm{ml}, 25 \mathrm{ml}$ & $\begin{array}{l}\text { Greiner bio-one } \mathrm{GmbH} \text {, } \\
\text { Frickenhausen }\end{array}$ \\
\hline CryoTube $^{\mathrm{TM}}$ Vials & Nunc, Roskilde, Denmark \\
\hline ELISA plates & Nunc, Roskilde, Denmark \\
\hline FACS tubes & BD biosciences, Heidelberg \\
\hline Filtropur S 0.45 & Sarstedt, Nümbrecht \\
\hline Needles & $\begin{array}{l}\text { B. Braun Melsungen AG, } \\
\text { Melsungen }\end{array}$ \\
\hline Pipette tips $10 \mu \mathrm{l}$ & Sarstedt, Nümbrecht \\
\hline Pipette tips $200 \mu \mathrm{l}, 1000 \mu \mathrm{l}$ & $\begin{array}{l}\text { Greiner bio-one } \mathrm{GmbH} \text {, } \\
\text { Frickenhausen }\end{array}$ \\
\hline Reaction tube $1.5 \mathrm{ml}, 2 \mathrm{ml}$ & $\begin{array}{l}\text { Greiner bio-one } \mathrm{GmbH} \text {, } \\
\text { Frickenhausen }\end{array}$ \\
\hline Syringers $1 \mathrm{ml}$ & Henke Sass Wolf, Tuttlingen \\
\hline Syringers $2 \mathrm{ml}, 5 \mathrm{ml}, 10 \mathrm{ml}$ & BD biosciences, Heidelberg \\
\hline
\end{tabular}

\subsection{Chemicals and buffers}

$$
\begin{array}{l|l}
\hline 3,3^{\prime}, 5,5^{\prime} \text {-Tetramenthylbenzidine } & \text { SIGMA-Aldrich, Taufkirchen }
\end{array}
$$




\begin{tabular}{|c|c|}
\hline Agarose UltraPure & Invitrogen, Paisley, UK \\
\hline Bovine serum albumin (BSA) & Carl Roth, Karlsruhe \\
\hline $\mathrm{CaCl}_{2} \cdot 2 \mathrm{H}_{2} \mathrm{O}$ & Merck, Darmstadt \\
\hline Citric acid & Merck, Darmstadt \\
\hline Dex water soluble & SIGMA-Aldrich, Taufkirchen \\
\hline Dimethyl sulfoxide (DMSO) & Carl Roth, Karlsruhe \\
\hline DNA ladder $1 \mathrm{~kb}$ & Fermentas GmbH, St. Leon-Rot \\
\hline $\begin{array}{l}\text { Ethylenediaminetetraacetic acid } \\
\text { (EDTA) }\end{array}$ & Serva, Heridelberg \\
\hline Ethanol & Carl Roth, Karlsruhe \\
\hline Ethidium bromide & Carl Roth, Karlsruhe \\
\hline Fetal calf serum (FCS) & HyClon, Peribio Science, Bonn \\
\hline GIBCO® Penicillin/Streptomycin & Invitrogen, Paisley, UK \\
\hline $\mathrm{H}_{2} \mathrm{O}_{2} 30 \%$ & Carl Roth, Karlsruhe \\
\hline $\mathrm{H}_{2} \mathrm{SO}_{4}$ & Merck, Darmstadt \\
\hline $\mathrm{HCl}$ & Carl Roth, Karlsruhe \\
\hline $\begin{array}{l}\text { 4-(2-hydroxyethyl)-1-piperazineetha } \\
\text { ne-sulfonic acid (HEPES) }\end{array}$ & Merck, Darmstadt \\
\hline $\mathrm{KCl}$ & Merck, Darmstadt \\
\hline $\mathrm{KH}_{2} \mathrm{PO}_{4}$ & Merck, Darmstadt \\
\hline $\mathrm{KHCO}_{3}$ & Merck, Darmstadt \\
\hline $\mathrm{Na}_{2} \mathrm{CO}_{3}$ & Merck, Darmstadt \\
\hline $\mathrm{Na}_{2} \mathrm{HPO}_{4} \cdot 12 \mathrm{H}_{2} \mathrm{O}$ & Merck, Darmstadt \\
\hline $\mathrm{Na}_{3} \mathrm{C}_{6} \mathrm{H}_{5} \mathrm{O}_{7}$ & Carl Roth, Karlsruhe \\
\hline $\mathrm{NaCl}$ & Carl Roth, Karlsruhe \\
\hline $\mathrm{NaH}_{2} \mathrm{PO}_{4} \cdot \mathrm{H}_{2} \mathrm{O}$ & Merck, Darmstadt \\
\hline $\mathrm{NaHCO}_{3} \cdot 3 \mathrm{H}_{2} \mathrm{O}$ & Merck, Darmstadt \\
\hline $\mathrm{NaN}_{3}$ & Carl Roth, Karlsruhe \\
\hline $\mathrm{NaOH}$ & SIGMA-Aldrich, Taufkirchen \\
\hline
\end{tabular}




\begin{tabular}{|l|l|}
\hline Doxycycline & SIGMA-Aldrich, Taufkirchen \\
\hline $\mathrm{NH}_{4} \mathrm{Cl}$ & Merck, Darmstadt \\
\hline Percoll & SIGMA-Aldrich, Taufkirchen \\
\hline $\begin{array}{l}\text { Tris(hydroxymethyl)aminomethane } \\
\text { (Tris) }\end{array}$ & Carl Roth, Karlsruhe \\
\hline Tween-20 & Carl Roth, Karlsruhe \\
\hline
\end{tabular}

\subsection{Media and solutions}

GIBCO $\circledast$ DMEM+GlutaMAX ${ }^{\text {TM }}$-I, Invitrogen, Paisley, UK

GIBCO® RPMI 1640+GlutaMAX ${ }^{\text {TM}}$-I, Invitrogen, Paisley, UK

RPMI and DMEM complete:

$+10 \%$ FCS

$+1 \%$ Penicillin/Streptomycin

PBS: $\mathrm{pH} 7.4$

$137 \mathrm{mM} \mathrm{NaCl}$

$2.7 \mathrm{mM} \mathrm{KCl}$

$10 \mu \mathrm{M} \mathrm{Na}_{2} \mathrm{HPO}_{4}$

$2.0 \mathrm{mM} \mathrm{KH}_{2} \mathrm{PO}_{4}$

Cell dissociation buffer:

PBS pH 7.4

2mM EDTA

Transfection buffer (2X HBS):

50 mM HEPES,

$10 \mathrm{mM} \mathrm{KCl}$

$12 \mathrm{mM}$ dextrose

$280 \mathrm{mM} \mathrm{NaCl}$

$1.5 \mathrm{mM} \mathrm{Na2PO} 4$

After dissolving these components, the solutions $\mathrm{pH}$ value was set to 6.9 
at $22{ }^{\circ} \mathrm{C}$.

FACS buffer:

PBS pH 7.4

$0.1 \%$ BSA

$0.01 \% \mathrm{NaN}_{3}$

\subsection{List of Antibodies used in flow cytometry (FACS) and western blot}

\subsubsection{FACS antibodies}

\begin{tabular}{|c|c|c|c|c|}
\hline Antigen & Dye & Clone & $\begin{array}{c}\text { Final } \\
\text { dilution }\end{array}$ & Supplier \\
\hline CD11b & PE-Cy7 & M1/70 & $1: 2000$ & BD \\
Biosciences
\end{tabular}

BD Biosciences, Heidelberg

\subsubsection{Western blot antibodies}

\begin{tabular}{|l|l|l|l|}
\hline \multicolumn{1}{|c|}{ Antigen } & \multicolumn{1}{c|}{ Clone } & Final dilution & \multicolumn{1}{c|}{ Supplier } \\
\hline MR & H10E4C9F & $1: 1000$ & ABcam \\
\hline
\end{tabular}




\begin{tabular}{|l|l|l|l|}
\hline GR & polyclonal & $1: 500$ & Santa Cruz \\
\hline Sirt1 & polyclonal & $1: 1000$ & Sigma-Aldrich \\
\hline$\beta$-Tubulin & polyclonal & $1: 500$ & ABcam \\
\hline
\end{tabular}

\subsection{Molecular biology reagents}

\subsubsection{Enzymes used in cloning}

For cloning, I used the following restricted endonucleases: Agel, Xhol, Xbal, EcoRl, Bglll, BamHI, HindlII, Kpnl, Notl, Sall and T4 ligase for ligation, Phusion $\AA^{\circledR}$ polymerase for mutagenesis PCR, which are all supplied by New England Biolabs ${ }^{\circledR}$.

\subsubsection{Primers used for mutagenesis PCR}

\begin{tabular}{|c|c|}
\hline Primer & Sequence \\
\hline \multirow{3}{*}{ H1 tet-Agel } & forward: CGCCATGGATTCGAACGCT \\
\cline { 2 - 3 } & $\begin{array}{c}\text { reverse: } \\
\text { CGTCTCGAGTCTAGACCTAGACCGGTAGGGAATCTCTATCACTGA } \\
\text { TAGG }\end{array}$ \\
\hline H1 tet Sall & GGCGGCCGCTCTAGTTCTAGAAGCTTCGTCAGTTGG \\
\hline Xbal shift & forward: GGCGGCCGCTCTAGTTCTAGAAGCTTCGTCAGTTGG \\
\cline { 2 - 2 } $\begin{array}{c}\text { Primer for } \\
\text { shRNA } \\
\text { sequencing }\end{array}$ & TGCGCCCTTCGTCTGACGTG \\
\hline
\end{tabular}




\subsection{3 shRNA sequence}

The Following sequences were cloned into "FH1UTG-Agel new" lentiviral vector:

ShMR:

"Seq. 1":

Sence:

CCGGCCATGGGTTTATACATGGATTTTCAAGAGAAATCCATGTATAAA CCCATGGTTTTTC

Anti-sence:TCGAGAAAAACCATGGGTTTATACATGGATTTCTCTTGAAA ATCCATGTATAAACCCATGG

"Seq. 2":

Sence:

CCGGCCTTTCCCTAAGACAGAGGAATTCAAGAGATTCCTCTGTCTTA GGGAAAGGTTTTTC

Anti-sence:

TCGAGAAAAACCTTTCCCTAAGACAGAGGAATCTCTTGAATTCCTCT GTCTTAGGGAAAGG

"Seq. 3":

Sence:

CCGGCGGCAAATCTTAACAATTCAATTCAAGAGATTGAATTGTTAAGA TTTGCCGTTTTTC

Anti-sence:

TCGAGAAAAACGGCAAATCTTAACAATTCAATCTCTTGAATTGAATTG TTAAGATTTGCCG

"Seq. 4":

Sence:

CCGGGCTCTACTTTACGAAGTGTTTTTCAAGAGAAAACACTTCGTAA AGTAGAGCTTTTTC

Anti-sence:

TCGAGAAAAAGCTCTACTTTACGAAGTGTTTTCTCTTGAAAAACACTT CGTAAAGTAGAGC

"Seq. 5":

Sence:

CCGGCCAAGGTACTTCCAGGATTTATTCAAGAGATAAATCCTGGAAG TACCTTGGTTTTTC 
Anti-sence:

TCGAGAAAAACCAAGGTACTTCCAGGATTTATCTCTTGAATAAATCCT GGAAGTACCTTGG

\section{shGR:}

Sence:

CCGGGCTCCTGATCTGATTATTAATTTCAAGAGAATTAATAATCAGATC AGGAGCTTTTTC

Anti-sence:

TCGAGAAAAAGCTCCTGATCTGATTATTAATTCTCTTGAAATTAATAAT CAGATCAGGAGC

\section{shSirt1:}

"Seq. 1"

Sence:

CCGGGCCACCAACACCTCTTCATATTTTCAAGAGAAATATGAAGAGGT GTTGGTGGCTTTTTC

Anti-sence:

TCGAGAAAAAGCCACCAACACCTCTTCATATTTCTCTTGAAAATATGAA GAGGTGTTGGTGGC

"Seq. 2"

Sence:

CCGGAGAGGTTGTTAATGAAGCTATATTCAAGAGATATAGCTTCATTAA CAACCTCTTTTTTC

Anti-sence:

TCGAGAAAAAAGAGGTTGTTAATGAAGCTATATCTCTTGAATATAGCTT CATTAACAACCTCT

"Seq. 3"

Sence:

CCGGCCACAAGAAGTACAGACTAGTATTCAAGAGATACTAGTCTGTAC TTCTTGTGGTTTTTC

Anti-sence:

TCGAGAAAAACCACAAGAAGTACAGACTAGTATCTCTTGAATACTAGT CTGTACTTCTTGTGG

"Seq. 4"

Sence:

CCGGGTAGCACTAATTCCAAGTTCTATTCAAGAGATAGAACTTGGAAT TAGTGCTACTTTTTC

Anti-sence:

TCGAGAAAAAGTAGCACTAATTCCAAGTTCTATCTCTTGAATAGAACTT GGAATTAGTGCTAC 


\subsubsection{Enzyme linked immunosorbant Assay (ELISA)}

\begin{tabular}{|c|c|}
\hline Coating buffers & $0.1 \mathrm{M}$ sodium carbonate, $\mathrm{pH} 9.5$ \\
\hline Assay diluents & $10 \% \mathrm{v} / \mathrm{v}$ FCS in PBS, pH 7.4 \\
\hline Wash buffer & $0.05 \% \mathrm{v} / \mathrm{v}$ Tween-20 in PBS, $\mathrm{pH} 7.4$ \\
\hline Substrate buffer & $\begin{array}{l}0.1 \mathrm{M} \text { Citric Acid, } 0.2 \mathrm{M} \mathrm{Na}_{2} \mathrm{HPO} 4 \text { in } \\
\mathrm{ddH}_{2} \mathrm{O}\end{array}$ \\
\hline TMB solution & $\begin{array}{l}1 \% \text { w/v } 3,3^{\prime}, 5,5^{\prime}-\text { Tetramenthyl- } \\
\text { benzidine in DMSO }\end{array}$ \\
\hline Substrate solution & $\begin{array}{l}10 \% \mathrm{v} / \mathrm{v} \text { TMB solution, } 2 \% \mathrm{v} / \mathrm{v} \mathrm{H}_{2} \mathrm{O}_{2} \\
(3.5 \%) \text { in Substrate buffer }\end{array}$ \\
\hline Stop solution & $1 \mathrm{M} \mathrm{H}_{2} \mathrm{SO}_{4}$ \\
\hline
\end{tabular}

\subsubsection{Nitric oxide assay (NO assay)}

I used the selfmade reagents for NO assay, $1 \%$ sulfanilamide and $1 \%$ Naphthyl.

\subsubsection{Quantitative polymerase chain reaction (qPCR)}

I used the premix Power SYBR $\AA$ Green PCR master supplied by life Technology ${ }^{\top \mathrm{M}}$. For detection gene expression, I used the following primers:

\begin{tabular}{|c|l|}
\hline Gene & Sequence 5' -3' $^{\prime}$ \\
\hline \multirow{2}{*}{ HPRT } & forward: GTCCTGTGGCCATCTGCCTA \\
\cline { 2 - 2 } & reverse: GGGACGCAGCAACTGACATT \\
\hline \multirow{2}{*}{ iNOS } & forward: CCGCACCCGAGATGGTCAGG \\
\cline { 2 - 2 } & reverse: GCAAGGCTGGGAGGGGTCCT \\
\hline \multirow{2}{*}{ Gilz } & forward: TTCCGGGGTTTCCGGGGTTTC \\
\cline { 2 - 2 } & reverse: GTGAGAGAGGAGGTGGAG \\
\hline \multirow{2}{*}{ TNFa } & forward: CGTCAGCCGATTTGCTATCT \\
\cline { 2 - 2 } & reverse: CGGACTCCGCAAAGTCTAAG \\
\hline
\end{tabular}




\begin{tabular}{|c|c|}
\hline \multirow{2}{*}{ INFY } & forward: ACTGGCAAAAGGATGGTGAC \\
\hline & reverse: TGAGCTCATTGAATGCTTGG \\
\hline \multirow{2}{*}{ Fizz1 } & forward: TGCTGGGATGACTGCTACTG \\
\hline & reverse: CTGGGTTCTCCACCTCTTCA \\
\hline \multirow{2}{*}{ CD163 } & forward: TGGTCCAGGAACTGGGCCCA \\
\hline & reverse: GGGTGGGGTGACCTGTGCCA \\
\hline \multirow{2}{*}{ F13a1 } & forward: CCTGCGTACTCGAAGAGACC \\
\hline & reverse: CTTCGAACTGGCCATAGCTC \\
\hline \multirow{2}{*}{ Arginase 1} & forward: AGCCCGAGCACATGCAGCAG \\
\hline & reverse: ACCCCTCCTCGAGGCTGTCCT \\
\hline \multirow{2}{*}{ Ym1 } & forward: ACTTTGATGGCCTCAACCTG \\
\hline & reverse: AATGATTCCTGCTCCTGTGG \\
\hline \multirow{2}{*}{ Msr2 } & forward: AGACCCCAGGAACACTGATG \\
\hline & reverse: GTTCCCAGAGAGTGGAGCTG \\
\hline \multirow{2}{*}{ IL-1b } & forward: AGCTTCCTTGTGCAAGTGTCT \\
\hline & reverse: GCAGCCCTTCATCTTTTGGG \\
\hline \multirow{2}{*}{ IL-6 } & forward: TCTCTGCAAGAGACTTCCATCC \\
\hline & reverse: AGACAGGTCTGTTGGGAGTG \\
\hline \multirow{2}{*}{ IL-17A } & forward: TCCTAACGTTGCGGGGGAGGGC \\
\hline & reverse: AGCATCTTCTCGACCCTGAA \\
\hline
\end{tabular}




\section{Methods}

\section{1 $M^{\text {flox/flox }}$ and $M R^{\text {lysMcre }}$ mice}

All animal experiments were performed with consideration of the necessary legal requirements. Mice were kept under specific pathogen-free conditions (SPF) in individually ventilated cages (IVC). They were fed with food and water ad libitum and maintained in a standard 12 hour day-night cycle.

The generation of the $\mathrm{MR}^{\text {floxflox }}$ and $\mathrm{MR}^{\text {lysMcre }}$ mice was described in Berger et al., 2005. The both genotypes, the exon 3 of MR gene was flanked with flox/flox. But only in the MR ${ }^{\text {lysMcre }}$ mice, the recombinase was expressed by LysM promoter, which is specific for myeloid cells. Hence, in the MR ${ }^{\text {lysMcre }}$ mice the exon 3 of MR gene is removed by recombinase leading to non-sufficient $M R$ transcription, while in the $M R^{\text {floxflox }}$ mice the MR gene transcription is not altered.

\subsection{Induction and analysis of EAE}

\subsubsection{Induction of EAE}

Mice were immunized with $50 \mu \mathrm{g}$ of $\mathrm{MOG}_{35-55}$ peptide in PBS, emulsified in an equal volume of CFA containing Mycobacterium tuberculosis H37RA (Difco) at a final concentration of $1 \mathrm{mg} / \mathrm{ml}$, and given s.c. into the flanks as previously described. Two injections of pertussis toxin (List Biological Laboratories; 400ng/mouse in total) were given, one immediately after immunization and the second 2 days after immunization. 


\subsubsection{Bodyweight and clinical scoring}

Animals were weighed and scored daily for clinical signs of the disease on a scale from 0 to 10 depending on its severity; scores were as followed: $0=$ normal; 1 = reduced tone of tail; 2 = limp tail, impaired righting; $3=$ absent righting; $4=$ gait ataxia; $5=$ mild paraparesis of hindlimbs; $6=$ moderate paraparesis; $7=$ severe paraparesis or paraplegia; $8=$ tetraparesis; $9=$ moribund; $10=$ death .

\subsubsection{Isolation of spinal cord infiltrating macrophages}

EAE mice were sacrificed on day 24 with $\mathrm{CO}_{2}$ and perfused through the left ventricle with physiological saline $(0.9 \%)$ until the effluent ran clear. Vertebral canal was opened with scissors and spinal cords were carefully taken out and subsequently rinsed in PBS. Spinal cords were forced through 100-mesh stainless steel screens to give a single-cell suspension. The spinal cord homogenate were washed with centrifuge at $500 \mathrm{~g}$ and $22{ }^{\circ} \mathrm{C}$ for $20 \mathrm{~min}$, after discarding supernatant pellet was resuspended in $30 \%$ Percoll. During the wash a percoll gradient was set up with two concentrations, $45 \%$ and $70 \%$ percoll, in $15 \mathrm{ml}$ falcon. The resuspension was loaded on the surface of the gradient with needle carefully. The gradients were centrifuged at $1000 \mathrm{~g}$ and from $22^{\circ} \mathrm{C}$ cooled to $4^{\circ} \mathrm{C}$ for 30 min. CNS mononuclear cells were collected from the $30 \% / 70 \%$ interface, washed, and resuspended in PBS, washed, and directly lysed for RNA preparation.

\subsubsection{Immunohistochemistry}

EAE mice were sacrificed with $\mathrm{CO}_{2}$ and perfused through the left ventricle with physiological saline $(0.9 \%)$ until the effluent ran clear and 
subsequently perfused with $4 \%$ paraformaldehyde. Vertebral canal was opened with scissors and spinal cords were carefully taken out and subsequently rinsed in $4 \%$ paraformaldehyde for $24 \mathrm{~h}$, then rinsed in PBS. Spinal cord was then embedded in paraffin and cut into slide. Spinal cord cross-sections were stained with Luxol fast Blue (LFB) to assess demyelination, macrophages/microglia by rat anti-mouse Mac-3 (BD Pharmingen, 1:200), T lymphocytes by anti-mouse CD3 (BD Pharmingen, $1: 200)$.

\subsection{Isolation of peritoneal macrophages (PM)}

Mice were interperitoneal injected with $3 \%$ thioglycolate. On the $4^{\text {th }}$ day after injection, mice were sacrificed and the peritoneal cavity was washed with ice cold PBS+0.1\% BSA with $2 \mathrm{ml}$ for 3 times. The washed out cells were centrifuged at $350 \mathrm{~g}$ for $6 \mathrm{~min}$ and then resuspended and cultured in DMEM in $10 \mathrm{~cm}$ suspension culture plate, at $20^{\circ} \mathrm{C}$ for $4 \mathrm{~h}$. Then the medium and non-adherent cells were discarded and the adherent cells, representing mostly PMs, were incubated with enzyme free dissociation buffer at $4{ }^{\circ} \mathrm{C}$ for $20 \mathrm{~min}$ and subsequently washed off with PBS $+0.1 \%$ BSA. The macrophages were washed again with centrifuge at $350 \mathrm{~g}$ for 6 min. The pellet was resuspended in $1 \mathrm{ml}$ PBS and counted.

\subsection{Bone marrow derived macrophages (BMDMs)}

\subsubsection{Production of L929-cell conditioned medium (LCCM)}

LCCM was produced as described by Ladner et al.. In brief, L929 mouse fibroblasts were grown in DMEM until confluent. Then the supernatant was collected and replaced every two days. The resulting, medium was filtered 
sterile and stored at $-20^{\circ} \mathrm{C}$. For use, it was diluted 1:5 with DMEM (Ladner et al., 1988).

\subsubsection{Cultivation of BMDMs}

Mice were sacrificed with $\mathrm{CO}_{2}$. Tibia and femur were removed, cleaned from flesh and tendons and placed in ice cold PBS with 0.1\% BSA. The ends of the bones were opened under sterile conditions and bone marrow was flushed out using a $30 \mathrm{G}$ needle. Afterwards the cells were passed through a $40-\mu \mathrm{m}$ cell strainer. After wash, the cells were resuspended in 30 $\mathrm{ml}$ LCCM and incubated overnight in a $175 \mathrm{ml}$ cell culture flask per mouse at $37^{\circ} \mathrm{C}$. Adherent cells were discarded and non-adherent cells were transferred to $10 \mathrm{ml}$ suspension culture plates ( $5 \mathrm{ml}$ cell suspension/plate). In each plate medium was added to $10 \mathrm{ml}$. After 5 days, another $5 \mathrm{ml}$ of fresh LCCM were added. On day 9, the cells were washed with PBS and removed using $1 \mathrm{ml}$ enzyme free dissociation buffer/plate and incubated at $4{ }^{\circ} \mathrm{C}$ for $20 \mathrm{~min}$. Then the cells were washed off using PBS+0.1\% BSA. The suspension was washed at $350 \mathrm{~g}, 6 \mathrm{~min}$, at $4{ }^{\circ} \mathrm{C}$. The pellet was resuspended in $1 \mathrm{ml}$ DMEM and counted under microscope.

\subsection{Phagocytosis assay}

On the first day, lymph nodes (lymphnodi madibulares, axillares accessorii, inguinales superficiales, mesenteriales) were took out from BALB/c mice that were sacrificed with $\mathrm{CO}_{2}$. Lymphocytes were obtained by passing the lymph nodes through cell strainer with a $40 \mu \mathrm{m}$ nylon mesh. The lymphocytes were washed once at $350 \mathrm{~g}$ for $6 \mathrm{~min}$ at $4{ }^{\circ} \mathrm{C}$. Then, the lymphocytes were resuspended in PBS with cell density of $10^{6} \mathrm{cell} / \mathrm{ml}$. Per $\mathrm{ml}$ cell suspension was added with $0.05 \mu \mathrm{l}$ mM CFSE and warmed in 
water bath at $37^{\circ} \mathrm{C}$ for $10 \mathrm{~min}$. Subsequently, per $\mathrm{ml}$ suspension was added $0.02 \mathrm{ml} \mathrm{FCS}$ and centrifuged at $350 \mathrm{~g}$ for $10 \mathrm{~min}$ at $4{ }^{\circ} \mathrm{C}$. The cell pellet was resuspended in $2 \mathrm{ml} \mathrm{PBS}$ and irradiated at $5 \mathrm{gray} / \mathrm{min}$ for $6 \mathrm{~min}$. After irradiation, the cell amount was counted again and distributed in 48 well/plate with $2 \times 10^{5}$ cell/well. Each well was filled with $500 \mu$ I DMEM.

On the second day, macrophages were counted and at ration 2:1 (Macrophage:lymphocyte) added to the preseeded lymphocytes. Each well was filled to $1 \mathrm{ml}$ with DMEM and the plate was incubated at $37^{\circ} \mathrm{C}$. To determine the phagocytotic activity, the cell mixture was resuspended with Eppendorf $\circledast$ pipette and $500 \mu \mathrm{l}$ mixture was took to determine the phagocytotic activity by FACS. On FACS, macrophage population was gated according to FSC and SSC. The lymphocytes should be apoptosed after irradiation in $24 \mathrm{~h}$.

\subsection{Quantitative polymerase chain reaction (qPCR)}

\subsubsection{Isolation of RNA from cells}

RNA was isolated using the Quick-RNA ${ }^{\mathrm{TM}}$ Mini-Prep supplied by the Epigenetics ${ }^{\circledR}$ Company Plus Universal Kit according to manufacturer's instructions. The cells were homogenized and lysed by $600 \mu \mathrm{l}$ RTL buffer and subsequently centrifuged at $12,000 \mathrm{~g}$ for $1 \mathrm{~min}$ at $22{ }^{\circ} \mathrm{C}$, through column supplied. Then, the column was washed once with $400 \mu \mathrm{l}$ pre-wash buffer at $12,000 \mathrm{~g}$ for $1 \mathrm{~min}$ at $22{ }^{\circ} \mathrm{C}$, and twice at $12,000 \mathrm{~g}$ for 30 s at $22{ }^{\circ} \mathrm{C}$ each with $700 \mu \mathrm{l}$ and $400 \mu \mathrm{l}$ wash buffer containing $70 \%$ ethanol. Then, the column was placed in a new $1.5 \mathrm{ml}$ Eppendorf $\circledast$ tube and $30 \mu \mathrm{l}$ nuclease-free water was added into the middle of the column. After 1 min incubation at RT, RNA was eluted from the column by centrifuging at $20,000 \mathrm{~g}$ for $1 \mathrm{~min}$ at $22{ }^{\circ} \mathrm{C}$. 


\subsubsection{Reverse transcription from RNA to CDNA}

For cDNA synthesis the iScript cDNA Synthesis Kit was used according to manufacturer's instructions. Approximately $1 \mu \mathrm{g}$ RNA was mixed with $4 \mu \mathrm{l}$ 5x iScript Reaction Mix, $0.25 \mu \mathrm{l}$ iScript Reverse Transcriptase and $14.75 \mu \mathrm{l}$ nuclease-free water. The mixture was incubated at $25{ }^{\circ} \mathrm{C}$ for $5 \mathrm{~min}$, subsequently, at $42{ }^{\circ} \mathrm{C}$ for $30 \mathrm{~min}$, and finally at $85^{\circ} \mathrm{C}$ for $5 \mathrm{~min}$.

\subsubsection{Quantitative PCR (qPCR)}

$1 \mu \mathrm{l} \mathrm{CDNA}$ was mixed with $12.5 \mu \mathrm{l}$ SYBR green, $0.5 \mu \mathrm{l}$ primer mix and $11 \mu \mathrm{l}$ $\mathrm{ddH}_{2} \mathrm{O}$ in each well of a 96-well optical reaction plate. The plate was sealed with an optical adhesive cover and shortly centrifuged. qPCR was run with the applied Biosystems 7500 real time PCR system using 7500 system SDS software. The $\Delta \Delta$ ct was calculated automatically by the software.

\subsection{Enzyme linked immunosorbant Assay (ELISA)}

TNF $\alpha$ production by macrophages was analysed with ELISA in cell medium. ELISA was performed with BD Biosciences kit and according to manufacturer's instructions.

96-well plates were coated with capture antibody overnight at $4{ }^{\circ} \mathrm{C}$ using the appropriate coating buffer. The following steps on the second day were performed under RT. After washing with wash buffer, plates were blocked with assay diluents for $1 \mathrm{~h}$. Washing was repeated and plates were incubated for $1 \mathrm{~h}$ with detection antibody and enzyme reagent diluted in assay diluents. Washing was then performed leaving the wells to soak for 
$30 \mathrm{~s}$ and finally the plate was incubated for 20 min with substrate solution. The reaction was stopped with stop solution and then measured at $450 \mathrm{~nm}$ and $570 \mathrm{~nm}$.

\subsection{Nitric oxide assay (NO assay)}

NO assay was performed in 96-well ELISA plate with BMDMs. After harvesting BMDMs, $2 \times 10^{5}$ BMDMs were seeded in each well with $200 \mu \mathrm{l}$ DMEM with LPS $(0.15 \mathrm{ng} / \mu \mathrm{l})$, and duplicated $4 x$ per mouse. Two wells were added with $10^{-7} \mathrm{M}$ Dex or PBS as control. The plate was incubated at $37^{\circ} \mathrm{C}$ for $48 \mathrm{~h}$. Then $50 \mu \mathrm{l}$ supernatant was transferred in corresponding wells in ELISA plate. Concentration series of $\mathrm{NaNO}_{2}$ solution, $500 \mathrm{mM}$, $250 \mathrm{mM}, 125 \mathrm{mM}, 62.5 \mathrm{mM}, 31 \mathrm{mM}, 15.5 \mathrm{mM}, 7.8 \mathrm{mM}, 3.9 \mathrm{mM}, 1.95 \mathrm{mM}$, $0 \mathrm{mM}$ were used to determine the NO concentration in medium. $50 \mu \mathrm{l} 1 \%$ sulfanilamide was added to each well. After 5 min incubation, $50 \mu \mathrm{l} 1 \%$ Naphthyl was added to each well. After gentle shaking, the plate was measured at $540 \mathrm{~nm}$.

\subsection{Flow cytometry (FACS)}

For standard FACS-analysis $4 \times 10^{5}$ cells were used. All samples were analysed using a FACS Cantoll and FlowJo. If staining samples was necessary, samples were incubated with primary antibodies for 20 min, washed with $4 \mathrm{ml}$ FACS buffer. After discarding supernatant, cells were vortexed in reflux before measuring. 


\subsection{0 shRNA Cloning}

\subsubsection{Mutagenesis PCR}

The primers were designed by myself and synthesized by Metabion®. The reaction reagent was pipetted in PCR tube according to the schema below:

\begin{tabular}{|c|c|}
\hline Reagent & Volume $(\mu \mathrm{l})$ \\
\hline Template & 0.2 \\
\hline Primer forward & 0.2 \\
\hline Primer reverse & 0.2 \\
\hline Phusion® polymerase & 0.5 \\
\hline Invitrogen $\AA$ PCR buffer & 10 \\
\hline $5 x$ & 1 \\
\hline Invitrogen $\AA$ dNTP & 37.9 \\
\hline $\mathrm{ddH}_{2} \mathrm{O}$ & \\
\hline
\end{tabular}

The PCR was performed in Eppendorf® thermocycler with the program:

\begin{tabular}{|c|c|c|}
\hline step & Temperature $\left({ }^{\circ} \mathrm{C}\right)$ & Time $(\mathrm{min})$ \\
\hline 1 & 98 & 3 \\
\hline 2 & 98 & 0.5 \\
\hline 3 & $\mathrm{~T}_{\mathrm{m}}{ }^{*}$ & 0.5 \\
\hline 4 & 72 & 0.5 \\
\hline 5 & Go to step 2, 30x & \\
\hline 6 & 72 & 5 \\
\hline 7 & 10 & $\sim$ \\
\hline
\end{tabular}

*: the actual annealing temperature was set $1^{\circ} \mathrm{C}$ higher than the lower $\mathrm{T}_{\mathrm{m}}$ of the primer pair, to exclude the non-specific primer-template binding. 


\subsubsection{Ligation}

All ligation reactions were sticky ends ligation and performed under RT by using NEB® $\mathrm{T} 4$ ligase and the supplied ligase buffer 10x. Opened plasmid was mixed with cloning DNA fragment in an approximate ration of substance amount 1:3. Each reaction volume was set to $10 \mu$, including 1 $\mu \mathrm{l}$ ligase buffer 10x and $0.5 \mu \mathrm{l}$ T4 ligase. The rest volume was added by $d_{d d} H_{2} \mathrm{O}$. The mixture was than incubated at $\mathrm{RT}$ for $2 \mathrm{~h}$, and then completely used for transformation in E.coli.

\subsubsection{Plasmid amplification}

Plasmid was amplificated according to further experiment request either by mini-, midi-, or maxi-preparation.

Mini-preparation was used for detect the positively transformed E.coli clone. On the second day of transformation 3-6 E.coli colonies were randomly picked and cultured in $3 \mathrm{ml}$ anti-biotic containing LB medium at $37^{\circ} \mathrm{C}$ overnight with shaking. In the next morning, $2 \mathrm{ml}$ E.coli culture was discarded in $2 \mathrm{ml}$ Eppendorf $\circledast$ tube and centrifuged at $350 \mathrm{~g}$ for $5 \mathrm{~min}$ at $4{ }^{\circ} \mathrm{C}$. After discarding supernatant, the cell pellet was resuspended in self-made $300 \mu \mathrm{l} \mathrm{P1}$ buffer, subsequently lysed with $300 \mu \mathrm{l}$ P2 buffer and the tube was inverted 4-6 times. After 5 min incubation, $300 \mu$ P3 buffer was immediately added into the tube. The tube was inverted 4-6 times and then placed at $4{ }^{\circ} \mathrm{C}$ for $15 \mathrm{~min}$. Then the tube was centrifuged at $20,000 \mathrm{~g}$ for $15 \mathrm{~min}$ at $4{ }^{\circ} \mathrm{C}$. The supernatant was collected in a new $1.5 \mathrm{ml}$ Eppendorf $\circledast$ tube and added with $600 \mu$ isopropanol. After inverting, the tube was centrifuged at $20,000 \mathrm{~g}$ for $10 \mathrm{~min}$ at $4{ }^{\circ} \mathrm{C}$. Then, the supernatant was completely removed and $500 \mu \mathrm{l} 70 \%$ Ethanol was gently added to wash the pellet, and immediately centrifuged at $20,000 \mathrm{~g}$ for 5 min at $4{ }^{\circ} \mathrm{C}$. The supernatant was removed carefully and the pellet was dried in 
thermoblock at $65{ }^{\circ} \mathrm{C}$. The dried pellet was dissolved in $30 \mu \mathrm{lddH} 2 \mathrm{O}$ and the DNA concentration was determined by Eppendorf $\circledast$ Nanodrop.

In case of midi- and maxi-preparation, appropriate kits from Qiagen® were used. All procedures were performed according to manufacturer's instructions. The whole E.coli culture was centrifuged at $500 \mathrm{~g}$ for $15 \mathrm{~min}$ at $4{ }^{\circ} \mathrm{C}$. The pellet was resuspended in 4 and $10 \mathrm{ml} \mathrm{H} 1$ buffer, and subsequently lysed in 4 and $10 \mathrm{H} 2$ buffer, after 5 min was added with 4 and $10 \mathrm{ml} \mathrm{H} 3$ buffer, respectively. The mixture was loaded to QIAfilter cartridge and incubated for $10 \mathrm{~min}$ at RT. Then the mixture was pushed through the filter into an anion-exchange tip, where the DNA was washed and purified. DNA elution was performed by adding 5 and $10 \mathrm{ml}$ nuclease-free water, respectively. DNA was further purified with isopropanol and $70 \%$ ethanol similar to mini-preparation.

\subsection{Western blot}

Cell extracts were obtained same amount of cells and their lysis in a buffer containing $1 \%$ Nonidet P- $40,0.1 \%$ SDS, and $0.5 \%$ sodium deoxycholate in PBS. A protease inhibitor mixture was added before extraction (Roche). The lysates were fractionated on a SDS-PAGE gel and blotted for $1 \mathrm{~h}$ at $160 \mathrm{~mA}$ using a semidry device. Western blot analysis was performed by antibody incubation in PBS containing $0.1 \%$ Tween and $5 \%(\mathrm{w} / \mathrm{v}) \mathrm{BSA}$ on shaker at RT. The following primary antibodies were used in this study: anti-MR (ABcam, 1:1,000 dilution), Sirt1 (Sant Cruz; 1:1,000 dilution), GR (Santa Cruz, 1:1,000 dilution). Goat anti-rabbit IgG-HRP and goat anti-mouse IgG-HRP (Dianova) were used as secondary antibodies and self made solution $A$ and $B$ were used for developing. 


\subsection{Cell culture}

\subsubsection{HEK293 cell culture}

HEK293 cells were cultured in DMEM in culture dish. After $80 \%$ confluent the cells were detachted with trypsin, $0.5 \mathrm{ml}$ and $1 \mathrm{ml}$ for $5 \mathrm{~cm}$ and $10 \mathrm{~cm}$ dish, respectively. The cells with trypsin were incubated at $37^{\circ} \mathrm{C}$ for $1 \mathrm{~min}$ and immediately washed with $10 \mathrm{ml}$ DMEM. After centrifugation the cell pallet was resuspended with $10 \mathrm{ml}$ DMEM and placed $1 \mathrm{ml}$ in a new dish with $9 \mathrm{ml}$ fresh medium.

\subsubsection{Generation of MR overexpressing cells}

I used HEK293 cells for generating MR overexpressing cells. MR cDNA was cloned in pcDNA3 plasmid. $\mathrm{Ca}_{3}\left(\mathrm{PO}_{4}\right)_{2}$ precipitation was used to transfect the MR encoding vector into HEK293 cells. $10^{6}$ HEK293 cells were seeded in $6 \mathrm{~cm}$ dish in $4 \mathrm{ml}$ transfection medium and incubated at $37^{\circ} \mathrm{C}$ for 4 h. $20 \mu \mathrm{g}$ MR containing vector was mixed with $\mathrm{Na}_{2} \mathrm{HPO}_{4}(\mathrm{pH}$ 6.8) and added with $\mathrm{ddH}_{2} \mathrm{O}$ to $500 \mu \mathrm{l}$, and subsequently dropwise mixed with $500 \mu \mathrm{l} 50 \mathrm{mM} \mathrm{CaCl}_{2}$ accompanying vortex. Subsequently, the mixture was equally distributed to the cells and incubated at $37^{\circ} \mathrm{C}$ overnight. On the second day, medium was replaced by $5 \mathrm{ml}$ fresh BMDM. After confluent, cells were detached, washed and resuspended in $40 \mathrm{ml}$ fresh BMDM with $3 \mu \mathrm{g} / \mathrm{ml}$ puromycin, then, distributed in two 98-well tissue culture plates. Since the $3^{\text {rd }}$ weed, only the cell colonies, which were as the single colony in well and observed by naked eye, were detached and expanded in 6-well tissue plate with $2 \mathrm{ml}$ fresh BMDM with $3 \mu \mathrm{g} / \mathrm{ml}$ puromycin. The medium with antibiotic was replaced every day. After confluent, the half cells were used for western blot to test the MR 
expression, and the rest of cells were cultured further in new plate. Following, only the cell clone that expressed the most MR protein was reserved for the MR knockdown test.

\subsubsection{C2C12 cell culture}

C2C12 cells were cultured in DMEM in culture dish. After $80 \%$ confluent the cells were detachted with trypsin, $0.5 \mathrm{ml}$ and $1 \mathrm{ml}$ for $5 \mathrm{~cm}$ and $10 \mathrm{~cm}$ dish, respectively. The cells with trypsin were incubated at $37^{\circ} \mathrm{C}$ for $1 \mathrm{~min}$ and immediately washed with $10 \mathrm{ml}$ DMEM. After centrifugation the cell pallet was resuspended with $10 \mathrm{ml}$ DMEM and placed $1 \mathrm{ml}$ in a new dish with $9 \mathrm{ml}$ fresh medium.

\subsubsection{Mouse embryonic fibroblast (MEF)}

MEF cells were cultured in DMEM in culture dish. After $80 \%$ confluent the cells were detachted with trypsin, $0.5 \mathrm{ml}$ and $1 \mathrm{ml}$ for $6 \mathrm{~cm}$ and $10 \mathrm{~cm}$ dish, respectively. The cells with trypsin were incubated at $37^{\circ} \mathrm{C}$ for $1 \mathrm{~min}$ and immediately washed with $10 \mathrm{ml}$ DMEM. After centrifugation the cell pallet was resuspended with $10 \mathrm{ml}$ DMEM and placed $1 \mathrm{ml}$ in a new dish with 9 $\mathrm{ml}$ fresh medium.

\subsection{Procedures with lentivirus (Under S2 condition)}

\subsubsection{Lentivirus production}

Lentiviral particles were produced by transfecting HEK293 cells seeded in 6 -cm dishes with plasmids- $\mathrm{Ca}_{3}\left(\mathrm{PO}_{4}\right)_{2}$ precipitation. To produce the 
precipitation, $10 \mu \mathrm{g}$ of vector DNA together with three helper plasmids ( 5 $\mu \mathrm{g}$ of pMDL-RRE, $2.5 \mu \mathrm{g}$ of pRSV-REV, and $3 \mu \mathrm{g}$ of pVSV-g, all the amounts are portioned for one dish.) were mixed with $\mathrm{Na}_{2} \mathrm{HPO}_{4}(\mathrm{pH}$ 6.8) and added with $\mathrm{ddH}_{2} \mathrm{O}$ to $500 \mu \mathrm{l} .500 \mu \mathrm{l} 50 \mathrm{mM} \mathrm{CaCl}_{2}$ was dropwise added to the mixure accompanying vortex. Subsequently, the precipitation was added to HEK293 cells. After 8h, the medium was aspirated with $4 \mathrm{ml}$ fresh, prewarmed medium and added with $8 \mu \mathrm{M}$ butyrate. The virus-containing cell culture supernatants were collected $48 \mathrm{~h}$ after transfection, passed through a $0.45-\mu \mathrm{m}$ filter, and be ready for direct knockdown test in cell culture or further ultraconcentration.

\subsubsection{Concentrating lentivirus by Ultracentrifugation}

The virus-containing cell culture supernatants were collected $48 \mathrm{~h}$ after transfection, passed through a $0.45-\mu \mathrm{m}$ filter, and concentrated by centrifugation in Beckermann® Tube, filled with medium to remove the bubbles, for $2 \mathrm{~h}$ at $26,000 \mathrm{~g}$ at $4{ }^{\circ} \mathrm{C}$. The virus pellet was subsequently resusupended in $10 \mu \mathrm{l}$ of $\mathrm{PBS} / 0.1 \%$ BSA for 48 hours and subsequently frozen in $6 \mu \mathrm{l} /$ aliquot at $-80^{\circ} \mathrm{C}$.

\subsubsection{Titration}

In order to circumvent the freezing-thawing influence on virus infectious ability, to all titration tests the virus was first treated once through freezing-thawing. On the titration day, $10^{4} \mathrm{HEK} 293$ cells/well were seeded in 12-well plate. For each viral construct, six wells are required. After thawing, the virus aliquot was 1:100 diluted and titrated to the cells in volumes: $300 \mu \mathrm{l}, 100 \mu \mathrm{l}, 30 \mu \mathrm{l}, 10 \mu \mathrm{l}, 3 \mu \mathrm{l}, 1 \mu \mathrm{l}$. Then the plate was incubated at $37^{\circ} \mathrm{C}$ for 3 days. On the $3^{\text {rd }}$ day after titration, the cells were detached by trypsin and washed once with 4 ml FACS buffer. 
Subsequently, the EGFP positive cell population was determined by FACS.

\subsection{4 shRNA functional test in vitro}

$3 \mathrm{ml}$ filtrated virus-containing medium was mixed with $1 \mathrm{ml}$ fresh DMEM and added to C2C12 cells, MR overexpressing HEK293 cells and MEF cells for shSirt1, shMR and shGR test, respectively. Four days after infecetion cells were detached, and the half cells were used to be analyzed for infection ratio by FACS. The cell population over $80 \%$ infected was kept in culture for further test. Till confluent, cells were splited in two $6 \mathrm{~cm}$ dishes. One dish was treated with Doxycycline to concentration $2 \mu \mathrm{g} / \mathrm{ml}$, the other one was treated with PBS as control. Medium and regency were aspirated every day. After three days treatment, the cells were detached and counted. The same amount cells were lysed as described in "Western blot". Following, the shRNA knockdown efficiency was compared by western blot. 


\section{Results}

\subsection{Characterization of bone marrow derived macrophages (BMDMs) in $M^{\text {lysMcre }}$ mice}

\subsubsection{Efficiency of MR ablation in macrophages}

In order to check the MR knockout efficiency in used BMDMs population the levels of MR mRNA from the cells harvested from BMDMs culture were compared with qPCR (Figure 2). I compared the MR gene expression in $M R^{\text {lysMcre }}$ and $M^{\text {flox/flox }}$ samples by setting the later one's mean value as $100 \%$. The MR gene expression was strongly reduced in MR $R^{\text {lysMcre }}$ samples, around $80 \%$ less than in $\mathrm{MR}^{\text {flox/flox }}$ samples.

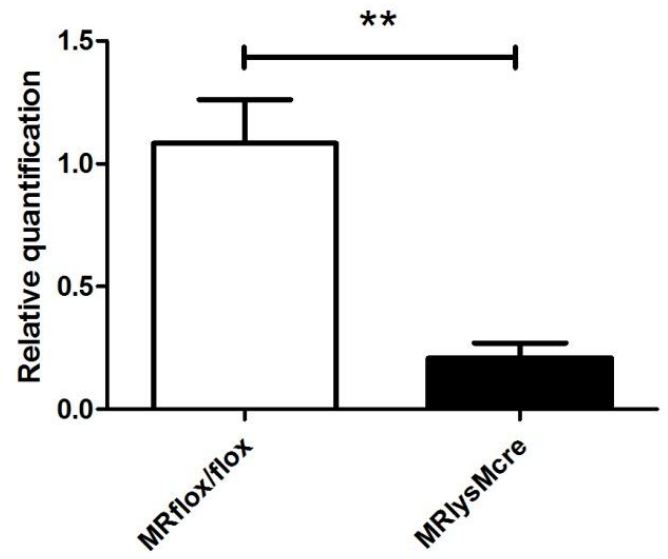

Figure 2: The MR knockout efficiency in BMDMs. Mouse bone marrow was resuspended and cultured in LCCM for differentiation to BMDM; After 8 days RNA was isolated from the differentiated BMDMs and reverse transcribed to CDNA; The expression levels of MR mRNA were measured by GPCR using primers, which bind to the junction between exon 3 and exon 4; the relative mRNA expression levels were obtained by normalizing to HPRT mRNA expression; relative expression in $\mathrm{MR}^{\text {floxflox }}$ was set equal to 
$100 \%$; mean values + s.e.m $(n=5)$.

\subsubsection{Relative expression levels of macrophage-specific genes in BMDMs}

To test the effect of myeloid specific MR ablation on fresh derived macrophage polarization, I investigated the gene expression pattern in BMDMs in vitro (Figure 3A, B, C). The BMDMs of both genotypes have similar expression pattern of AAM markers (Figure $3 \mathrm{~A}$ ) and typical proinflammatory cytokines (Figure 3B). Due to the opposed functions of Arginase 1 and iNOS in macrophagesthe, I also compared the expression of these two genes (Figure $3 \mathrm{C}$ ). Arginase1 gene was nearly equally expressed in both macrophage genotypes. Interestingly, the iNOS gene was significantly less expressed in $M^{\text {lys Mcre }}$ than in $M^{\text {floxflox }}$ macrophages. 
A

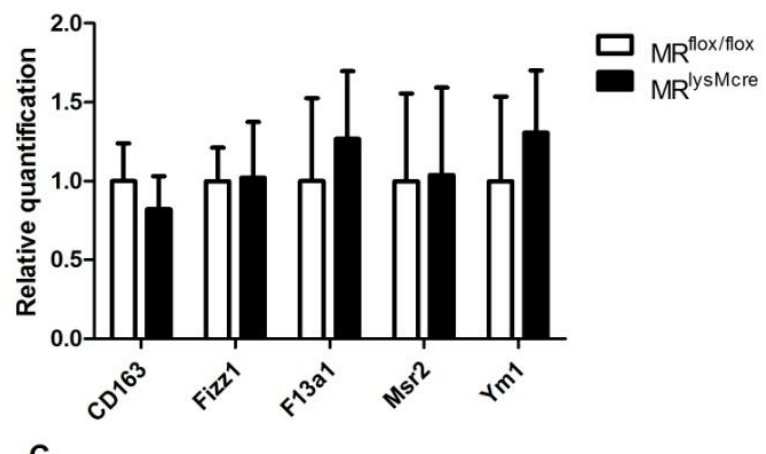

C

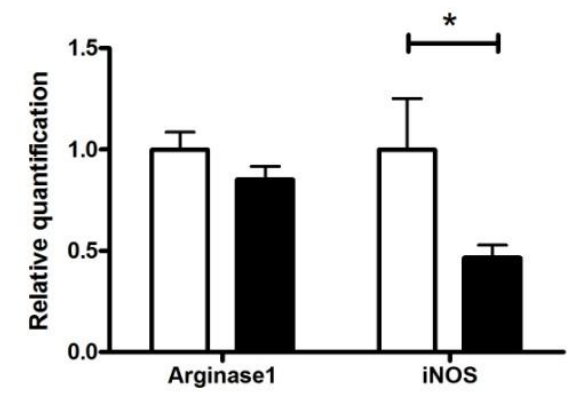

B

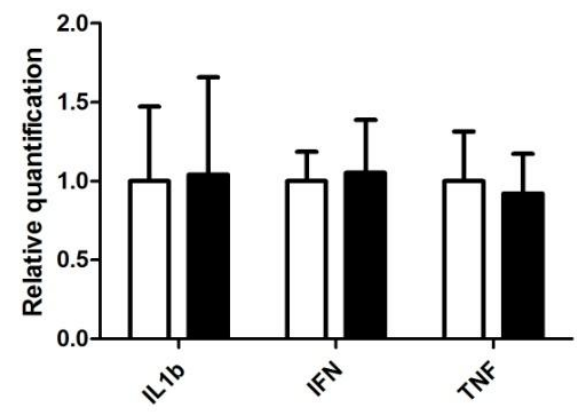

Figure 3: Relative expression levels of macrophage-specific genes. Mouse bone marrow was resuspended and cultured in LCCM for differentiation to BMDM; After 8 days RNA was isolated from the differentiated BMDMs and reverse transcribed to CDNA; relative mRNA expression levels were obtained by normalizing to HPRT mRNA expression; relative expression in $\mathrm{MR}^{\text {floxfllox }}$ was set equal to 1 ; mean values + s.e.m $(n=11-13)$. The relative expression levels of anti-inflammatory genes (A) and pro-inflammatory genes $(B)$ in $\mathrm{MR}^{\text {lysMcre }}$ macrophages are compared to that in $\mathrm{MR}^{\text {floxfllox }}$ macrophages. To highlight the difference between the two genotypes, the relative expression levels of Arginase 1 and iNOS are depictured together (C).

\subsubsection{Phagocytosis assay}

To investigate the effect of the myeloid specific MR knockout on the phagocytotic activity of BMDMs, I performed a phagocytosis assay by mixing BMDMs with CFSE stained and subsequently irradiated lymph nodes cells. After taking up the lymph nodes cells, the BMDMs acquired CFSE and were counted by flow cytometry (Figure 4). The MR ${ }^{\text {lysMcre }}$ 
BMDMs contained a higher CFSE positive population than the $\mathrm{MR}^{\text {flox/flox }}$ BMDMs, suggesting that the $\mathrm{MR}^{\text {lysMcre }}$ BMDMs took up more apoptotic lymph node cells than $\mathrm{MR}^{\text {flox/flox }}$ BMDMs did.

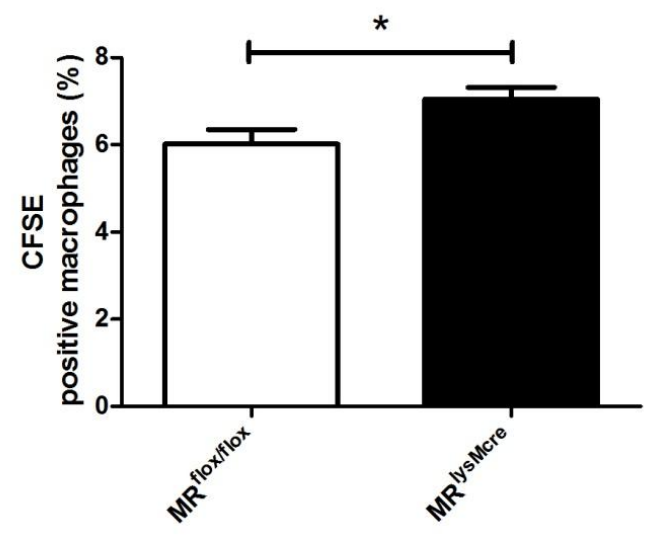

Figure 4: Phagocytotic activity of BMDMs. BMDMs were mixed with CFSE prestained cells isolated from lymph nodes at a ratio of 2:1 (BMDMs:cells); The cell mixtures were collected after $2 \mathrm{~h}$, subsequently measured by flow cytometry; the percentages of CFSE positive macrophages from 4 separated experiments $(n=20-22)$ were determined and depictured in this graph.

\subsubsection{TNFa production by BMDMs after LPS stimulation}

AAMs generally have lower expression of proinflammatory cytokines compared to CAM. To address whether myeloid cell-specific MR ablation polarizes macrophages towards an anti-inflammatory state, I stimulated BMDMs with LPS for $48 \mathrm{~h}$ with or without Dex treatment and measured TNFa production by these cells in vitro (Figure 5). As illustrated, Dex significantly reduced the TNFa production by BMDMs of the both genotypes compared to the group without Dex treatment. The MR $\mathrm{R}^{\text {lysMcre }}$ BMDMs produced almost equal amount of TNFa alone upon LPS stimulation. But after Dex treatment, TNFa production by MR ${ }^{\text {lysMcre }}$ BMDMs was no longer detectable. 


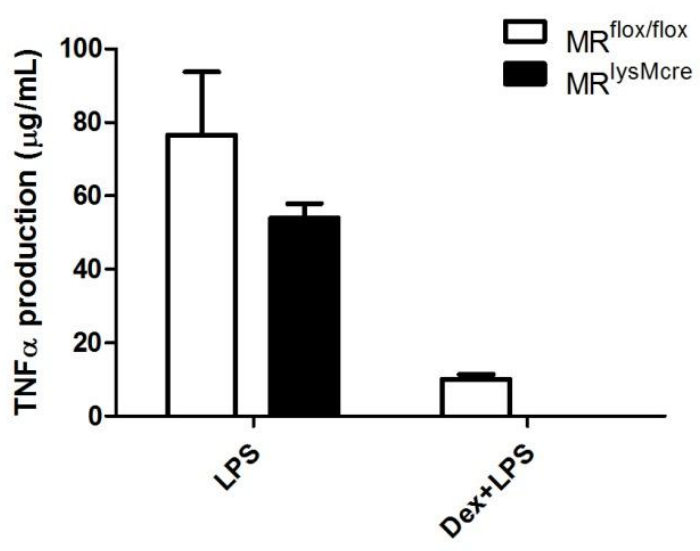

Figure 5: TNFa produced by BMDMs after LPS stimulation. BMDMs were cultured with Dex $10^{-7}$ M or PBS as a control, and stimulated with LPS $(3 \mathrm{ng} / \mathrm{mL})$. Supernatants were collected after $48 \mathrm{~h}$ stimulation and TNFa was measured by ELISA; mean values + s.e.m, $(n=4-6)$.

\subsubsection{NO Production by BMDMs after LPS stimulation}

One of the characteristics of AAM is a higher expression of Arginase1, which competes with iNOS for the substrate L-arginine. The more $\mathrm{L}$-arginine that is converted by Arginase 1 to urin and ornithine, the less NO can be produced by iNOS from L-arginie. To address whether MRlysMcre macrophages acquired this AAM property, I assessed NO production by BMDMs of both genotypes (Figure 6). Similar to the TNFa production pattern, NO production by both genotypes was strongly reduced after Dex treatment. However, MR ${ }^{\text {lysMcre }}$ BMDMs produced significant less NO than $M R^{\text {floxfllox }}$ BMDMs regardless of Dex treatment. 


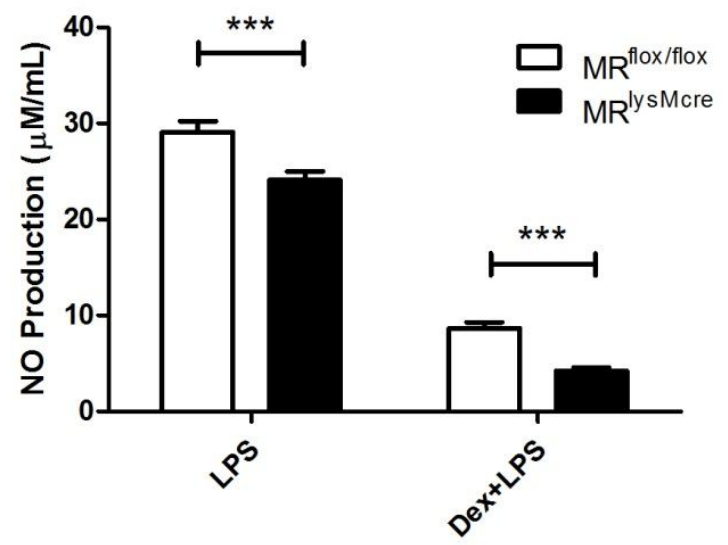

Figure 6: Production of NO by BMDMs after LPS stinulation. BMDMs were cultured with or without $10^{-7} \mathrm{M}$ Dex in 96 -wells plate and stimulated with $3 \mathrm{ng} / \mathrm{mL}$ LPS; Supernatant was collected after $48 \mathrm{~h}$ stimulation and the NO concentration was measured by using the "Griess Reagent system" $(n=10-12)$.

\subsubsection{Relative gene expression of Arginase1 and iNOS in BMDMs after LPS stimulation}

I isolated mRNAs from the BMDMs after 48h stimulation and compared the mRNA levels of Arginase1 and iNOS in both genotypes (Figure 7). The MR ${ }^{\text {lysMcre }}$ BMDMs expressed more Arginase1 and less iNOS in compared to those by $M^{\text {floxfllox }}$ after LPS stimulation. Despite the differences between the two genotypes were not significant, regarding to the opposed effects of these two genes an aggregated effect on NO production could be enormous. 


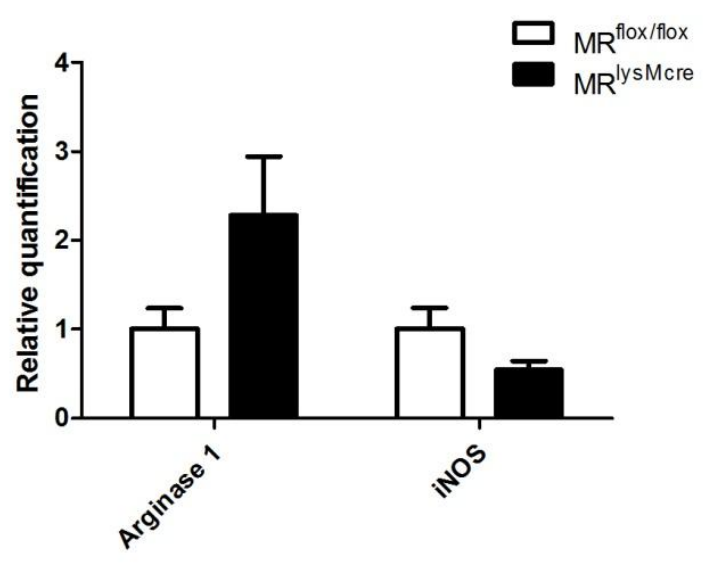

Figure 7: Relative gene expression of Arginase1 and iNOS in BMDMs after LPS stimulation. RNA was isolated from the BMDMs after LPS stimulation and reverse transcript to cDNA for qPCR; relative mRNA expression levels were obtained by normalizing to HPRT mRNA expression; mean values + s.e.m $(n=11-13)$.

\subsection{Characterization of peritoneal macrophages (PMs) in MR ${ }^{\text {lysMcre }}$ mice}

\subsubsection{Relative expression levels of macrophage-specific genes in PMs}

To test the effect of MR deletion on PM polarization, I investigated genes expression pattern in vitro (Figure 8A, B, C). P.M.s of both genotypes had similar expression patterns of AAM markers (Figure 8A) and typical proinflammatory cytokines (Figure 8B). Due to the opposing functions of Arginase 1 and iNOS in macrophages, I also compared gene expression of these two genes (Figure $8 \mathrm{C}$ ). In contrast to BMDMs, MR ${ }^{\text {lysMcre }}$ P.M.s expressed nearly similar levels of Arginase1 and iNOS compared to $M^{\text {flox/flox }} P M s$. 
A

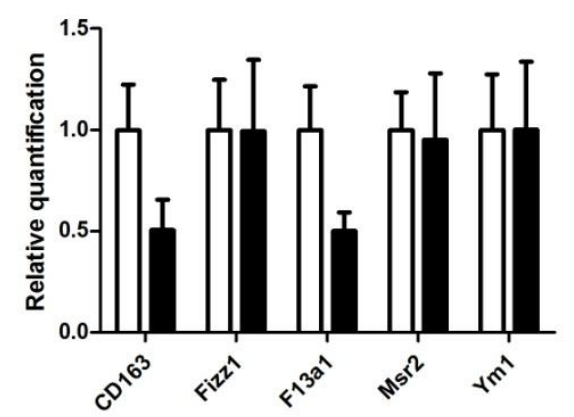

C

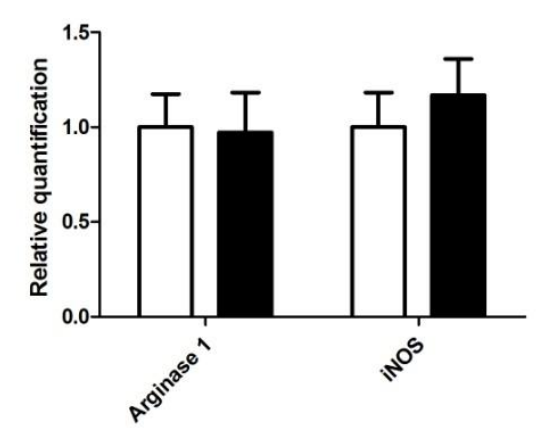

B

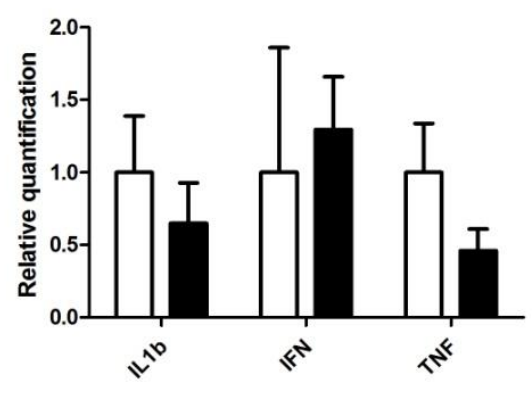

Figure 8: Relative gene expression in PMs. Thiglycollate elicited PMs were collected from peritoneal cavity on day 3 after Thioglycolate injection and used for RNA isolation; the relative mRNA expression levels of AAM markers mRNA were obtained by normalizing to HPRT mRNA transcription; relative expression in $\mathrm{MR}^{\text {floxflox }}$ was set equal to 1 ; mean values + s.e.m, $(n=10-12)$. The relative expression levels of anti-inflammatory genes (A) and pro-inflammatory genes (B) in $\mathrm{MR}^{\text {IysMcre }}$ macrophages are compared to that in $\mathrm{MR}^{\text {floxfllox}}$ macrophages. To highlight the difference between the two genotypes, the relative expression levels of Arginase 1 and iNOS are depictured in one graph (C).

\subsubsection{Phagocytosis assay of PMs}

I performed a phagocytosis assay by mixing PMs with lymph nodes cells, which were CFSE stained and subsequently irradiated. After taking up the lymph nodes cells, the macrophages acquired CFSE and were counted by flow cytometry (Figure 9). The MR ${ }^{\text {lysMcre }}$ macrophages contained a higher 
CFSE positive population than $\mathrm{MR}^{\text {floxflox }}$ macrophages, and the difference between both genotypes was statistically significant, suggesting that MR deletion enhanced the phagocytotic activity in macrophages.

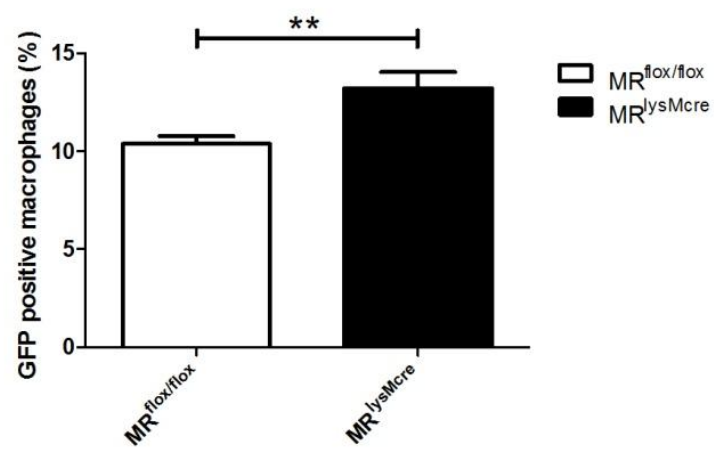

Figure 9: Phagocytotic activity of PMs. Thioglycollate elicted PMs were collected from the peritoneal cavity and mixed with CFSE prestained cells isolated from lymph nodes at a ratio of 2:1 (BMDMs:cells); The cell mixtures were collected after $20 \mathrm{~h}$ and subsequently measured by flow cytometry; the percentages of CFSE positive macrophages from 2 independent experiments $(n=6-7)$ were determined and depictured.

\subsection{Characterization of EAE in MR ${ }^{\text {lysMcre }}$ mice}

\subsubsection{EAE clinical disease curve}

In vitro experiments had shown that MR knockout macrophages acquired some AAM characteristics. To address the question whether $M^{\text {IysMcre }}$ mice benefit from myeloid specific MR ablation in vivo, we chose the EAE disease model. We induced EAE in both $M^{\text {floxflox }}$ and $M R^{\text {lysMcre }}$ mice with $M O_{35-55}$ and $C F A$. Around 7 days after induction we observed first disease symptoms and then scored the mice every day (Figure 10). In the first acute phase the mice from both genotypes EAE developed almost similar disease symptoms (from $9^{\text {th }}$ day to $13^{\text {th }}$ day). In the chronic phase 
(from $14^{\text {th }}$ day to the end), the disease did not aggregate anymore and even slightly recovered in some individuals. In this phase, the $\mathrm{MR}^{\text {lysMcre }}$ mice suffered significantly less from EAE than the $\mathrm{MR}^{\text {floxflox }}$ mice.

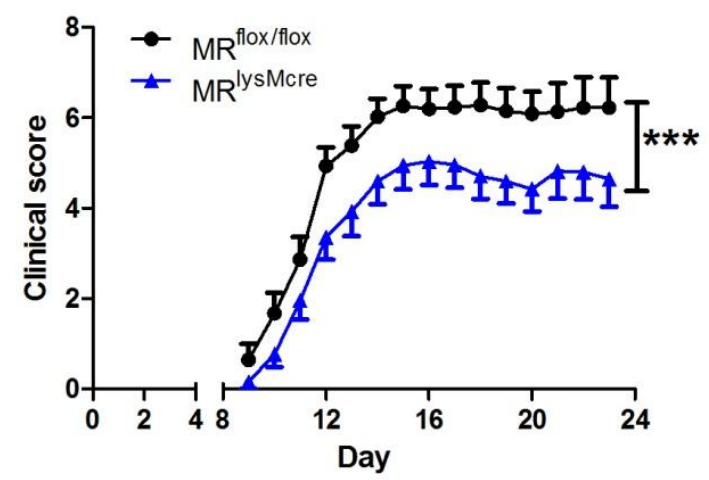

Figure 10: EAE clinical diease curve of $M R^{\text {flox/flox }}$ and $M R^{\text {lysMcre }}$ mice. $E A E$ was induced in $\mathrm{MR}^{\text {floxflox }}$ and $\mathrm{MR}^{\mathrm{lys} M c r e}$ mice using MOG on day 0 and twice injected with Pertussis; the clinical scores were record every day and illustrated on this graph; the experiment was independently repeated 3 times $(n=23-29)$.

\subsubsection{Relative expression levels of AAM markers in PMs from EAE mice}

At the end of EAE experiments I sacrificed the mice and isolated their P.Ms. Gene expression in these cells was compared by qPCR. Here I compared the gene expression of AAM markers in PMs between both genotypes. The $M R^{\text {lysMcre }} P M s$ expressed significantly more AAM markers compared to the $M R^{\text {flox/flox }} P M s$, which was not observed in PMs from healthy mice of both genotypes (Figure 11). 


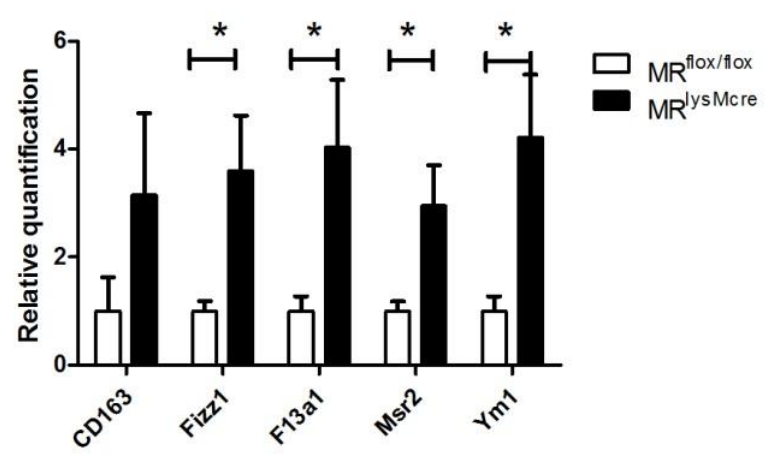

Figure 11: Relative gene expression in PMs from EAE mice. The PMs were elicited from peritoneal cavity of EAE mice $92 \mathrm{~h}$ after thioglycolate injection; RNA was isolated from the cells and reverse transcript to cDNA; relative expression levels of AAM markers mRNA were obtained by normalizing to HPRT mRNA expression; relative expression in cells from MR $^{\text {flox/lox }}$ mice was set equal to 1 ; mean + s.e.m. $(n=16-18)$. The relative expression levels of anti-inflammatory genes in $\mathrm{MR}^{\text {lysMcre }}$ macrophages were compared to that in $\mathrm{MR}^{\text {flox/flox }}$ macrophages.

\subsubsection{Relative expression levels of AAM markers in spinal cord infiltrating cells from EAE mice}

At the end of EAE experiments we sacrificed the mice and isolated the infiltrating cells from their spinal cords. Gene expression in these cells was compared by qPCR. Since Arginase1 and iNOS are two competitors in producing NO in macrophage, their gene expressions were compared (Figure 12C). The two genotypes showed completely different expression pattern. In the cells from MRlysMcre mice expression of Arginase1 was significantly higher than in those from MRflox/flox mice, while the pattern of iNOS expression was inverted. This observation may reflect a strongly reduced NO production in MRlysMcre mice during the chronic phase of EAE. I also compared gene expression of the AAM markers (Figure 12A). Because of the almost unique expression of these markers in 
macrophages, their expression in the infiltrating cells could reflect the polarization of macrophages. The cells from MRlysMcre mice expressed these genes slightly more than those from MRflox/flox mice. Meanwhile, the gene expression of proinflammatory cytokines was simimlar between both genotypes (Figure 12B).

A

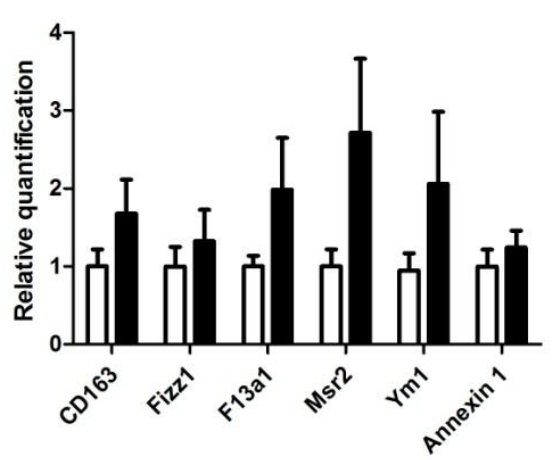

C

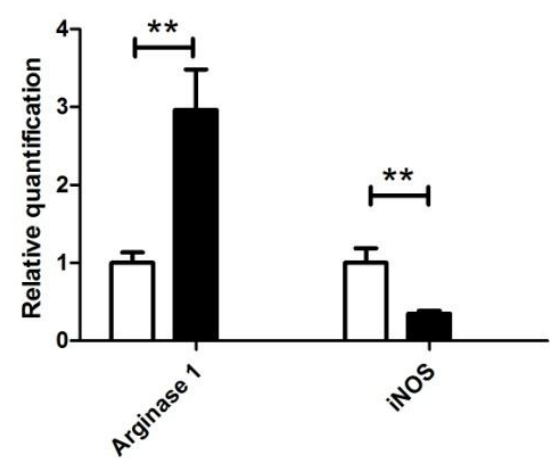

B

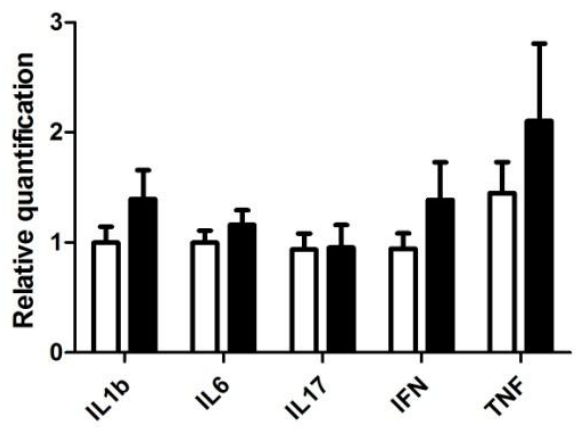

Figure 12: Relative gene expression levels in spinal cord infiltrating cells from EAE mice.

The spinal cord infiltrating cells were isolated from EAE mice by percoll gradient; RNA was isolated from the cells and reverse transcript to cDNA; relative expression levels of AAM markers mRNA were obtained by normalizing to HPRT mRNA expression; relative expression in cells from MR ${ }^{\text {flox/llox }}$ mice was set equal to 1 ; mean + s.e.m. $(n=16-18)$. The relative expression levels of anti-inflammatory genes $(A)$ and pro-inflammatory genes $(B)$ in $M R^{\text {lysMcre }}$ macrophages are compared to that in $\mathrm{MR}^{\text {flox/flox }}$ macrophages. To highlight the difference between the two genotypes, the relative expression levels of Arginase 1 and iNOS are depictured together (C). 


\subsubsection{Histological analysis of EAE mice}

Next, I investigated whether the amelioration of EAE correlated with improved histopathologic features. In $\mathrm{MR}^{\mathrm{lys} M c r e}$ mice, the macrophage infiltration in total spinal cord and white matter (Figure 13A left and right) was significantly reduced compared with that in $\mathrm{MR}^{\text {floxflox }}$ mice, whereas the $T$ lymphocytes infiltration in total spinal cord and white matter (Figure 13B left and right) was not altered in both genotypes.

A striking accordance to the clinical scoring data, the myelin sheath in $M^{\text {floxflox }}$ mice was more dramatically damaged and more litter debris around lesion sites than those in $\mathrm{MR}^{\mathrm{lys} M c r e}$ mice (Figure 13C). 


\section{Results}

A
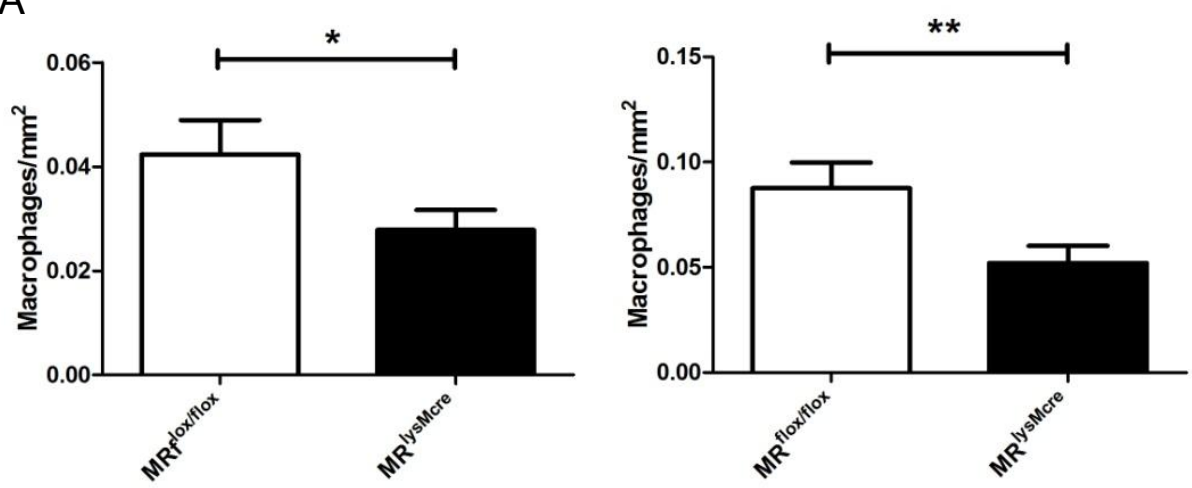

B
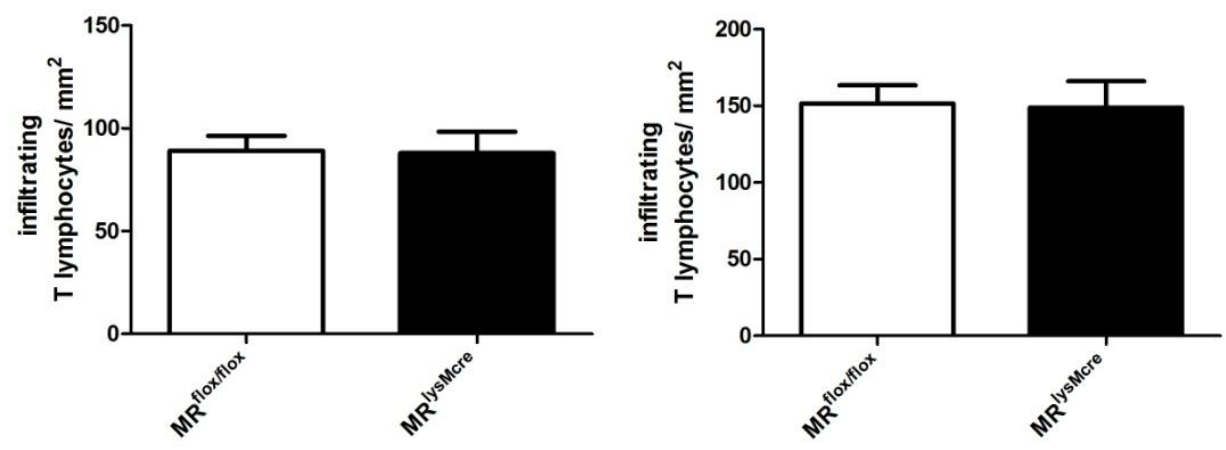

C

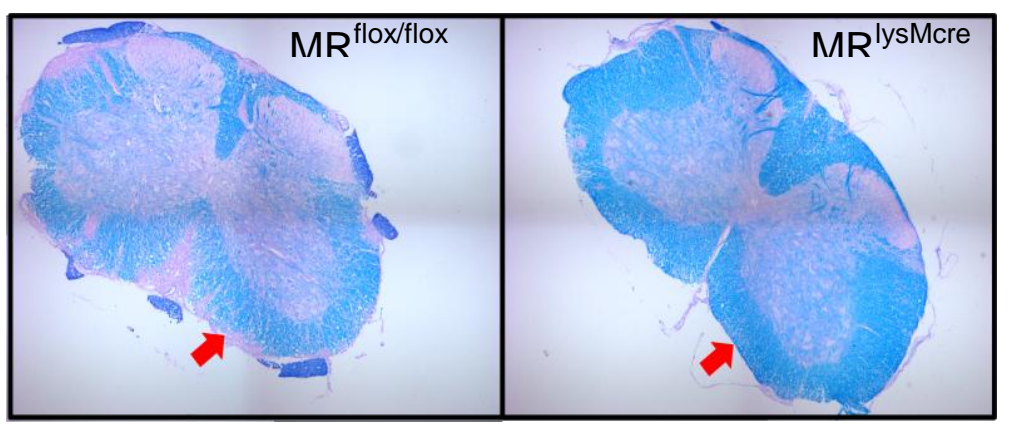

Figure 13: Histological analysis of spinal cord from EAE mice. A) The infiltrating macrophages in total spinal cord (left) and white matter (right) were stained with Mac3 antibody and determined as macrophages $/ \mathrm{mm}^{2}$ on ImageJ; this ratio was then depictured; B) the infiltrating T lymphocytes in total spinal cord (left) and white matter (right) were staind with anti-CD3 antibody and determined as T lymphocytes $/ \mathrm{mm}^{2}$ on ImageJ; this ratio was then depictured; C) The myeline sheath was stained with a blue myelin stain (luxol fast blue); the damage of myeline was compared under microscope. 


\subsection{Generation of inducible and reversible knockdown mouse models}

\subsubsection{Simplifying the cloning procedure}

Cloning of the shRNA sequence is the first important step necessary for using the inducible and reversible gene knockdown system. The basic principle of the previous protocol was as follows: The oligos containing the shRNA sequence are annealed, phosphorylated and cloned into the Bbsl and $\mathrm{Xhol}$ sites of $\mathrm{pH} 1$ tet-flex; in this vector the fragment spanning from the H1tet-Promoter to the end of the shRNA sequence is amplified and extended by a Pacl tag on both ends using mutagenic primers; after digesting, the PCR fragment can be cloned into the FUTG vector, in which the second cassette of the system was already placed; however the last step is practically difficult to perform and a bypass through the vector pBluesript was mostly required. The whole cloning protocol takes a long time and the difficult cloning steps always used to be repeated for the cloning of each shRNA sequence. Since the new system is interested to be a common method for making a gene knockdown it was necessary to simplify the cloning protocol. The underlying principle was to generate a vector in which the H1tet-promoter and the second cassette were already placed by leaving cloning sites for the shRNA, so that later after annealing and phosphorylating any other shRNA sequence can be cloned in one step into the final vector (Figure 14A, B).

In order to archive the goal I first modified the Bbsl site to Agel, because the $\mathrm{Bbsl}$ of the old cloning sites was not unique in the final vector (Figure 14A, C1-2). After replacement of the old $\mathrm{H} 1$ tet-promoter with the modified one I cut the fragment spanning from Sall to Xhol out and cloned it into the FUTG vector via the Xhol site using the compatible ends of Xhol and Sall. 
The Xhol and Agel were now unique in the new vector, named FH1UTG-Agel new and ready for further shRNA cloning (Figure 14B). Because of the abnormal recognition site of Bbsl the last six bases in the H1tet-promoter would have been removed during cloning, which does no longer occur after modifying it from Bbsl to Agel. Hence I removed the last six bases by mutagenic PCR, without altering the transcription activity of the promoter (Figure 14C2-3). By completing this step the new one step cloning vector "FH1UTG-Agel new" was successfully generated. 


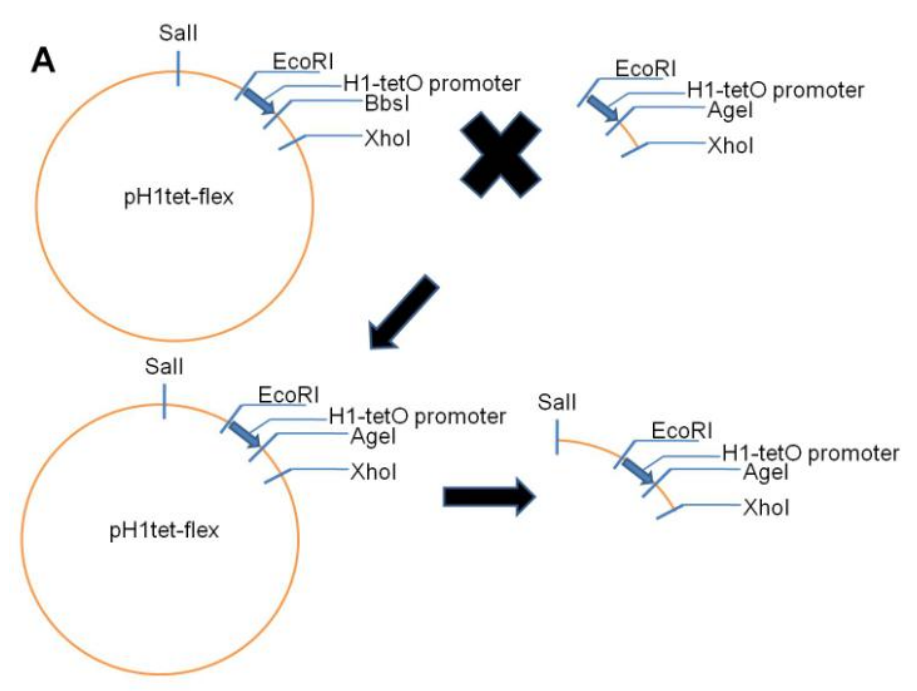

B Sall

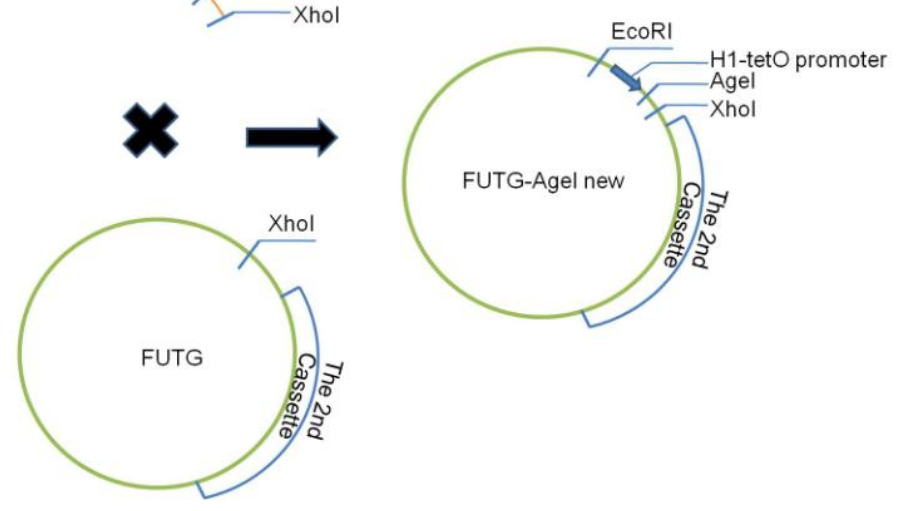

C

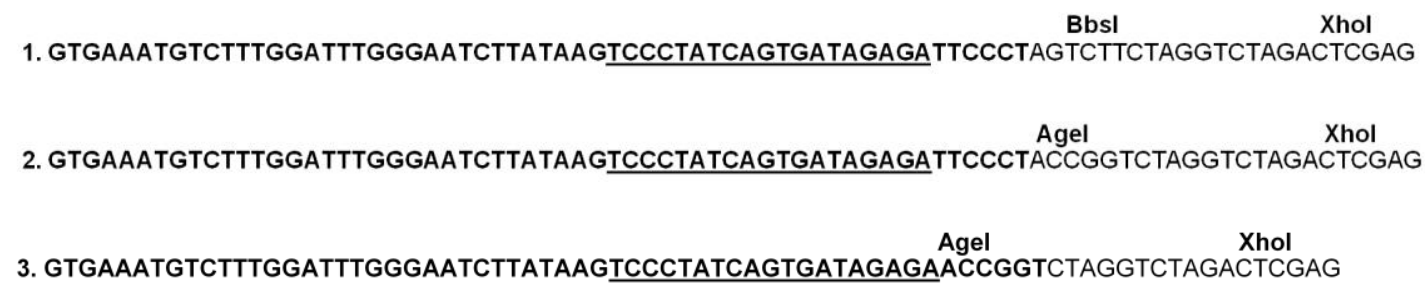

Figure 14: Schema of the cloning strategy. A) The cloning sites for the shRNA were mutated from Bbsl-Xhol to Agel-Xhol; the segment between Sall and Xhol was cut out for next step; B) The segment from the vector pH1tet-flex was cloned into the vector FUTG at the Xhol site, upstream of the second cassette of the inducible and reversible gene knockdown system. The new vector was called "FUTG-Agel new"; C) All sequences represent the sequences of the H1tet-promoter and the shRNA cloning sites; the bases in boldface represent the whole H1tet-promoter region, and the underlined bases represent the tet-repressor region; the first sequence is the original sequence; the 
second sequence is the sequence after transforming from the Bbsl recognition sequence to the Agel recognition sequence; the third sequence represents the sequence after modifying the H1 tet-promoter region.

\subsubsection{Cloning of shMR, shGR and shSirt1 sequences}

I cloned one shGR sequence, five shMR sequences and four shSirt1 sequences (see Material 2.6.3) into the "FH1UTG-Agel new". As shown in Figure 14B, I left the Agel and Xhol sites for shRNA cloning. After cloning the fragment between EcoRI and Xhol was around 60bp, which represents the length of shRNA sequence, longer than the fragment before the cloning. This 60 bp difference could be directly observed on a $1 \%$ agarose gel (Figure 15).

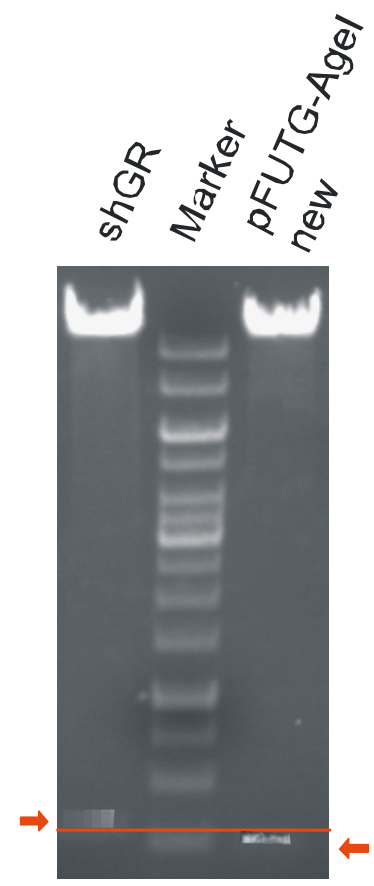

Figure 15: Verifying the plasmids containing the cloned shRNAs. The colonies on the selection plate were expanded in selection LB medium; the plasmids were isolated and digested by EocRI and Xhol, then loaded on $1 \%$ agarose gel. The segment cut from the plasmid containing the shRNA (here shGR is given as an example) was compared to the one from the empty plasmid, the right and the left arrow, respectively. 


\subsubsection{Titration of lentivirus with shRNA}

For successful virus injection into zygotes, we need highly concentrated viruspreparation $\left(10^{7}-10^{8} \mathrm{TU} / \mathrm{mL}\right)$. After ultra centrifugation I identified the viral concentrate by titrated infection of HEK293 cells. After 48h I identified the infected cells on the basis of EGFP expression by FACS. The percentage of GFP positive cells in relationship to the volume of virus (after 1:100 dilution) is depictured (Figure 16A). The curve in the smaller volumes region (1-10 $\mu \mathrm{L})$ revealed a lineage relationship between GFP positive cells and the volume of virus which means in range of these volumes almost each target cell had been infected by a unique lentivirus (Figure 16B). Depicting this region in a new graph, I calculated the $\mathrm{TU} / \mathrm{mL}$ using the trend line to be around $3^{*} 10^{7} \mathrm{TU} / \mathrm{mL}$, which corresponds to the lower range of sufficient viral concentration for zygote injection.

A

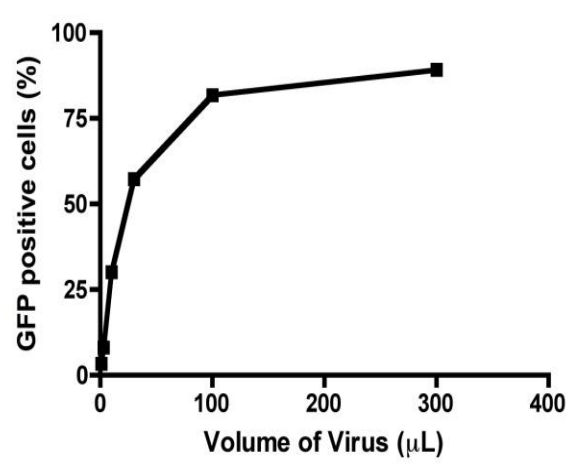

B

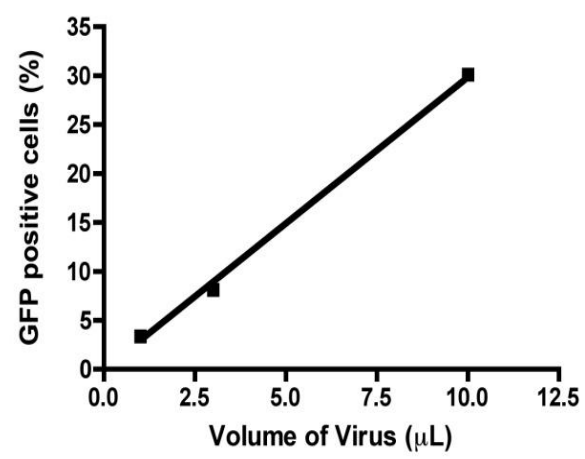

Figure 16: Titration of a lentivirus containing a shGR. The "Volume of Virus" refers to the volume of the 1:100 dilution of virus concentrate; the tested volumes included $1 \mu \mathrm{L}, 3 \mu \mathrm{L}, 10 \mu \mathrm{L}, 30 \mu \mathrm{L}$, $100 \mu \mathrm{L}$ and $300 \mu \mathrm{L}$; the virus was incubated with HEK293 cells for 2 days; the infected HEK293 cells were determined by flow cytometry; A) values were connected by a smooth curve; B) the regression curve of the first three values represents the "linear region", in which the percentage of infected cells corresponded to the virus volume. 


\subsection{4 shRNA functional test in vitro}

To identify the knockdown efficiency of the shGR in the new lentiviral construct, I infected MEF cells with the lentiviruses. Then I treated the cells with $2 \mathrm{ug} / \mathrm{mL}$ Doxycycline for 3 days to induce the shGR expression, and equal amount PBS as control. Before harvesting the cells I identified the infected cell population by EGFP expression (Figure 17A). The FACS data showed over $90 \%$ of infected cells, which excluded the possibility that a low protein knockdown efficiency was caused by a low infection rate. Then I identified the GR knockdown by western blot (Figure 17B). After Doxycycline treatment the GR had almost disappeared in contrast to PBS treatment, indicating that the shGR in the new plasmid allowed efficient knockdown of the GR. 
A

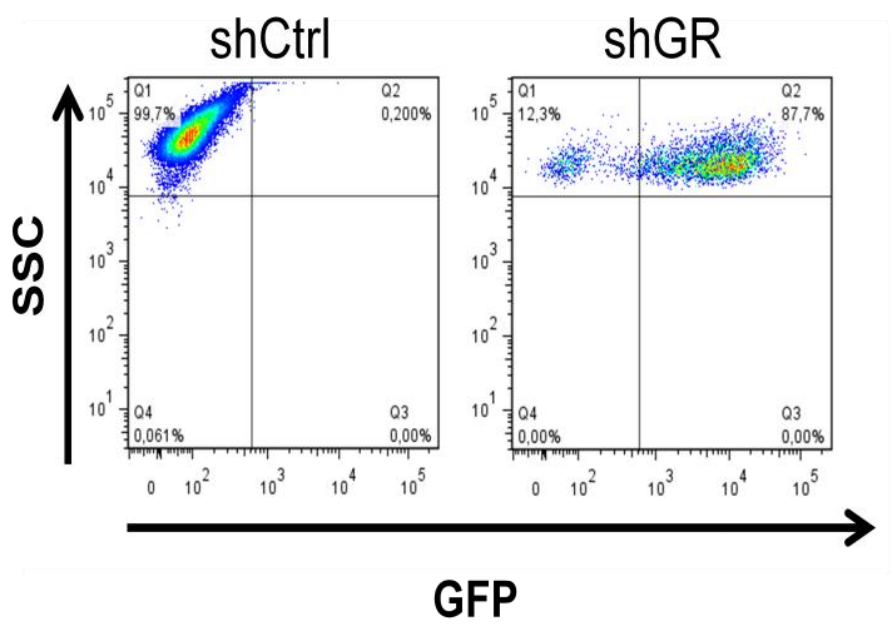

B

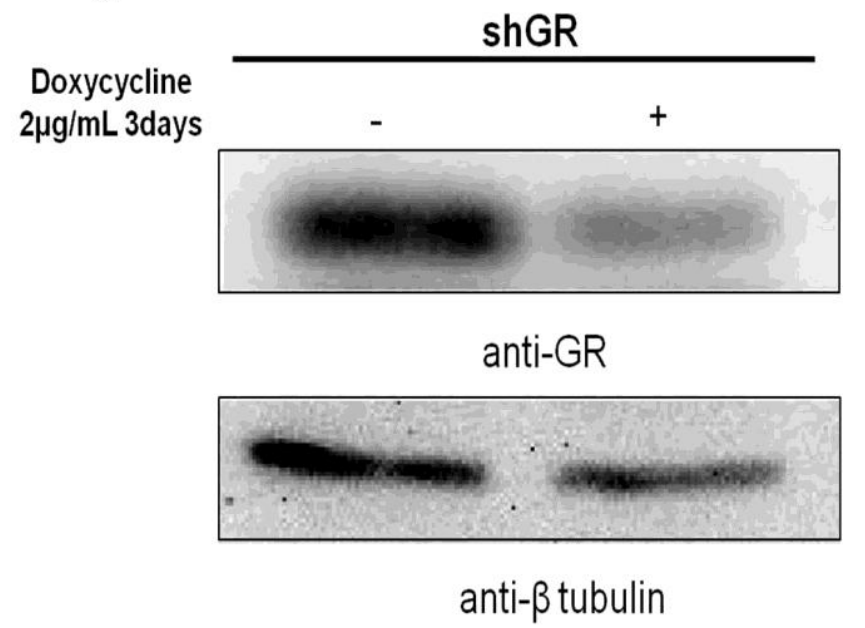

Figure 17: Test of the inducible knockdown using the shGR lentivirus in MEF cells. The shGR transfected MEFs were cultured with $2 \mathrm{ug} / \mathrm{mL}$ Doxycycline (+) or an equal amount of PBS (-) as a control, for 3 days; from the cultures some cells were directly used to identify the percentage of positive transfecet cells by flow cytometry and compared to non-infected cells $(A)$, the lysates from the rest of the cells were loaded on a SDS-PAGE gel for western blot; an anti- $\beta$ tubulin antibody was used as loading control (B).

In case of the shMR, we have neither a verified shMR sequence nor mouse MR expressing cell line in culture. So I first generated the mouse MR overexpressing cells by transfecting the mouse MR cDNA via the pCDNA vector by using $\mathrm{Ca}_{3}\left(\mathrm{PO}_{4}\right)_{2}$ precipitation. After several weeks, I chose the clone that expressed MR most efficiently and compared with the 
kidney lysate from mice (Figure 18A) by western blot, and the lysate from leber was used as a negative control. The western blot showed the MR band from HEK293 cells at a similar position compared with the endogenous MR in kidney.

After accomplishing the MR overexpressing cells, I cloned five different sequences into the new plasmid and generated lentiviruses, then infected HEK293 MR overexpressing cells. I treated the cells with $2 \mathrm{ug} / \mathrm{mL}$ Doxycycline for 3 days to induce the shRNA expression, and equal amount PBS as a control. Before harvesting the cells I identified the infected cells by EGFP expression (Figure 18B). The FACS data showed the cell populations for each shMR sequence were almost equally infected, which excluded the possibility of low protein knockdown efficiency caused by a low infection rate. Then I identified MR knockdown efficiency of those candidates by western blot (Figure 18C). After Doxycycline treatment the $4^{\text {th }}$ shMR sequence demonstrated the most reliable MR knockdown efficiency compared to the other sequences. 
A

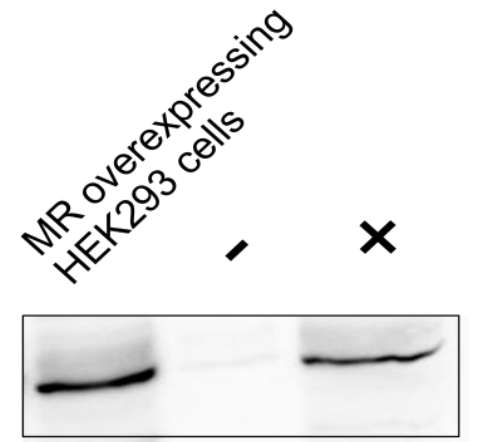

anti-MR

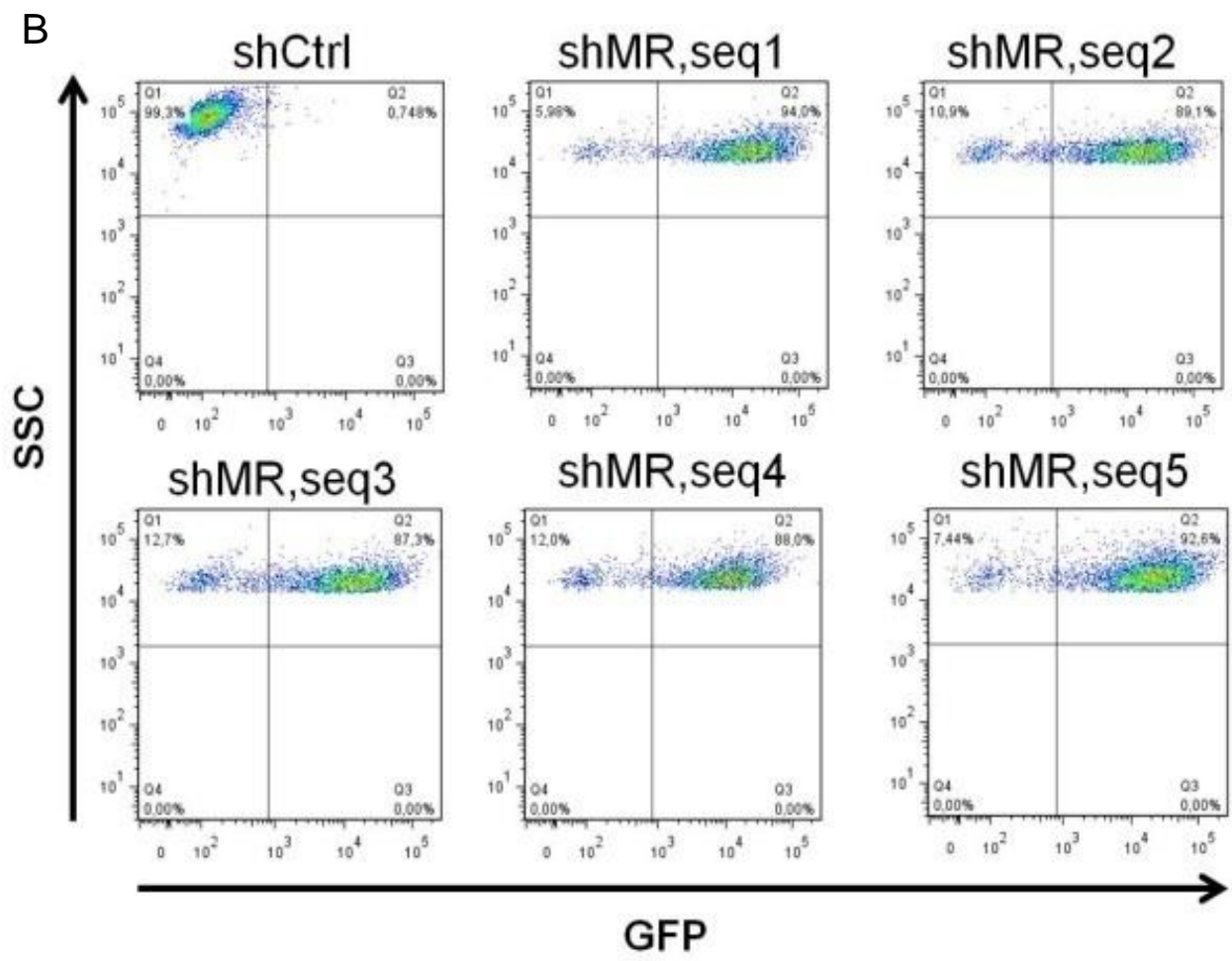

C ShMR

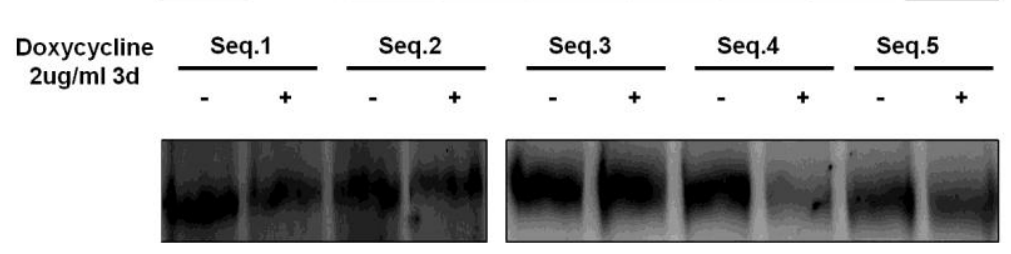

anti-MR
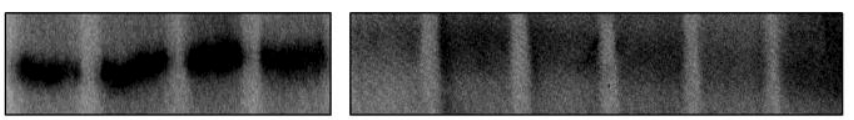

anti- $\beta$ tubulin

Figure 18: Test of the inducible knockdown using five shMR sequences in MR 
overexpressing HEK293 cells. A) the MR overexpressing HEK293 cells were generated by transfecting mouse MR cDNA via pCDNA3 vector; after clone selection, the cell lysate was compared with the positive control (+), kidney lysate from mice, and the negative control (-), leber lysate from mice; B) The percentage of infected cells were quantified by flow cytometry and compared to non-infected cells; C) The shMR transfected cells were cultured with $2 \mathrm{ug} / \mathrm{mL}$ Doxycycline (+) or an equal amount of PBS (-) as a control, for 3 days; the lysates from the rest of cells were loaded on a SDS-PAGE gel for western blot; analysis the blot was incubated with anti- $\beta$ tubulin as a loading control.

As in the case of shMR, we did not have a verified shSirt1 sequence. So I first cloned four different sequences into the new plasmid and generated lentivirus, then infected $\mathrm{C} 2 \mathrm{C} 12$ cells. I treated the cells with $2 \mu \mathrm{g} / \mathrm{mL}$ Doxycycline for 3 days to induce the shRNA expression or an equal amount of PBS as a control. Before harvesting the cells I identified the infected cells by EGFP expression (Figure 19A). The FACS data showed thath the cell populations for each shSirt1 sequence were almost equally infected, which excluded the possibility of low protein knockdown efficiency caused by a low infection rate. Then I identified the Sirt1 knockdown efficiency of those candidates by western blot (Figure 19B). After Doxycycline treatment the $3^{\text {rd }}$ shSirt1 sequence leads to the stronger Sirt1 knockdown efficiency compared to the other sequences. 
A

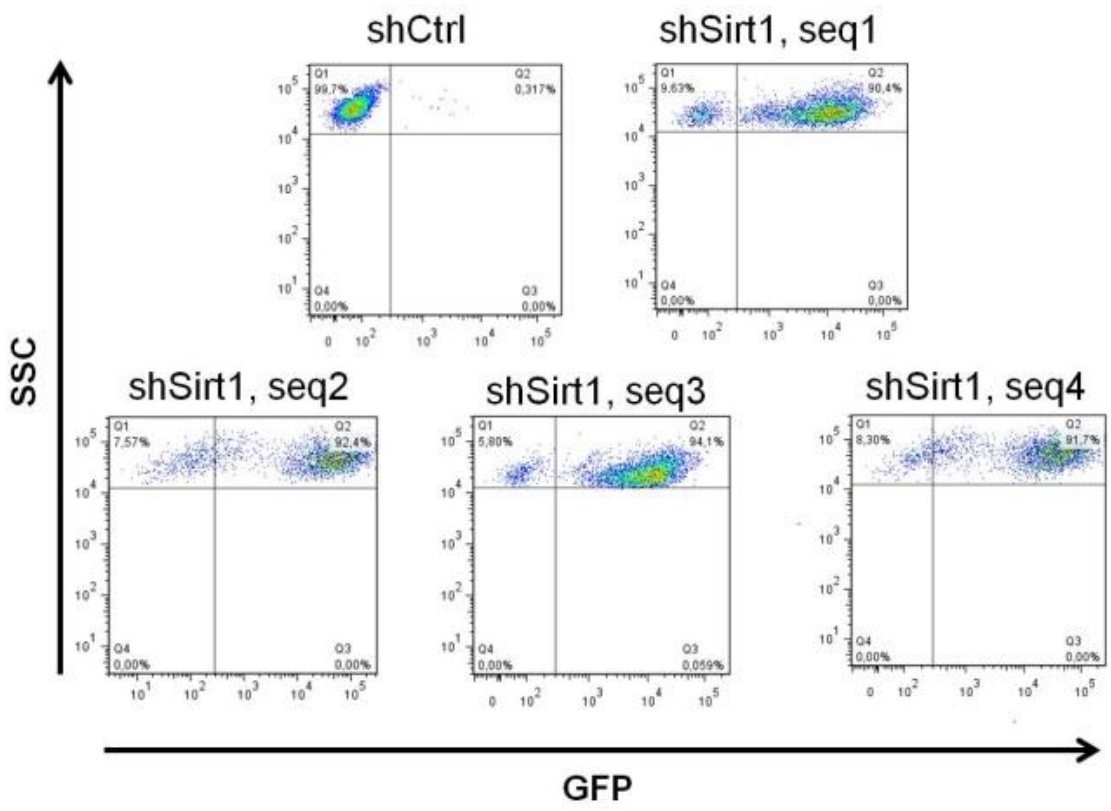

B

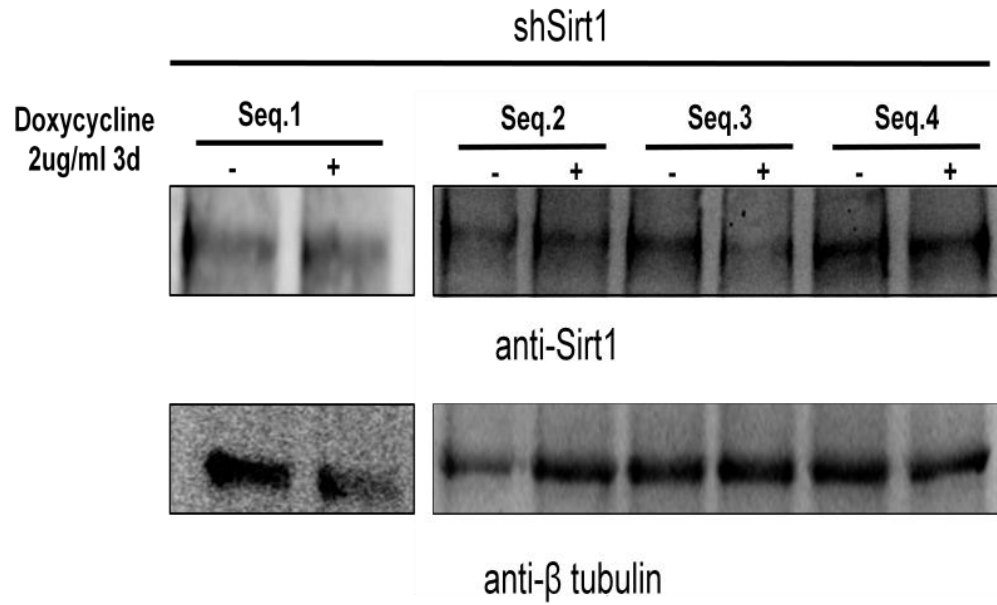

Figure 19: Test of the inducible knockdown using four shSirt1 sequences in $\mathrm{C} 2 \mathrm{C} 12$ cells. A)

The percentage of infected cells was quantified by flow cytometry and compared to non-infected cells; B) The shSirt1 tranfected cells were cultured with $2 \mathrm{ug} / \mathrm{mL}$ Doxycycline (+) or an equal amount of PBS (-) as a control, for 3 days; the lysates from the rest of cells were loaded on a SDS-PAGE gel for western blot; analysis the blot was incubated with anti- $\beta$ tubulin as loading control. 


\subsubsection{Functional test of the shGR knockdown}

In order to functionally verify the knockdown of the GR, I investigated the GR target gene expression. Due to further treatment on the cells, I did the first test to exclude the effects of the further treatment on GR knockdown (Figure 20). After addition of Doxycycline the shGR was highly efficient in reducing GR mRNA levels compared to PBS, and independently of the treatment with Dex, PMA or both. MEF gr-/- cells were used as a positive control.

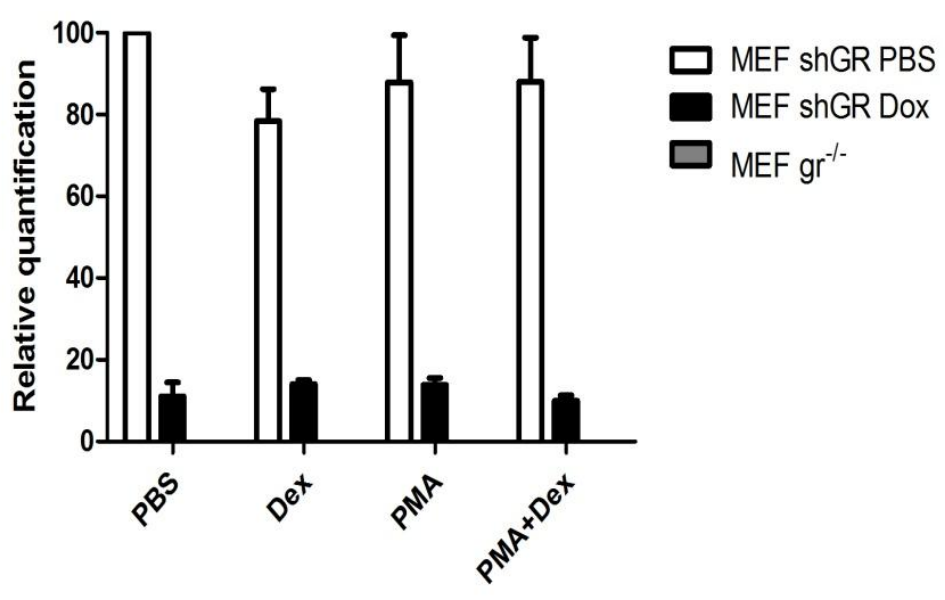

Figure 20: Test of the GR knockdown efficiency achieved by using the shGR lentivirus. The shGR transfected MEF cells were incubated with Dox $(2 \mu \mathrm{g} / \mathrm{mL})$ or an equal amount of PBS for 3 days; MEF $\mathrm{gr}^{-/-}$cells were used as control; cells were additionally treated with either $\operatorname{Dex}\left(10^{-7} \mathrm{M}\right)$ or PMA, or both; RNA was isolated from cells and reverse transcript to cDNA; relative expression level of GR mRNA was obtained by normalizing to HPRT mRNA; mean + s.e.m. $(n=4)$.

I chose two genes, GILZ and IL6, to test the physiological function of the GR knockdown, because they were regulated by GR in opposing directions. GILZ expression is upregulated by GR activation. After administration of GC derivate Dex, only in MEFs with shGR and PBS, GILZ expression was elevated, while in MEFs with shGR and Dox, GILZ expression maintained almost unaltered as in the MEF $\mathrm{gr}^{-/}$cells (Figure 21 
A). IL6 expression is downregulated by GR activation and upregulated by protein kinase $\mathrm{C}(\mathrm{PKC})$. So I induced IL6 expression with PMA, an activator of PKC. PMA treatment enhanced slightly in all three cell groups the IL6 expression (Figure 21B). After addition of Dex, only in MEFs with shGR and PBS, IL6 expression was robustly reduced, whereas it maintained in the other two groups, MEFs with shGR and Dox and MEF $\mathrm{gr}^{-1 /}$.
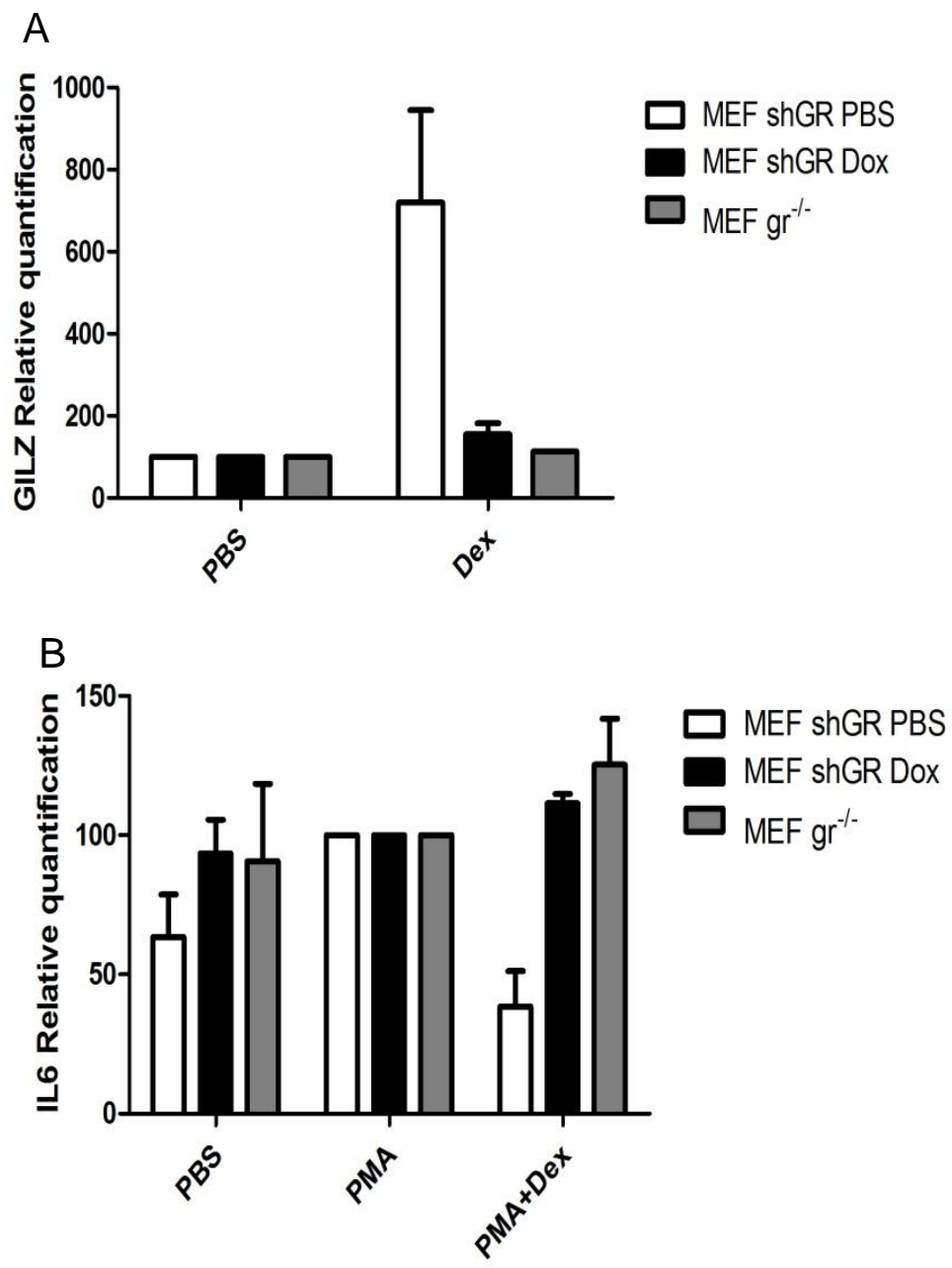

Figure 21: Functional tests of GR knockdown efficiency by using shGR lentivirus. The shGR transfected MEF cells were incubated with Dox $(2 \mu \mathrm{g} / \mathrm{mL})$ or an equal amount of PBS for 3 days; MEF $\mathrm{gr}^{-/}$cells were used as a control; A) cells were additionally treated with Dex $\left(10^{-7} \mathrm{M}\right)$ or equal amount PBS; B) cells were additionally treated with either PMA or PMA + Dex $\left(10^{-7} \mathrm{M}\right)$, or an equal amount of PBS; RNA was isolated from cells and revers transcript to CDNA; relative expression levels of GILZ and IL6 mRNA were obtained by normalizing to HPRT mRNA; mean + s.e.m. ( $n=5)$. 


\subsubsection{Test of transgenic mice}

The virus was injected into two-cell stage embryos and transferred into the oviduct of peseudopregnant female mice. From these femals we got 8 offsprings. We took tail blood from the offsprings and identified the EGFP expression (Figure 22A). We got four candidates having high EGFP expression level in cells. The cells from mouse 2, 5, 8 showed obvious high percentage of EGFP positive cells, over $90 \%$, suggesting that in these mice the integration of shMR containing lentiviral vector was successful and well distributed during the individuall growth. 
A
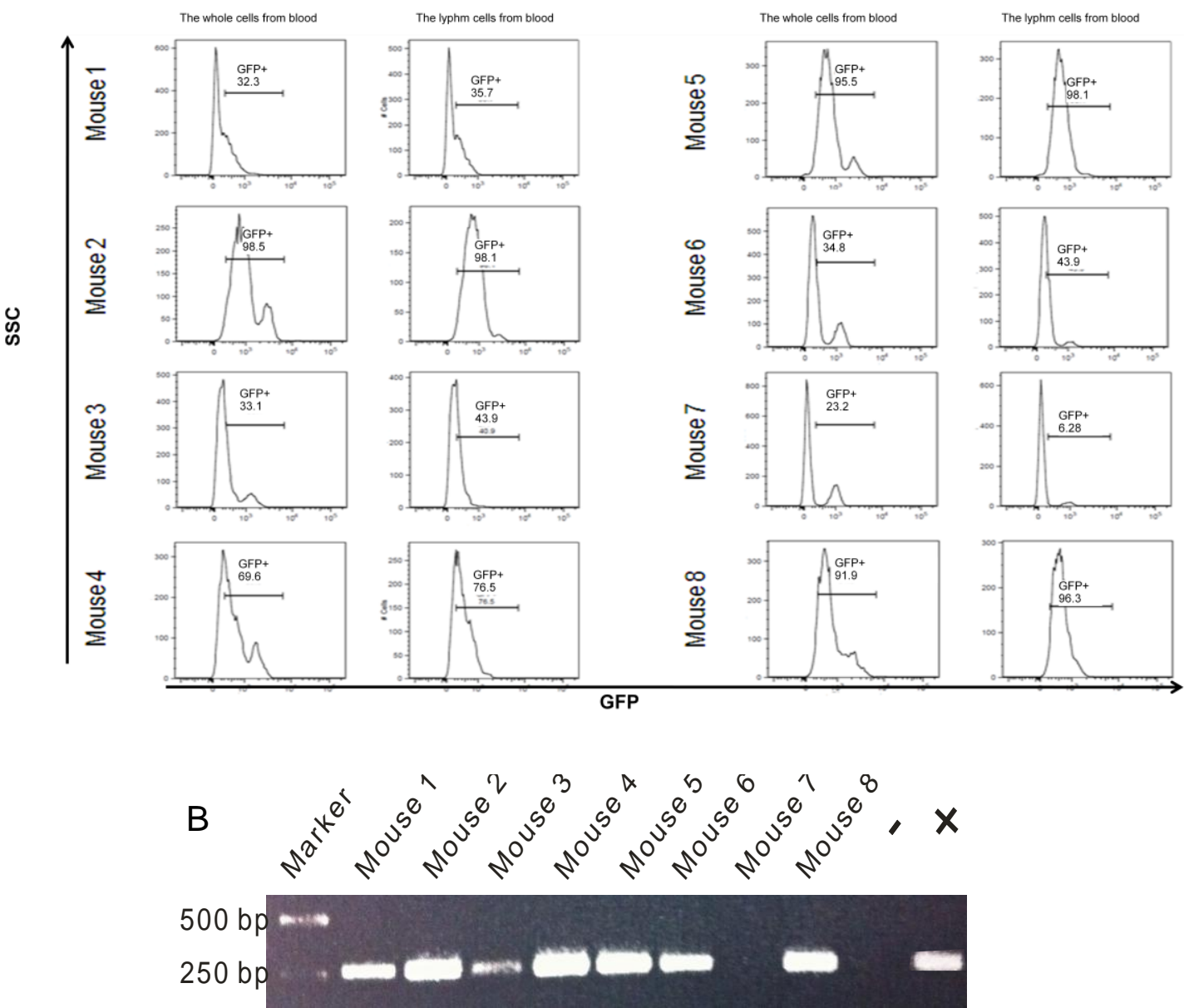

Figure 22: Test of transgene integration in offspring from transgenic mice. A) The blood from tails of 3 weeks old mice was collected; either the whole blood cells or pure lymph cell population were measured by flow cytometry and gated for EGFP positive cells; B) RNA was isolated from the rest of the blood cells and reverse transcript to cDNA; the successful integration of the lentiviral construct was determined on agarose gel after PCR with primer pair "FUTG rettung"; the $1^{\text {st }}$ lane was loaded with fermentas $\AA^{\circledR} 1 \mathrm{~kb}$ DNA ladder, the $2^{\text {nd }}$ to $9^{\text {th }}$ lanes were loaded with PCR samples of mouse 1 to 8 , correspondingly, the $10^{\text {th }}$ lane was loaded with PCR sample of water, as a negative control (-), the $11^{\text {th }}$ lane was loaded with PCR sample of the lentiviral construct, as a positive control (+).

To further verify the successful integration of the lentiviral construct, we isolated the RNA from the rest of the blood cells and reverse transcript to cDNA. Then, I performed PCR with primer pair "FUTG rettung": (forward) 5'-GCGTTCGAATTCCATGGGTCGAGTTAATTA-3' and (reverse) 5'-ATTA ACTCGAGTCTAGACCTAGACCGGTTCTCTATCACTGATAGGGACTTAT AAGATTCC-3' (Figure 22B). Although the primer pair was previously designed for modifying the last six bases in $\mathrm{H} 1$ promoter, after shRNA 
cloning the last over $30 \mathrm{bp}$ in the reverse primer are still complementary to the sequence in our lentiviral construct. The amplified bands revealed the successful integration of lentiviral construct in the offsprings, and in some degree their intensity corresponded to the EGFP positive cell population showed in our FACS data. 


\section{Discussion}

\subsection{Effect of myeloid cell-specific ablation of MR on macrophages polarization}

Macrophages play an essential role in innate and adaptive immune defense. Recently, the functional heterogeneity of macrophages attracted many focus because of its importance in homeostasis in immune responses and the chronic inflammatory diseases as consequence of the homeostasis disorder. Analogous to the Th1 and Th2 dichotomy of T cell polarization, macrophages can be polarized by the microenvironment to mount specific M1 or M2 functional programs (Gordon, 2003). Classic or M1 macrophage activation in response to microbial products or IFN- $\gamma$ is characterized by high capacity to present antigen; high IL-12 and IL-23 production and consequent activation of a polarized type I response; and high production of nitric oxide (NO) and reactive oxygen intermediates. Thus, M1 macrophages are generally considered potent effector cells that kill intracellular micro-organisms and tumor cells and produce copious amounts of proinflammatory cytokines. In contrast, alternative activation of macrophages is promoted by various signals, such as IL-4, IL-13, GCs, IL-10, Ig complexes/Toll-like receptor (TLR) ligands that elicit different M2 forms, able to tune inflammatory responses and adaptive Th2 immunity, scavenge debris, and promote angiogenesis, tissue remodeling, and repair (Mantovani et al., 2002).

The activated PPARy can also polarize macrophages towards alternatively activated state and partially overlaps that activated by GR (Caglayan et al., 2008). On the other hand, the effect of MR antagonists in mitigating cardiac and vascular inflammation and fibrosis was found to be similar to 
that of activation of PPARy by pioglitazone (Usher et al., 2010; Blasi et al., 2003). To address the effect that a myeloid cell-specific MR knockout has on macrophage polarization, I compared the AAM characteristics between both genotypes. In both BMDMs and PMs, the AAM markers expression (Mantovani et al., 2004) by MR ${ }^{\text {lysMcre }}$ macrophages was even or equal to that by $\mathrm{MR}^{\text {floxflox }}$ macrophages. The production of NO, which is respond for oxidative stress and tissue damage (Farias et al., 2007; Aboul-Enein et al., 2006) was only potentially reduced, according to the significantly less iNOS expression by $M^{\text {lysMcre }} B M D M s$ than that by $M^{\text {flox/flox }}$ BMDMs. The nearly undistinguishable markers expression pattern in BMDMs between both genotypes was also observed by the other group (Frieler et al., 2011) and can be a consequent of that all the BMDMs were freshly derived from bone marrow myeloid cells in cell culture, thereby in an inactivated status. However, the iNOS expression was different in BMDMs between both genotypes. A possible explanation could be that the iNOS can be more directly regulated by MR (Takeda, 2004) than the other inflammatory genes, thereby a minor level of GCs or MCs in the used medium can via MR elevate the iNOS expression. Additionally, low concentration of GC can also induce iNOS expression via GR in macrophages (Haigis et al., 2006). In case of PMs, they were elicited from healthy mice so that similar to those freshly derived BMDMs they did not exert difference in gene expression. GR signaling can elevate phagocytosis of apoptotic cells by macrophage (Lui et al., 1999), and MR and GR have largely opposing effect on macrophages (Lyons et al., 2007), thereby the possible MR signling activated by GCs in serum can reduce the phagocytotic activity of macrophage.The phagocytosis of apoptotic cells by macrophage is a much complicated process, which involves many cell surface molecules including lectins (Duvall et al., 1985), $\alpha_{v} \beta_{3}$ integrin/CD36/thrombospondin complex (Savill et al., 1990; Savill et al., 1992), phosphatidylserine receptors (Fadok et al., 2000), scavenger receptors (Platt et al., 1996), 
receptors for oxidized lipids (Chang et al., 1999), CD14 (Devitt et al., 1998), CD29 (Schwartz et al., 1999), the ABC1 transporter (Luciani et al., 1996), and receptors for complement components C3bi (CR3/CR4) (Mevorach et al., 1998) and C1q (Botto et al., 1998). To further determine how MR knockout enhances the phagocytotic capacity of macrophage, the expression of these molecules under MR knockout condition should be invetigated.

The difference between both genotypes appeared mainly after LPS stimulation. Regardless of addition of dexamethasone, MR ${ }^{\text {lysMcre }}$ BMDMs

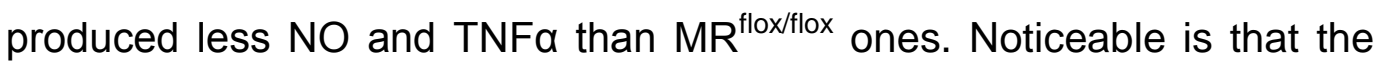
productions of NO and TNFa by MR ${ }^{\text {lysMcre }}$ BMDMs were strongly reduced as well as those by $\mathrm{MR}^{\text {floxflox }}$ BMDMs. Furthermore, the gene expression levels of Arginase 1 and iNOS differentiated towards two distinct directions in both genotypes. MR ${ }^{\text {lysMcre }}$ BMDMs expressed more Arginase1 and less iNOS than $M^{\text {floxfllox }}$ BMDMs did. Though the difference was not significant, combining the opposing directions could contributed to a strong decline of NO production, consisting with the observation of NO production. These imply that the less productions of $\mathrm{NO}$ and TNFa by MR ${ }^{\text {lysMcre }}$ BMDMs rather resulted from MR knockout than a GR- related anti-inflammatory effect, because as reported the activation of PPARY can inhibit toll-like receptor mediated activation of myeloid cells via MAP kinase and NF-KB pathways, by which the LPS induced the inflammatory response by macrophage (Silke et al., 2004), both activation of PPARY and MR antagonist mitigated inflammatory responses (Iglarz et al., 2003; Caglayan et al., 2008). This finding is consistent with the data of the other groups by using PPARy agonist (Ogawa et al., 2005). Their data show that in the PPARY agonist treated cells the iNOS expression after LPS stimulation was strongly reduced compared with non treated cells.

From the EAE mice, a stronger AAM polarization of $M^{\text {lysMcre }}$ mice than that in $\mathrm{MR}^{\text {floxflox }}$ mice was observed. However, this phenomenon could be 
different to that observed in LPS stimulation. The above discussed data obtained from in vitro without source of massive GCs. In EAE model, the mice were treated several times with injections (1x Subcutaneous with Mog and CFA, 2x Pertusis) and suffered from the disease. These physiological stresses can promote the GC expression in the mice and elevate the GC concentration in serum, to which that the GRs in macrophage can be more activated than that under normal physiological conditions. Hence, in MR ${ }^{\text {lysMcre }}$ macrohages due to lack of opposing effect by MR signaling, the activated $\mathrm{GR}$ can skew macrophages more preferentially to AAMs compared with in $\mathrm{MR}^{\text {floxflox }}$ macrohages. This may explain why the macrophages, both PMs and infiltrating cells from $M^{\text {lysMcre }}$ EAE mice exert the similar AAM markers expression pattern compared with the GC induced AAM (Mantovani et al., 2002).

From these data I conclude here that MR knockout can impact on macrophage polarization by exhibiting anti-inflammatory responses, particularly after pathogenic stimulation, but the cell characteristics are different from IL-4 or GC polarized AAMs.

\subsection{EAE development}

Despite extensive studies on MS patients and experimental research on animal models, the mechanisms underlying the physiopathology of MS remain only partially identified. However, the observation from relapsing-remitting MS suggests the presence of potent counter-regulatory mechanisms (Lassmann et al., 2007; Muzio et al., 2007).

The growing evidence of macrophage functional heterogeneity in different pathologies raises questions of their role in inflammatory or anti-inflammatory reactions during MS. It has been demonstrated that the AAMs are the key regulator factor in inflammatory diseases, such as 
inflammatory cerebral ischemia (Frieler et al., 2011) and renal disease (Wang et al., 2007). Additionally, it has also been shown that the myeloid cell-specific MR knockout can potentially skew macrophage polarization towards AAM (Usher et al., 2010; Frieler et al., 2011). In light of these results, the effect of myeloid cell-specific MR knockout on EAE attracted our focus.

In this project I performed the EAE in C57 BL/6 mice of two genotypes $M R^{\text {lysMcre }}$ and $M^{\text {floxfllox }}$. From three independent experiments I observed that $\mathrm{MR}^{\text {lysMcre }}$ mice suffered significantly less from the EAE compared with $M R^{\text {floxflox }}$ mice, especially, in the chronic phase. The histological images of lesion sites in spinal cord consistent with the observation of the severtity of $E A E:$ in $M^{\text {lysMcre }}$ mice, the myelin sheet was more intact than that in $M R^{\text {floxfllox }}$ mice. Because the $M R^{\text {lysMcre }}$ mice differ from the $M R^{\text {floxflox }}$ mice only in the absence of MR in myeloid cells, particularly in macrophages, thereby suggesting that myeloid cell-specific MR knockout reduce the severity of $\mathrm{EAE}$ in genotype $\mathrm{MR}^{\text {lysMcre }} \mathrm{C} 57 \mathrm{BL} / 6$ mice significantly compared with that in genotype $\mathrm{MR}^{\text {floxflox }}$.

How does myeloid cell-specific MR knockout reduce the EAE severity in vivo? The possible explanation is provided by the comparison of gene expression in PMs and spinal cord infiltrating cells from both genotypes EAE mice. In both PMs and spinal cord infiltrating cells from MR ${ }^{\text {lysMcre }} E A E$ mice, I detected an increase in expression of AAM markers genes, which are widely used to determine macrophage polarization (Mantovani et al., 2004), compared with that in those cells from $M^{\text {floxflox }}$ EAE mice. Particularly, I observed an increase in the expression of Arginase1 and a reduction in the expression of iNOS. Arginase1 and iNOS are competitive for L-arginine, which is converted into L-ornithine and urea (Wu and Morris, 1998) or citrulline and NO (Knowles and Moncada, 1994), by Arginase1 or iNOS, respectively. Thus, this opposing regulation of Arginase1 and iNOS can result in a reduction in NO secretion, which exerts deleterious effect in 
EAE and MS (Farias et al., 2007; Aboul-Enein et al., 2006). Accompanying with the reduction in the severity of EAE, the macrophage functional heterogeneity was also altered by MR knockout. These gene expression evidences suggest that in $\mathrm{MR}^{\text {lysMcre }}$ macrophages are more preferentially polarized to AAMs under EAE condition. However, I also observed that the other proinflammatory genes expression by spinal cord infiltrating cells was not altered by $\mathrm{MR}^{\text {lysMcre }}$. A possible explanation is that the spinal cord infiltrating cells include also other leukocytes, which participated in EAE pathology and also expressed those proinflammatory genes. On the other hand, our histological imaging of spinal cord infiltration showed that only macrophage infiltration was reduced in MR ${ }^{\text {lysMcre }}$ EAE mice compared with $M R^{\text {floxflox }}$ EAE mice, whereas the $T$ lymphocyte infiltration was not distinguishable. Hence, the expression of those proinflammatory could be contaminated by the other infiltrating leukocytes, which is not the case of AAM markers, because these AAM genes are more unique in macrophages (Mantovani et al., 2004).

Additionaly, the higher phagocytotic activity of the MR ${ }^{\text {lysMcre }}$ macrophages is also a possible factor that reduces the severity of EAE in the chronic phase. Since EAE involves many leukocytes in its pathology, even the $M^{\text {lysMcre }}$ macrophages are charaterised by anti-inflammatory profile, the myelin sheath and further axonal damage can still be caused by the other leukocyte, such as B cells and CD8+ T lymphocytes. Hence, a faster and more efficient regeneration of myelin and neuron is important by attenuating the disease severity. One essential factor for neuron regeneration is clearenc of debris around the lesion sites (Neumann et al., 2009). As the in vitro data showed, both MR knockout PMs and BMDMs have higher phagocytotic activity by clearance the apoptotic cells. It is tempting to assume that these $\mathrm{MR}^{\text {lysMcre }}$ macrophages are also more efficient by debris clearance than the $\mathrm{MR}^{\text {floxflox }}$. However, here we can not directly prove this assumption depending on our histological analysis of 
myelin staining. We can not exclude the possibility that the less damaged myelin was a consequence of the anti-inflammatory response elicited by $M^{\text {IysMcre }}$ macrophages.

Previous data from our group showed that in treatment with $100 \mathrm{mg}$ Dex on three consecutive days the $T$ lymphocytes are the major target of Dex treatment (Wüst et al., 2008), while the GR in macrophages is not essential for this treatment. This result was obtained from comparison within the two genotypes, $\mathrm{GR}^{\text {floxflox }}$ and $\mathrm{GR}^{\text {lysMcre }}$, with or without Dex application. In both genotypes, the severity of EAE was significantly attenuated after Dex application. However, the $\mathrm{GR}^{\text {floxflox }}$ mice were more accessible to Dex treatment than $\mathrm{GR}^{\text {lysMcre }}$ mice. In the following paper published by our group (Schweingruber et al., 2011), the difference after treatment between both genotypes was observed again by using liposome-encapsulated Dex. The overall efficacy of therapy in GR R $^{\text {lysMcre }}$ mice was reduced and accompanying with significantly higher NO production compared with $\mathrm{GR}^{\text {floxflox }}$ mice. After treatment, the macrophages exhibited significant AAM characteristic in gene expression pattern and less infiltrated in spinal cord, which are similar to the observations in this study. There are two conclusions I can draw from combining these previous data with my results. First, myeloid cell-specific MR knockout has similar effect on attenuating the severity of EAE compared with Dex application, especially through liposome. The two treatments are based on the same scenario: macrophages, in which the GR signaling is dominant to MR signaling, polarize preferentially towards AAMs. Because of the lack of $11 \beta \mathrm{HSDII}$ and much higher affinity of MR to GC than that of GR, MRs in macrophages bind constitutively with GCs even at lower GC concentration. Although the underlying mechanism is still unclear, from many studies that show MR inhibition or knockout can skew macrophage polarization towards AAM one can conjecture that MR signaling is suppressive for AAM characteristic. As counter player, GR 
activation requires a much higher local concentration to skew the polarization towards AAM (Mantovani et al., 2002). The application of Dex, especially via liposome, provides a local high concentration of Dex. In our case, disease caused stress can elevate the GC level in serum and additional with MR depletion, which help the GR signaling be dominant in macrophages. Hence, we observed the similar consequences after liposome-encapsulated Dex application compared with MR knockout.

The $M R^{\text {lysMcre }}$ mice benefited from these AAMs anti-inflammatory and wound healing effect. Histological analysis showed in $\mathrm{MR}^{\text {lysMcre }}$ mice the myelin sheath was significantly more intact than that in $\mathrm{MR}^{\text {floxflox }}$ mice in the chronic phase of EAE. However, we cannot determine whether in $\mathrm{MR}^{\text {lysMcre }}$ mice the myelin sheath was less damaged by protection of anti-inflammatory AAMs or more efficiently regenerated.

However, since the data show that $M^{\text {lysMcre }}$ macrophages exert anti-inflammatory characteristics, which are beneficial for attenuating the severity of EAE, why there are not more, but less infiltrated macrophages in $\mathrm{MR}^{\mathrm{lys} M c r e}$ to contribute to attenuate the inflammation in spinal cord? A possible explanation is: the EAE is an auto-immune disease, involves different leukocyte types, especially the $T_{h} 1$ and $T_{h} 17$ polarized $T$ lymphocytes. Because macrophage polarization is reversible and tightly depends on the mircoenviroment, in which the macrophages locate, residing of macrophage around the activated $T$ lymphocytes could be "dangerous" that the macrophage polarization strongly affected by cytokine from T lymphocytes, such as INFy, which is well known to skew the macrophage polarization to CAM. This could be also the reason that the less AAM markers expression by infiltrating cells than that by PMs.

\subsection{Generation of new transgenic mice}


I cloned a number of sequences of shGR, shMR and shSirt1 into the newly generated plasmid "FUTG-Agel new". The cloning procedure included three steps: 1) Preparation of oligos of shRNA, 2) Cloning of the oligos into the new plasmid, 3) Amplification of the constructs. By using the new plasmid the duration of shRNA cloning was reduced to 2 days, including sequencing. The following tests with the shGR sequence verified that this plasmid can efficiently knock-down target genes (Figure 17B). And the following functional tests identified that after Dox adiminstration the shGR transfected cells exert similar property compared with GR knockout cells (Figure $21 \mathrm{~A}, \mathrm{~B}$ ). These data imply that the newly generated plasmid is qualified for the inducible and reversible shRNA expression in host cells. According to my western blots I found that the most efficient sequence of shSirt1 was the "seq. 3" (Figure 19B). The protein band of Sirt1 from cells, which were transfected with the "seq.3", vanished almost completely after Doxycycline treatment.

In case of shMR, I found the most efficient sequence of shMR was the "seq.4" (Figure 18B). The protein band of MR from cells, which were transfected with the "seq.4", vanished almost completely after Dox treatment. However, I cound not do functional test after induction of shMR expression like in case of shGR. Because we did not have a suitable mouse cell line for shMR knock-down test, I used the the HEK293 cells, in whicht mouse MR gene was exogenously transfected by pCDNA3 plasmid but does not have any physiological function in those cells. Nonetheless, I still generated lentiviruses with the "seq.4" of shMR and my colleague, Fischer, $\mathrm{H}$., generated transgenic mice with the lentiviruses.

After transferring the viral infected embryos into the oviduct of peseudopregnant female mice, we got 8 offsprings. The flow cytometry data of tail blood of these offsprings (Figure 22A) revealed in the three offsprings, No. 2, No. 5 and No. 8, the shMR construct was expressed by leukocytes. Furthermore, the PCR data (Figure 22B) verified the offsprings 
with successful integration of the lentiviral construct. These data indicate that the new transgenic mice were successfully generated. After breeding, further physiological experiments about MR will be performed.

I generated the lentiviral vector "FUTG-Agel new" that differs from "FH1tUTG", used in Herold et al., 2008, in 1) that all the components are placed in the vector and shRNA cloning sites are modified and 2) the mutation of the last $6 \mathrm{bp}$ of $\mathrm{H} 1$ promoter only guarantees the reading frame by expressing shRNA without any affect on promoter activity (Myslinski et al., 2001). Therefor, the lentiviral vector system "FUTG-Agel new" inherites all the advanced features from the lentiviral vector system "FH1tUTG": 1) all components necessary for inducible shRNA expression are placed in one single vector, which reduces the need to cross-breed several strains of animals; 2) EGFP expression simplified the identification of transgenic offspring, transcriptionally active proviral integrations and controlling for possible mosaicism; 3) Gene knockdown is strictly triggered by administration of Dox, which prevents a lethal knockdown phenotype caused by continuous gene knockout; 4) in vitro, inducibility of the most efficient sequence is very rapid, leading to an almost complete loss of the targeted protein; 5) the sensitivity of the system is high and allows protein knockdown at low Dox concentration, thereby reducing the risk of side effects. Though there was no in vivo test performed, according to relative research reported by Herold et al., 2008, and the highly similar construct in the lentiviral vector, similar in vivo characteristics in knockdown is reasonable highly possible.

Nonetheless, the "FUTG-Agel new" system still has some drawbacks. First, differing from the homologous recombination that the recombinase can be driven by differen cell type specific promoter, like here used LysM promoter, the shRNA expression can only be driven by promoter using RNA polymerase III (Tuschl, 2002; Brummelkamp et al., 2002), in case of this study $\mathrm{H} 1$ promoter. Thus, knockout of a protein in a special cell line in vivo 
is not possible by using the lentiviral system alone and cell transplantation is possibly required. Second, the kinetic of doxycycline is different in organs, for example: as consequence of the lower local Dox concentration in brain (Seibler et al., 2007) a 100 fold administration of doxycycline compared with that in other tissues should be considered, in order to achieve strong protein knockdown, which may leads to a side effect; in muscle the restore of target gene after stopping Dox treatment delays significantly compared with that in the other tissues (Herold et al., 2008). 


\section{References}

Aboul-Enein F, Weiser P, Höftberger R, Lassmann H, Bradl M. (2006). Transient axonal injury in the absence of demyelination: a correlate of clinical disease in acute experimental autoimmune encephalomyelitis. Acta Neuropathol. 2006 Jun;111(6):539-47. (Aboul-Enein et al., 2006)

Albiston AL, Obeyesekere VR, Smith RE, Krozowski ZS. (1994). Cloning and tissue distribution of the human 11 beta-hydroxysteroid dehydrogenase type 2 enzyme. Mol Cell Endocrinol. 1994;105:R11-R17.

Amat R, Solanes G, Giralt M, Villarroya F. (2007). SIRT1 is involved in glucocorticoid-mediated control of uncoupling protein-3 gene transcription. J Biol Chem. 282(47):34066-76. (Amat et al., 2007)

Aoyagi S, Archer TK. (2008). Nicotinamide uncouples hormone-dependent chromatin remodeling from transcription complex assembly. Mol Cell Biol. 28(1):30-9. (Aoyagi and Archer, 2008)

Arai K, Tsigos C, Suzuki Y, Irony I, Karl M, Listwak S, Chrousos GP. (1994). Physiological and molecular aspects of mineralocorticoid receptor action in pseudohypoaldosteronism: a responsiveness test and therapy. J Clin Endocrinol Metab. 79(4):1019-23. (Arai et al., 1994)

Arriza JL, Weinberger C, Cerelli G, Glaser TM, Handelin BL, Housman DE, Evans RM. (1987). Cloning of human mineralocorticoid receptor complementary DNA: structural and functional kinship with the glucocorticoid receptor. Science. ;237(4812):268-75. (Arriza et al., 1987)

Auphan N, DiDonato JA, Rosette C, Helmberg A, Karin M. (1995). Immunosuppression by glucocorticoids: inhibition of NF-kappa B activity through induction of I kappa B synthesis. Science. 1995 Oct 13;270(5234):286-90. (Auphan et al., 1995)

Avital A, Segal M, Richter-Levin G. (2006). Contrasting roles of corticosteroid receptors in hippocampal plasticity. J Neurosci. 2006 Sep 6;26(36):9130-4. (Avital et al., 2006)

Bal-Price A, Brown GC. (2001). Inflammatory neurodegeneration mediated by nitric oxide from activated glia-inhibiting neuronal respiration, causing glutamate 
release and excitotoxicity. $J$ Neurosci. 2001 Sep 1;21(17):6480-91. (Bal-Price et al., 2001)

Beeton C, Garcia A, Chandy KG. (2007). Induction and clinical scoring of chronic-relapsing experimental autoimmune encephalomyelitis. $J$ Vis Exp. 2007;(5):224. (Beeton et al., 2007)

Benson, J.D., Chen, Y.N., Cornell-Kennon, S.A., Dorsch, M., Kim, S., Leszczyniecka, M., Sellers, W.R., Lengauer, C. (2006). Validating cancer drug targets. Nature 441:451-456. (Benson et al., 2006)

Berger S, Wolfer DP, Selbach O, Alter H, Erdmann G, Reichardt HM, Chepkova AN, Welzl H, Haas HL, Lipp HP, Schütz G. (2005). Loss of the limbic mineralocorticoid receptor impairs behavioral plasticity. Proc Natl Acad Sci U S A. 2006 Jan 3;103(1):195-200. (Berger et al., 2005)

Blasi ER, Rocha R, Rudolph AE, Blomme EA, Polly ML, McMahon EG. (2003). Aldosterone/salt induces renal inflammation and fibrosis in hypertensive rats. Kidney Int. 2003 May;63(5):1791-800. (Blasi et al., 2003)

Bledsoe RK, Madauss KP, Holt JA, Apolito CJ, Lambert MH, Pearce KH, Stanley TB, Stewart EL, Trump RP, Willson TM, Williams SP. (2005). A ligand mediated hydrogen bond network required for the activation of the mineralocorticoid receptor. J Biol Chem. 280(35):31283-93. (Bledsoe et al., 2005)

Botto, M., C. A. E. Dell'Agnola, E. M. Bygrave, H. T. Thompson, F. Cook, M. Petry, M. Loos, P. P. Pandolfi, M. J. Walport. 1998. Homozygous C1q deficiency causes glomerulonephritis associated with multiple apoptotic bodies. Nat. Genet.19: 56 (Botto et al., 1998)

Brand MD, Esteves TC. (2005). Physiological functions of the mitochondrial uncoupling proteins UCP2 and UCP3. Cell Metab. 2(2):85-93. (Brand and Esteves, 2005)

Brodie C, Goldreich N, Haiman T, Kazimirsky G. (1998). Functional IL-4 receptors on mouse astrocytes: IL-4 inhibits astrocyte activation and induces NGF secretion. J Neuroimmunol. 1998 Jan;81(1-2):20-30. (Brodie et al., 1998)

Brown GC. (2007). Mechanisms of inflammatory neurodegeneration: iNOS and NADPH oxidase. Biochem Soc Trans. 2007 Nov;35(Pt 5):1119-21. (Brown, 2007) 
Brown NJ. (2008). Aldosterone and vascular inflammation. Hypertension. 51(2):161-7. Epub 2008 Jan 2. Review. (Brown, 2008)

Brummelkamp TR, Bernards R, Agami R. A system for stable expression of short interfering RNAs in mammalian cells. Science. 2002;296:550-553. (Brummelkamp et al., 2002)

Caelles C, González-Sancho JM, Muñoz A. (1997). Nuclear hormone receptor antagonism with AP-1 by inhibition of the JNK pathway. Genes Dev. 1997 Dec 15;11(24):3351-64. (Caelles et al., 1997)

Caglayan E, Stauber B, Collins AR, Lyon CJ, Yin F, Liu J, Rosenkranz S, Erdmann E, Peterson LE, Ross RS, Tangirala RK, Hsueh WA. (2008). Differential roles of cardiomyocyte and macrophages peroxisome proliferator-activated receptor gamma in cardiac fibrosis. Diabetes. 2008 Sep;57(9):2470-9. (Caglayan et al., 2008)

Calò LA, Zaghetto F, Pagnin E, Davis PA, De Mozzi P, Sartorato P, Martire G, Fiore C, Armanini D. (2004). Effect of aldosterone and glycyrrhetinic acid on the protein expression of PAI-1 and p22(phox) in human mononuclear leukocytes. J Clin Endocrinol Metab. 2004 Apr;89(4):1973-6. (Calò et al., 2004)

Canessa CM, Schild L, Buell G, Thorens B, Gautschi I, Horisberger JD, Rossier BC. (1994). Amiloride-sensitive epithelial $\mathrm{Na}+$ channel is made of three homologous subunits. Nature. 367(6462):463-7. (Canessa et al., 1994)

Carmell, M.A. and Hannon, G.J. (2004). RNase III enzymes and the initiation of gene silencing. Nat. Struct. Mol. Biol. 11: 214-218. (Carmell and Hannon, 2004)

Chang, M. K., C. Bergmark, A. Laurila, S. Horkko, K. H. Han, P. Friedman, E. A. Dennis, J. L. Witztum. 1999. Monoclonal antibodies against oxidized low density lipoprotein bind to apoptotic cells and inhibit their phagocytosis by elicited macrophages: evidence that oxidation-specific epitopes mediate macrophage recognition. Proc. Natl. Acad. Sci. USA 96: 6353 (Chang et al., 1999)

Chiu IM, Phatnani H, Kuligowski M, Tapia JC, Carrasco MA, Zhang M, Maniatis T, Carroll MC. (2009). Activation of innate and humoral immunity in the peripheral nervous system of ALS transgenic mice. Proc Natl Acad Sci U S A. 2009 Dec 8;106(49):20960-5. (Chiu et al., 2009)

Colton CA. (1995). Induction of nitric oxide in cultured microglia: evidence for a cytoprotective role. Adv Neuroimmunol. 1995;5(4):491-503. (Colton, 1995) 
Dai Y, Ngo D, Forman LW, Qin DC, Jacob J, Faller DV. (2007). Sirtuin 1 is required for antagonist-induced transcriptional repression of androgen responsive genes by the androgen receptor. Mol Endocrinol. 21(8):1807-21. (Dai et al., 2007)

Dali-Youcef, N., Lagouge, M., Froelich, S., Koehl, C., Schoonjans, K., Auwerx, J. (2007). Sirtuins: the 'magnificent seven', function, metabolism and longevity. Ann Med.39(5):335-45. (Dali-Youcef, 2007)

Datson NA, van der Perk J, de Kloet ER, Vreugdenhil E. (2001). Identification of corticosteroid-responsive genes in rat hippocampus using serial analysis of gene expression. Eur J Neurosci. 2001 Aug;14(4):675-89. (Datson et al., 2001)

Denli, A.M., Tops, B.B., Plasterk, R.H., Ketting, R.F., and Hannon, G.J. (2004). Processing of primary microRNAs by the Microprocessor complex. Nature 432:231-235. (Denli et al., 2004)

Devitt, A., O. D. Moffatt, C. Raykundalia, J. D. Capra, D. L. Simmons, C. D. Gregory. 1998. Human CD14 mediates recognition and phagocytosis of apoptotic cells. Nature 392: 505 (Devitt et al., 1998)

Doench, J.G., Petersen, C.P., Sharp, P.A. (2003). siRNAs can function as miRNAs. Genes 17(4):438-42. (Doench et al., 2003)

Dull, T., Zufferey, R., Kelly, M., Mandel, R.J., Nguyen, M., Trono, D., Naldini, L. (1998). A third-generation lentivirus vector with a conditional packaging system. $J$ Virol. 72(11): 8463-71. (Dull, 1998)

Duvall, E., A. H. Wyllie, R. G. Morris. 1985. Macrophage recognition of cells undergoing programmed cell death (apoptosis). Immunology 56: 351 (Duvall et al., 1985)

Fadok, V. A., D. L. Bratton, D. M. Rose, A. Pearson, R. A. Ezekewitz, P. M. Henson. 2000. A receptor for phosphatidylserine-specific clearance of apoptotic cells. Nature 405: 85 (Fadok et al., 2000)

Fan YY, Kohno M, Hitomi H, Kitada K, Fujisawa Y, Yatabe J, Yatabe M, Felder RA, Ohsaki H, Rafiq K, Sherajee SJ, Noma T, Nishiyama A, Nakano D. (2011). Aldosterone/Mineralocorticoid receptor stimulation induces cellular senescence in the kidney. Endocrinology. 152(2):680-8. (Fan et al., 2011) 
Farias, A. S., C. de la Hoz, F. R. Castro, E. C. Oliveira, J. R. Ribeiro dos Reis, J. S. Silva, F. Langone, L. M. B. Santos. (2007). Nitric oxide and TNFalpha effects in experimental autoimmune encephalomyelitis demyelination. Neuroimmunomodulation 14: 32-38. (Farias et al., 2007)

Fraccarollo D, Galuppo P, Schraut S, Kneitz S, van Rooijen N, Ertl G, Bauersachs J. (2008). Immediate mineralocorticoid receptor blockade improves myocardial infarct healing by modulation of the inflammatory response. Hypertension. 2008 Apr;51(4):905-14. (Fraccarollo et al., 2008)

Frieler RA, Meng $H$, Duan SZ, Berger S, Schütz G, He Y, Xi G, Wang MM, Mortensen RM. (2011). Myeloid-Specific Deletion of the Mineralocorticoid Receptor Reduces Infarct Volume and Alters Inflammation During Cerebral Ischemia. Stroke. 2011 Jan;42(1):179-85. (Frieler et al., 2011)

Fuller, P.J. (1991). The steroid receptor superfamily: mechanisms of diversity. FASEB J. Dec; 5(15):3092-9. (Fuller, 1991)

Geissmann, F., Manz, M.G., Jung, S., Sieweke, M.H., Merad, M., Ley, K. (2010). Development of monocytes, macrophages, and dendritic cells. Science 327:656-661. (Geissmann et al., 2010)

Glaser, S., Anastassiadis, K., and Stewart, A.F. (2005) Current issues in mouse genome engineering. Nat Genet 37: 1187-1193. (Glaser et al., 2005)

Gordon S. (2003). Alternative activation of macrophages. Nat Rev Immunol. 3(1):23-35. (Gordon, 2003)

Gordon, S. (2003). Alternative activation of macrophages. Nat Rev Immunol. 3(1):23-35. Review. (Gordon, 2003)

Goverman, J.M. (2011). Immune Tolerance in Multiple Sclerosis. Immunol Rev. 241(1):228-40. (Goverman, 2011)

Govindan MV, Warriar N. (1998). Reconstitution of the N-terminal transcription activation function of human mineralocorticoid receptor in a defective human glucocorticoid receptor. J Biol Chem. 273(38):24439-47. (Govindan and Warriar, 1998)

Gratchev A, Kzhyshkowska J, Utikal J, Goerdt S. (2005). Interleukin-4 and dexamethasone counterregulate extracellular matrix remodelling and 
phagocytosis in type-2 macrophages. Scand J Immunol. 2005 Jan;61(1):10-7. (Gratchey et al., 2005)

Gregory, R.I., Chendrimada, T.P., Cooch, N., and Shiekhattar, R. (2005). Human RISC couples microRNA biogenesis and posttranscriptional gene silencing. Cell 123: 631-640. (Gregory et al., 2005)

Gregory, R.I., Yan, K.P., Amuthan, G., Chendrimada, T., Doratotaj, B., Cooch, N., and Shiekhattar, R. (2004). The Microprocessor complex mediates the genesis of microRNAs. (Gregory et al., 2004)

Greiss S, Gartner A. (2009). Sirtuin/Sir2 phylogeny, evolutionary consideration and structural conservation. Mol Cells. 28(5):407-15. (Greiss and Gartner, 2009)

Gronemeyer, H, Gustafsson, JA, Laudet, V. (2004). Principles for modulation of the nuclear receptor superfamily. Nat Rev Drug Discov. 3(11):950-64. (Gronemeyer et al., 2004)

Haigis, M.C., Mostoslavsky, R., Haigis, K.M., Fahie, K., Christodoulou, D.C., Murphy, A.J., Valenzuela, D.M., Yancopoulos, G.D., Karow, M., Blander, G., Wolberger, C., Prolla, T.A., Weindruch, R., Alt, F.W., Guarente, L. (2006). SIRT4 inhibits glutamate dehydrogenase and opposes the effects of calorie restriction in pancreatic beta cells. Cell 126(5):941-54. (Haigis et al., 2006)

Han, J., Lee, Y., Yeom, K.H., Kim, Y.K., Jin, H., and Kim, V.N. (2004). The Drosha-DGCR8 complex in primary microRNA processing. Genes \& Dev. 18: 3016-3027. (Han et al., 2004)

Hench PS, Kendall EC, Slocumb CH, Polley HF. (1949). Adrenocortical Hormone in Arthritis : Preliminary Report. Ann Rheum Dis. 1949 Jun;8(2):97-104. (Hench et al., 1949)

HENCH PS, SLOCUMB CH, POLLEY HF, KENDAL EC. (1950). Effect of cortisone and pituitary adrenocorticotropic hormone (ACTH) on rheumatic diseases. J Am Med Assoc. 1950 Dec 16;144(16):1327-35. (Hench et al., 1950)

Herold, M.J., van den Brandt, J., Seibler, J., Reichardt, H.M. (2008). Inducible and reversible gene silencing by stable integration of an shRNA-encoding lentivirus in transgenic rats. Proc Natl Acad Sci USA November 25; 105(47): 18507-18512. (Herold et al., 2008) 
Herrada AA, Contreras FJ, Marini NP, Amador CA, González PA, Cortés CM, Riedel CA, Carvajal CA, Figueroa F, Michea LF, Fardella CE, Kalergis AM. (2010). Aldosterone promotes autoimmune damage by enhancing Th17-mediated immunity. J Immunol. 2010 Jan 1;184(1):191-202. (Herrada et al., 2010)

Horisberger JD, Lemas V, Kraehenbühl JP, Rossier BC. (1991). Structure-function relationship of Na,K-ATPase. Annu Rev Physiol. 53:565-84. (Horisberger et al., 1991)

Hsueh WA, Do YS, Jeyaseelan R. (1998). Angiotensin II and cardiac remodeling. Mt Sinai J Med. 65(2):104-7. Review. (Hsueh et al., 1998)

Hutvagner, G. and Zamore, P.D. (2002). A microRNA in a multiple-turnover RNAi enzyme complex. Science 297, 2056-2060. (Hutvagner and Zamore, 2002)

Iglarz M, Touyz RM, Viel EC, Paradis P, Amiri F, Diep QN, Schiffrin EL. (2003). Peroxisome proliferator-activated receptor-alpha and receptor-gamma activators prevent cardiac fibrosis in mineralocorticoid-dependent hypertension. Hypertension. 2003 Oct;42(4):737-43. (Iglarz et al., 2003)

Kim, V.N. (2005). MicroRNA biogenesis: Coordinated cropping and dicing. Nat. Rev. Mol. Cell Biol. 6: 376-385. (Kim, 2005)

Kitamura Y, Taniguchi T, Kimura H, Nomura Y, Gebicke-Haerter PJ. (2000). Interleukin-4-inhibited mRNA expression in mixed rat glial and in isolated microglial cultures. J Neuroimmunol. 2000 Jul 1;106(1-2):95-104. (Kitamura et al. 2000)

Knowles RG, Moncada S (1994). "Nitric oxide synthases in mammals". Biochem. J. 298 (Pt 2): 249-258. (Knowles and Moncada, 1994)

Kraft AD, Harry GJ. (2011). Features of microglia and neuroinflammation relevant to environmental exposure and neurotoxicity. Int $J$ Environ Res Public Health. 2011 Jul;8(7):2980-3018. (Kraft and Harry, 2011)

Landthaler, M., Yalcin, A., and Tuschl, T. 2004. The human DiGeorge syndrome critical region gene 8 and Its $D$. melanogaster homolog are required for miRNA biogenesis. Curr. Biol. 14: 2162-2167. (Landthaler et al., 2004) 
Lassmann H, Brück W, Lucchinetti CF. (2007). The immunopathology of multiple sclerosis: an overview. Brain Pathol. 2007 Apr;17(2):210-8. Review. (Lassmann et al., 2007)

Lee, Y., Ahn, D., Han, J., Choi, H., Kim, J., Yim, J., Lee, J., Provost, P., Radmark, O., Kim, S., et al. (2003). The nuclear RNase III Drosha initiates microRNA processing. Nature 425: 415-419. (Lee et al., 2003)

Leibovitz E, Ebrahimian T, Paradis P, Schiffrin EL. (2009). Aldosterone induces arterial stiffness in absence of oxidative stress and endothelial dysfunction. $J$ Hypertens. 27(11):2192-200. (Leibovitz et al., 2009)

Lewis, B.P., Burge, C.B., and Bartel, D.P. (2005). Conserved seed pairing, often flanked by adenosines, indicates that thousands of human genes are microRNA targets. Cell 120: 15-20. (Lewis et al., 2005)

Li Y, Suino K, Daugherty J, Xu HE. (2005). Structural and biochemical mechanisms for the specificity of hormone binding and coactivator assembly by mineralocorticoid receptor. Mol Cell. 19(3):367-80. (Li et al., 2005)

Lijnen P, Petrov V. (1999). Antagonism of the renin-angiotensin-aldosterone system and collagen metabolism in cardiac fibroblasts. Methods Find Exp Clin Pharmacol. 21(3):215-27. (Lijnen et al., 1999)

Lim HY, Müller N, Herold MJ, van den Brandt J, Reichardt HM. (2007). Glucocorticoids exert opposing effects on macrophages function dependent on their concentration. Immunology. 2007 Sep;122(1):47-53. (Lim et al., 2007)

Lin JN, Lin VC, Rau KM, Shieh PC, Kuo DH, Shieh JC, Chen WJ, Tsai SC, Way TD. (2010). Resveratrol modulates tumor cell proliferation and protein translation via SIRT1-dependent AMPK activation. J Agric Food Chem. 58(3):1584-92. (Lin et al., 2010)

Luciani, M. F., G. Chimini. 1996. The ATP binding cassette transporter, ABC1, is required for the engulfment of corpses generated by apoptotic cell death. EMBO J. 15: 226 (Luciani et al., 1996)

Luciw, P.A. (1996). Human immunodeficiency viruses and their replication, p. 1881-1975. In B.N. Fields, D.M. Knipe, P.M. Howley, R.M. Chanock, J.L. Melnick, T.P. Monath, B. Roizman, and S.E. Straus (ed.), Fields virology, $3^{\text {rd }}$ ed. (Luciw, 1996) 
Lui, Y., Cousin, J.M., Hughes, J., Van Damme, J., Seckl, J.R., Haslett, C., Dransfield, I., Savill, J., Rossi A.G. (1999) Glucocorticoids promote non-phlogistic phagocytosis of apoptotic leukocytes. Journal of Immunology, 162, 3639 3646. (Lui et al., 1999)

Luisi BF, Xu WX, Otwinowski Z, Freedman LP, Yamamoto KR, Sigler PB. (1991). Crystallographic analysis of the interaction of the glucocorticoid receptor with DNA. Nature. 352(6335):497-505. (Luisi et al., 1991)

Lund, E., Guttinger, S., Calado, A., Dahlberg, J.E., and Kutay, U. 2004. Nuclear export of microRNA precursors. Science 303: 95-98. (Lund et al., 2004)

Lyons A, Downer EJ, Crotty S, Nolan YM, Mills KH, Lynch MA. (2007). CD200 ligand receptor interaction modulates microglial activation in vivo and in vitro: a role for IL-4. J Neurosci. 2007 Aug 1;27(31):8309-13. (Lyons et al., 2007)

Machaness, G.B. (1964). The immunological basis of acquired cellular resistance. J.Exp.Med. 120: 105. (Machaness, 1964)

Mangelsdorf, D.J., Thummel, C., Beato, M., Herrlich, P., Schütz, G., Umesono, K., Blumberg, B., Kastner, P., Mark, M., Chambon, P., Evans, R.M. (1995). The nuclear receptor superfamily: the second decade. Cell 83:835-839. (Mangelsdorf et al., 1995)

Mantovani A, Sica A, Sozzani S, Allavena P, Vecchi A, Locati M. (2004). The chemokine system in diverse forms of macrophage activation and polarization. Trends Immunol. 2004 Dec;25(12):677-86. (Mantovani et al., 2004)

Mantovani A, Sozzani S, Locati M, Allavena P, Sica A. (2002). Macrophage polarization: tumor-associated macrophages as a paradigm for polarized M2 mononuclear phagocytes. Trends Immunol. 2002 Nov;23(11):549-55. (Mantovani et al., 2002)

Mantovani A, Sozzani S, Locati M, Allavena P, Sica A. (2002). Macrophage polarization: tumor-associated macrophages as a paradigm for polarized M2 mononuclear phagocytes. Trends Immunol. 2002 Nov;23(11):549-55. (Mantovani et al., 2002)

Merrill JE, Ignarro LJ, Sherman MP, Melinek J, Lane TE. (1993). Microglial cell cytotoxicity of oligodendrocytes is mediated through nitric oxide. J Immunol. 1993 Aug 15;151(4):2132-41. (Merrill et al., 1993) 
Mevorach, D., J. O. Mascarenhas, D. Gershov, K. B. Elkon. 1998. Complement-dependent clearance of apoptotic cells by human macrophages. $J$. Exp. Med. 188:2313 (Mevorach et al., 1998)

Miesfeld R, Okret S, Wikström AC, Wrange O, Gustafsson JA, Yamamoto KR. (1984). Characterization of a steroid hormone receptor gene and mRNA in wild-type and mutant cells. Nature. 1984 Dec 20-1985 Jan 2;312(5996):779-81. (Miesfeld et al., 1984)

Milligan, N. M., R. Newcombe, D. A. Compston. (1987). A double-blind controlled trial of high dose methylprednisolone in patients with multiple sclerosis: 1. Clinical effects. J. Neurol. Neurosurg. Psychiatry 50: 511-516. (Milligan et al., 1987)

Moore, R.L., Dai, Y., Faller, D.V. (2012). Sirtuin 1(SIRT1) and steroid hormone receptor activity in cancer. J Endocrinol. 213(1):37-48. (Moore et al., 2012)

Moraes LA, Paul-Clark MJ, Rickman A, Flower RJ, Goulding NJ, Perretti M. (2005). Ligand-specific glucocorticoid receptor activation in human platelets. Blood. 106(13):4167-75. (Moraes et al., 2005)

Mosser DM. (2003). The many faces of macrophages activation. J Leukoc Biol. 73(2):209-12. Review. (Mosser, 2003)

Muzio L, Martino G, Furlan R. (2007). Multifaceted aspects of inflammation in multiple sclerosis: the role of microglia. $J$ Neuroimmunol. 2007 Nov;191(1-2):39-44. (Muzio et al., 2007)

Myslinski E, Amé JC, Krol A, Carbon P. (2001). An unusually compact external promoter for RNA polymerase III transcription of the human H1RNA gene. Nucleic Acids Res. 2001 Jun 15;29(12):2502-9. (Myslinski et al., 2001)

Neumann H, Kotter MR, Franklin RJ. (2009). debris clearence by microglia: an essential link between degeneration and regeneration. Brain. 2009 Feb;132(Pt 2):288-95.

Nielsen M.J., Madsen M., Moller H.J., Moestrup S.K. (2006). The macrophage scavenger receptor CD163: endocytic properties of cytoplasmic tail variants. J. Leukoc. Biol. 79:837-845. (Nielsen et al., 2006)

Nishimura H, Ito Y, Mizuno M, Tanaka A, Morita Y, Maruyama S, Yuzawa Y, Matsuo S. (2008). Mineralocorticoid receptor blockade ameliorates peritoneal 
fibrosis in new rat peritonitis model. Am J Physiol Renal Physiol. 2008 May;294(5):F1084-93. (Nishimura et al., 2008)

Odegaard JI, Ricardo-Gonzalez RR, Goforth $\mathrm{MH}$, Morel CR, Subramanian V, Mukundan L, Red Eagle A, Vats D, Brombacher F, Ferrante AW, Chawla A. (2007). Macrophage-specific PPARgamma controls alternative activation and improves insulin resistance. Nature. 2007 Jun 28;447(7148):1116-20. (Odegaard et al., 2007)

Ogawa S, Lozach J, Benner C, Pascual G, Tangirala RK, Westin S, Hoffmann A, Subramaniam S, David M, Rosenfeld MG, Glass CK. (2005). Molecular determinants of crosstalk between nuclear receptors and toll-like receptors. Cell. 2005 Sep 9;122(5):707-21. (Ogawa et al., 2005)

Ogawa S., Lozach J., Benner C., Pascual G, Rajendra K. Tangirala, Stefan Westin, Alexander Hoffmann, Shankar Subramaniam, Michael David, Michael G. Rosenfeld, Christopher K. Glass. (2005). Molecular Determinants of Crosstalk between Nuclear Receptors and Toll-like Receptors Mediating Counter-regulation of Inflammatory Responses. Cell. 2005 September 9; 122(5): 707-721. doi: 10.1016/j.cell.2005.06.029 (Ogawa et al., 2005)

O'Malley, B. (1990). The steroid receptor superfamily: more excitement predicted for the future. Mol. Endocrinol. 4:363-369. (O'Malley, 1990)

Pascual-Le Tallec L, Lombès M. (2005). The mineralocorticoid receptor: a journey exploring its diversity and specificity of action. Mol Endocrinol. 19(9):2211-21. (Pascual-Le et al., 2005)

Perissi V, Rosenfeld MG. (2005). Controlling nuclear receptors: the circular logic of cofactor cycles. Nat Rev Mol Cell Biol. 6(7):542-54. (Perissi et al., 2005)

Pippal JB, Fuller PJ. (2008). Structure-function relationships in the mineralocorticoid receptor. J Mol Endocrinol. 41(6):405-13. Review. (Pippal and Fuller 2008)

Platt, N., H. Suzuki, Y. Kurihara, T. Kodama, S. Gordon. 1996. Role for the class A macrophage scavenger receptor in the phagocytosis of apoptotic thymocytes in vitro. Proc. Natl. Acad. Sci. USA 93: 12456 (Platt et al., 1996)

Pocock JM, Kettenmann H. (2007). Neurotransmitter receptors on microglia. Trends Neurosci. 2007 Oct;30(10):527-35. (Pocock et al., 2007) 
Popov VM, Wang C, Shirley LA, Rosenberg A, Li S, Nevalainen M, Fu M, Pestell RG. (2007). The functional significance of nuclear receptor acetylation. Steroids. 72(2):221-30. (Popov et al., 2007)

Pu Q, Neves MF, Virdis A, Touyz RM, Schiffrin EL. (2003). Endothelin antagonism on aldosterone-induced oxidative stress and vascular remodeling. Hypertension. 42(1):49-55. (Pu et al., 2003)

Ramírez F, Fowell DJ, Puklavec M, Simmonds S, Mason D. (1996). Glucocorticoids promote a TH2 cytokine response by CD4+ T cells in vitro. $J$ Immunol. 1996 Apr 1;156(7):2406-12. (Ramírez et al., 1996)

Reichardt HM, Kaestner KH, Tuckermann J, Kretz O, Wessely O, Bock R, Gass P, Schmid W, Herrlich P, Angel P, Schütz G. (1998). DNA binding of the glucocorticoid receptor is not essential for survival. Cell. 1998 May 15;93(4):531-41. (Reichardt et al., 1998)

Reichardt HM, Tuckermann JP, Göttlicher M, Vujic M, Weih F, Angel P, Herrlich P, Schütz G. (2001). Repression of inflammatory responses in the absence of DNA binding by the glucocorticoid receptor. EMBO J.2001 Dec 17;20(24):7168-73. (Reichardt et al., 2001)

Reichardt, H. M., R. Gold, F. Lühder. (2006). Glucocorticoids in multiple sclerosis and experimental autoimmune encephalomyelitis. Expert Rev. Neurother. 6:1657-1670. (Reichardt et al., 2006)

Rickard AJ, Morgan J, Tesch G, Funder JW, Fuller PJ, Young MJ. (2009). Deletion of mineralocorticoid receptors from macrophages protects against deoxycorticosterone/salt-induced cardiac fibrosis and increased blood pressure. Hypertension. 2009 Sep;54(3):537-43. (Richard et al., 2009)

Rickard AJ, Young MJ. (2009). Corticosteroid receptors, macrophages and cardiovascular disease. J Mol Endocrinol. 2009 Jun;42(6):449-59. (Richard and Young, 2009)

Rivers TM, Sprunt DH, Berry GP. (1933). OBSERVATIONS ON ATTEMPTS TO PRODUCE ACUTE DISSEMINATED ENCEPHALOMYELITIS IN MONKEYS. J Exp Med. 1933 Jun 30;58(1):39-53. (Rivers et al., 1933)

Rocha R, Rudolph AE, Frierdich GE, Nachowiak DA, Kekec BK, Blomme EA, McMahon EG, Delyani JA. (2002). Aldosterone induces a vascular 
inflammatory phenotype in the rat heart. Am J Physiol Heart Circ Physiol. 2002 Nov;283(5):H1802-10. (Rocha et al., 2002)

Rupprecht R, Arriza JL, Spengler D, Reul JM, Evans RM, Holsboer F, Damm K. (1993). Transactivation and synergistic properties of the mineralocorticoid receptor: relation-ship to the glucocorticoid receptor. $\mathrm{Mol}$ Endocrinol. 7(4):597-603. (Rupperecht et al., 1993)

Rutschman R, Lang R, Hesse M, Ihle JN, Wynn TA, Murray PJ. (2001). Stat6-dependent substrate depletion regulates nitric oxide production. $J$ Immunol. 166(4):2173-7. (Rutschman et al., 2001)

Savill, J. S., I. Dransfield, N. Hogg, C. Haslett. 1990. Vitronectin receptor-mediated phagocytosis of cells undergoing apoptosis. Nature 342: 170 (Savill et al., 1990)

Savill, J. S., N. Hogg, Y. Ren, C. Haslett. 1992. Thrombospondin cooperates with CD36 and the vitronectin receptor in macrophage recognition of neutrophils undergoing apoptosis. J. Clin. Invest. 90: 1513 (Savill et al., 1992)

Schebesch C, Kodelja V, Müller C, Hakij N, Bisson S, Orfanos CE, Goerdt S. (1997). Alternatively activated macrophages actively inhibit proliferation of peripheral blood lymphocytes and CD4+ $\mathrm{T}$ cells in vitro. Immunology. 92(4):478-86. (Schebesch et al., 1997)

Schenk S, McCurdy CE, Philp A, Chen MZ, Holliday MJ, Bandyopadhyay GK, Osborn O, Baar K, Olefsky JM. (2011). Sirt1 enhances skeletal muscle insulin sensitivity in mice during caloric restriction. J Clin Invest. 121(11):4281-8. (Schenk et al., 2011)

Schmidt BM, Sammer U, Fleischmann I, Schlaich M, Delles C, Schmieder RE. (2006). Rapid nongenomic effects of aldosterone on the renal vasculature in humans. Hypertension. 47(4):650-5. (Schmidt et al., 2006)

Schreiner B, Heppner FL, Becher B. (2009). Modeling multiple sclerosis in laboratory animals. Semin Immunopathol. 2009 Nov;31(4):479-95. (Schreiner et al., 2009)

Schwartz, B. R., A. Karsan, T. Bombeli, J. M. Harlan. 1999. A novel $\beta_{1}$ integrin-dependent mechanism of leukocyte adherence to apoptotic cells. $J$. Immunol. 162:4842 (Schwartz et al., 1999) 
Schweingruber N, Haine A, Tiede K, Karabinskaya A, van den Brandt J, Wüst S, Metselaar JM, Gold R, Tuckermann JP, Reichardt HM, Lühder F. (2011). Liposomal Encapsulation of Glucocorticoids Alters Their Mode of Action in the Treatment of Experimental Autoimmune Encephalomyelitis. J Immunol. 2011 October 187 (8): 4310-4318 (Schweingruber et al., 2011)

Seibler, J., Kleinridders, A., Küter-Luks, B., Niehaves, S., Brüning, J.C., Schwenk, F. (2007). Reversible gene knockdown in mice using a tight, inducible shRNA expressing system. Nucleic Acids Research Vol. 35 (7): e54. (Seibler et al., 2007)

Siffrin V, Brandt AU, Herz J, Zipp F. (2007). New insights into adaptive immunity in chronic neuroinflammation. Adv Immunol. 2007;96:1-40. (Siffrin et al., 2007)

Silke A., Valdete M., Anita B., Markus M. W., Frank G., and Peter B. (2004). PPAR-y agonists inhibit toll-like receptor-mediated activation of dendritic cells via the MAP kinase and NF-kB pathways. Blood December 1, 2005 106: 123888-3894 (Silke et al., 2004)

Steinman L, Zamvil SS. (2006). How to successfully apply animal studies in experimental allergic encephalomyelitis to research on multiple sclerosis. Ann Neurol. 2006 Jul;60(1):12-21. (Steinman et al., 2006)

Stewart PM, Mason JI. (1995). Cortisol to cortisone: glucocorticoid to mineralocorticoid. Steroids. 60(1):143-6. (Stewart and Mason et al., 1995)

Szymczak, A.L., Vignali, D.A. (2005). Development of 2A peptide-based strategies in the design of multicistronic vectors. Expert Opin Biol Ther.5:627-638. (Szymczak and Vignali, 2005)

Takeda Y. (2004). Pleiotropic Actions of Aldosterone and the Effects of Eplerenone, a Selective Mineralocorticoid Receptor Antagonist. Hypertens Res. 2004 Nov;27(11):781-9. (Takeda, 2004)

Tanaka J, Fujita H, Matsuda S, Toku K, Sakanaka M, Maeda N. (1997). Glucocorticoid- and mineralocorticoid receptors in microglial cells: the two receptors mediate differential effects of corticosteroids. Glia. 1997 May;20(1):23-37. (Tanaka et al., 1997)

Thiel VE, Audus KL. (2001). Nitric oxide and blood-brain barrier integrity. Antioxid Redox Signal. 2001 Apr;3(2):273-8. (Thiel and Audus, 2001) 
Tuckermann JP, Reichardt HM, Arribas R, Richter KH, Schütz G, Angel P. (1999). The DNA binding-independent function of the glucocorticoid receptor mediates repression of AP-1-dependent genes in skin. J Cell Biol. 1999 Dec 27;147(7):1365-70. (Tuckermann et al., 1999)

Tuschl T. Expanding small RNA interference. Nat Biotechnol. 2002;20:446-448. (Tuschl, 2002)

Usher MG, Duan SZ, Ivaschenko CY, Frieler RA, Berger S, Schütz G, Lumeng CN, Mortensen RM. (2010). Myeloid mineralocorticoid receptor controls macrophage polarization and cardiovascular hypertrophy and remodeling in mice. J Clin Invest. 2010 Sep;120(9):3350-64. (Usher et al., 2010)

Usher MG, Duan SZ, Ivaschenko CY, Frieler RA, Berger S, Schütz G, Lumeng CN, Mortensen RM. (2010). Myeloid mineralocorticoid receptor controls macrophage polarization and cardiovascular hypertrophy and remodeling in mice. J Clin Invest. 2010 Sep;120(9):3350-64. (Usher et al., 2010)

Valencia-Sanchez, M.A., Liu, J., Hannon, G.J., Parker, R. (2006). Control of translation and mRNA degradation by miRNAs and siRNAs. Genes Dev. 20(5):515-24. (Valencia-Sanchez et al., 2006)

van Rossum D, Hilbert S, Strassenburg S, Hanisch UK, Brück W. (2008). Myelin-phagocytosing macrophages in isolated sciatic and optic nerves reveal a unique reactive phenotype. Glia. 2008 Feb;56(3):271-83. (van Rossum et al., 2008)

Viengchareun S, Le Menuet D, Martinerie L, Munier M, Pascual-Le Tallec L, Lombès M. (2007). The mineralocorticoid receptor: insights into its molecular and (patho) physiological biology. Nucl Recept Signal. 5:e012. (Viengchareun et al., 2007)

Wang D, Müller N, McPherson KG, Reichardt HM. (2006). Glucocorticoids engage different signal transduction pathways to induce apoptosis in thymocytes and mature T cells. J Immunol. 2006 Feb 1;176(3):1695-702. (Wang et al., 2006)

Wang Y, Wang YP, Zheng G, Lee VW, Ouyang L, Chang DH, Mahajan D, Coombs J, Wang YM, Alexander SI, Harris DC. (2007). Ex vivo programmed macrophages ameliorate experimental chronic inflammatory renal disease. Kidney Int. 2007 Aug;72(3):290-9. (Wang et al., 2007) 
WARD LE, SLOCUMB CH, POLLEY HF, LOWMAN EW, HENCH PS. (1951). Clinical effects of cortisone administered orally to 100 patients with rheumatoid arthritis. Ann Rheum Dis. 1951 Dec;10(4):477-84. (Ward et al., 1951)

Wu G, Morris SM (November 1998). "Arginine metabolism: nitric oxide and beyond". The Biochemical journal. 336 ( Pt 1): 1-17. (Wu and Morris, 1998)

Wüst S, van den Brandt J, Tischner D, Kleiman A, Tuckermann JP, Gold R, Lühder F, Reichardt HM. (2008). Peripheral T Cells Are the Therapeutic Targets of Glucocorticoids in Experimental Autoimmune Encephalomyelitis. J Immunol. 2008 Jun 15;180(12):8434-43. (Wüst et al., 2008)

Yamamoto, H., Schoonjans, K., Auwerx, J. (2007). Sirtuin functions in health and disease. Mol Endocrinol. 21(8):1745-55. (Yamamoto, 2006)

Yang, T., Fu, M., Pestell, R., Sauve, A.A. (2006). SIRT1 and endocrine signaling. Trends Endocrinol Metab. 17(5):186-91. (Yang, 2006)

Yao Y, Li H, Gu Y, Davidson NE, Zhou Q. (2010). Inhibition of SIRT1 deacetylase suppresses estrogen receptor signaling. Carcinogenesis. 31(3):382-7. (Yao et al., 2010)

Yee, J.K., Miyanohara, A., LaPorte, P., Bouic, K., Burns, J.C., Friedmann, T. (1994). A general method for the generation of high-titer, pantropic retroviral vectors: highly efficient infection of primary hepatocytes. Proc Natl Acad Sci USA. 91(20):9564-8. (Yee et al., 1994)

Yi, R., Qin, Y., Macara, I.G., and Cullen, B.R. (2003). Exportin-5 mediates the nuclear export of pre-microRNAs and short hairpin RNAs. Genes \&x Dev. 17:3011-3016. (Yi et al., 2003)

Young MJ, Moussa L, Dilley R, Funder JW. (2003). Early inflammatory responses in experimental cardiac hypertrophy and fibrosis: effects of 11 beta-hydroxysteroid dehydrogenase inactivation. Endocrinology. 2003 Mar;144(3):1121-5. (Young et al., 2003)

Yuan J, Minter-Dykhouse K, Lou Z. (2009). A c-Myc-SIRT1 feedback loop regulates cell growth and transformation. J Cell Biol. 185(2).203-11. (Yuan et al., 2009) 
Zeng, Y., Yi, R., and Cullen, B.R. (2003). MicroRNAs and small interfering RNAs can inhibit mRNA expression by similar mechanisms. Proc. Natl. Acad. Sci. USA 100, 9779-9784. (Zeng et al., 2003)

Zhang D, Li S, Cruz P, Kone BC. (2009). Sirtuin 1 functionally and physically interacts with disrupter of telomeric silencing-1 to regulate alpha-ENac transcription in collecting duct. J Biol Chem. 284(31).20917-26. (Zhang et al., 2009) 


\section{Acknowledgements}

First of all I must appreciate my supervisor Prof. Dr. Holger Reichardt for his guidance and support throughout my thesis project. I am thankful for offering me the opportunity in his laboratory and for his scientific expertise, patience and the opportunity to discuss ideas open-mindedly.

I must also appreciate my thesis committee members Prof. Dr. Lutz Walter and Prof. Dr. Steven Johnsen for their interest and advices throughout my project. I must also appreciate my colleagues: Nils Schweingruber, for his great help in EAE experiments and advices; Henrike Fischer, for her work in generating transgenic mice; Elena Nachname, for her work in analysis of histology.

I must also give many thanks to our co-operation partner: Dr. Fred Lühder at the IMSF in Göttingen.

I thank our technicians, Amina Bassibas and Julian Koch, for their assistance on many stressful works and for relieving me of many tasks, as well as the stall at the ENI and ZTE.

I thank Rosemarie Döhne and Ingrid Teuteberg for guiding me through the jungle of bureaucracy. And many special thanks go to the rest of the AG Reichardt for a great time.

Never to forget, I must thank my parents for unconditional support, Yun Wan for everything and the rest of my family. 